\title{
Antioxidant-conjugated 1,2,4-Triazolo[4,3-a]pyrazin-3-one Derivatives: Highly Potent and Selective Human A2A Adenosine Receptor Antagonists Possessing Protective Efficacy in Neuropathic Pain \\ Matteo Falsini, Daniela Catarzi, Flavia Varano, Costanza Ceni, Diego Dal Ben, Gabriella Marucci, Michela Buccioni, Rosaria Volpini, Lorenzo Di Cesare Mannelli, Elena Lucarini, Carla Ghelardini, Gianluca Bartolucci, Marta Menicatti, and Vittoria Colotta
}

J. Med. Chem., Just Accepted Manuscript • DOI: 10.1021/acs.jmedchem.9b00778 • Publication Date (Web): 27 Aug 2019

Downloaded from pubs.acs.org on September 2, 2019

\section{Just Accepted}

"Just Accepted" manuscripts have been peer-reviewed and accepted for publication. They are posted online prior to technical editing, formatting for publication and author proofing. The American Chemical Society provides "Just Accepted" as a service to the research community to expedite the dissemination of scientific material as soon as possible after acceptance. "Just Accepted" manuscripts appear in full in PDF format accompanied by an HTML abstract. "Just Accepted" manuscripts have been fully peer reviewed, but should not be considered the official version of record. They are citable by the Digital Object Identifier (DOI®). "Just Accepted" is an optional service offered to authors. Therefore, the "Just Accepted" Web site may not include all articles that will be published in the journal. After a manuscript is technically edited and formatted, it will be removed from the "Just Accepted" Web site and published as an ASAP article. Note that technical editing may introduce minor changes to the manuscript text and/or graphics which could affect content, and all legal disclaimers and ethical guidelines that apply to the journal pertain. ACS cannot be held responsible for errors or consequences arising from the use of information contained in these "Just Accepted" manuscripts. 


\title{
Antioxidant-conjugated 1,2,4-Triazolo[4,3-a]pyrazin-3-one Derivatives: Highly Potent and Selective Human $\mathbf{A}_{2 \mathrm{~A}}$ Adenosine Receptor Antagonists Possessing Protective Efficacy in Neuropathic Pain
}

\author{
Matteo Falsini, ${ }^{\text {a }}$ Daniela Catarzi, ${ }^{\text {a }}$ Flavia Varano, ${ }^{a}$ Costanza Ceni, ${ }^{a}$ Diego Dal Ben, ${ }^{\mathrm{b}}$ Gabriella \\ Marucci, ${ }^{\mathrm{b}}$ Michela Buccioni, ${ }^{\mathrm{b}}$ Rosaria Volpini, ${ }^{\mathrm{b}}$ Lorenzo Di Cesare Mannelli, ${ }^{\mathrm{c}}$ Elena Lucarini, ${ }^{\mathrm{c}}$ \\ Carla Ghelardini, ${ }^{\mathrm{c}}$ Gianluca Bartolucci, ${ }^{\mathrm{a}}$ Marta Menicatti, ${ }^{\mathrm{a}}$ Vittoria Colotta ${ }^{\mathrm{a}}$ \\ ${ }^{a}$ Dipartimento di Neuroscienze, Psicologia, Area del Farmaco e Salute del Bambino, Sezione di Farmaceutica e \\ Nutraceutica, Università degli Studi di Firenze, Via Ugo Schiff, 6, 50019 Sesto Fiorentino, Italy. \\ ${ }^{b}$ Scuola di Scienze del Farmaco e dei Prodotti della Salute, Università degli Studi di Camerino, via S. Agostino 1, \\ 62032 Camerino (MC), Italy. \\ ${ }^{c}$ Dipartimento di Neuroscienze, Psicologia, Area del Farmaco e Salute del Bambino, Sezione di Farmacologia e \\ Tossicologia, Università degli Studi di Firenze, Viale Pieraccini 6, 50139 Firenze, Italy.
}

Key words: $G$ protein-coupled receptors, $A_{2 A}$ adenosine receptor antagonists, 1,2,4-triazolo[4,3a]pyrazin-3-one, neuropathic pain, ligand-adenosine receptor modeling studies. 


\begin{abstract}
New 8-amino-6-aryl-2-phenyl-1,2,4-triazolo[4,3-a]pyrazine-3-ones were designed to obtain dual antioxidant-human $\mathrm{A}_{2 \mathrm{~A}}$ adenosine receptor $(\mathrm{hA} 2 \mathrm{AR}$ ) antagonists. Two sets of compounds were synthesized, the first featuring phenol rings at the 6-position, the second bearing the lipoyl and 4hydroxy-3,5-di-terbut-benzoyl residues appended by different linkers on the 6-phenyl ring. Several new triazolopyrazines (1-21) were potent and selective $\mathrm{hA}_{2 \mathrm{~A}} \mathrm{AR}$ antagonists $\left(\mathrm{K}_{\mathrm{i}}=0.17-54.5 \mathrm{nM}\right)$. Compounds 11, 15 and 21, featuring antioxidant moieties, and compound 12, lacking the antioxidant functionality, reduced oxaliplatin-induced toxicity in microglia cells, the most active being the lipoyl-derivative $\mathbf{1 5}$ and the (4-hydroxy-3,5-di-tert-butyl)phenyl- analogue $\mathbf{2 1}$ which were effective in reducing the oxygen free radical level. The lipoyl-derivative $\mathbf{1 5}$ was also able to revert oxaliplatin-induced neuropathy in mouse. In vivo efficacy of $\mathbf{1 5}$ makes it a promising neuroprotective agent in oxidative stress-related diseases.
\end{abstract}




\section{INTRODUCTION}

The endogenous nucleoside adenosine affects many pathophysiological conditions through activation of $G$ protein-coupled receptors classified as $A_{1}, A_{2 A}, A_{2 B}$ and $A_{3}$ receptors. $A_{2 A} A R$ stimulation increases adenylate cyclase activity and cAMP production, thus activating protein kinase A and the mitogen-activated protein kinases p38, ERK1/ 2 and JNK1/2. ${ }^{1,2}$

The $A_{2 A} A R$ subtype is expressed in the central nervous system (CNS) showing the greatest density in the striatum, olfactory tubercle and nucleus accumbens while lower levels are present in the cortex and hippocampus. In periphery, the $\mathrm{A}_{2 \mathrm{~A}} \mathrm{AR}$ is abundant in heart, lung, blood vessels and in the immune system.

The $\mathrm{A}_{2 \mathrm{~A}}$ AR plays a key role in the regulation of inflammatory processes both in the CNS and in periphery. ${ }^{1-4}$ At peripheral level, it activates an anti-inflammatory cascade through a reduced functionality of the immune system cells and inflammatory cells. In particular, the $\mathrm{A}_{2 \mathrm{~A}} \mathrm{AR}$ decreases the functions of neutrophils, T cells activation, migration of mast cells and macrophages and the release of cytokines. The $\mathrm{A}_{2 \mathrm{~A}} \mathrm{AR}$-mediated immune suppressive effect accounts for the profitable role of the $\mathrm{A}_{2 \mathrm{~A}}$ stimulation in inflammatory processes. However, in some types of solid cancer, in which hypoxia enhances adenosine concentration, this effect can exacerbate. Hence, suppression of the immune responses in the tumor microenvironment, in particular those $\mathrm{T}$ cellmediated, produces deleterious effects since protects cancer cells from death, thus promoting tumor growth and metastasis. As a consequence, $\mathrm{A}_{2 \mathrm{~A}} \mathrm{AR}$ antagonists, being effective in removing the adenosine-mediated immune escape, are considered as novel therapeutic agents in the immunotherapy of cancer. ${ }^{5}$

In the CNS, $A_{2 A} A R$ activation can exert opposite effects to the peripheral ones. The $A_{2 A} A R$ is present on both pre- and post-synaptic neurons and also in glial cells where it stimulates proinflammatory functions, particularly by inducing activation of both microglia and astrocytes in proinflammatory phenotype. ${ }^{1,4}$ Under physiological conditions, the $\mathrm{A}_{2 \mathrm{~A}} \mathrm{AR}$ expression in microglia and 
astrocyte is usually low while it increases after brain insults, nerve injury and inflammatory signals. ${ }^{6,7}$ Induction of glial $\mathrm{A}_{2 \mathrm{~A}} \mathrm{AR}$ expression takes part in an important feed-forward mechanism to locally control neuroinflammatory responses in the brain. ${ }^{8,9}$ Activation of $\mathrm{A}_{2 \mathrm{~A}} \mathrm{ARs}$ in microglia has mixed effects on proliferation of these cells, and clearly shows a facilitating action on the release of pro-inflammatory cytokines, such as IL-1 $\beta$, TNF, IL-2 and IL-6, and of ROS, all associated with neuronal damage occurring in Parkinson's (PD) and Alzheimer's (AD) diseases. ${ }^{9}$ Consequently, the blockade of the $\mathrm{A}_{2 \mathrm{~A}} \mathrm{AR}$ by antagonists induces neuroprotection in these CNS disorders in which neuroinflammatory and oxidative processes play a significant role. ${ }^{1-3}$ Neuroprotection attributed to $\mathrm{A}_{2 \mathrm{~A}} \mathrm{AR}$ antagonists have been associated also with their ability to reduce glutamate levels by decreasing its release $\mathrm{e}^{10-12}$ and enhancing its glial uptake. ${ }^{6,13,14}$

$\mathrm{A}_{2 \mathrm{~A}} \mathrm{AR}$ is also involved in the development of neuropathic pain and its blockade confers protection. ${ }^{15}$ Neuropathic pain is a common type of chronic pain, which occurs in several disorders and results in several factors leading to impairment in nerve function. Its pathophysiology is quite complex and involves both central and peripheral mechanisms with alterations in the ion channel expression, neurotransmitter release, and pain pathways. ${ }^{16}$ Although the molecular basis of neuropathic pain is not completely understood, oxidative stress might contribute to its development. ${ }^{17-19}$ In pain following spinal cord injury, beside dysfunction of neurons, other pathogenic events occur, including microglia activation and enhanced extracellular glutamate which, in turn, activates intracellular pathways such as ROS formation. ${ }^{20}$ Platinum-based anticancer drugs can cause peripheral neuropathy involving sensory nerves and it has been demonstrated that the treatment with this kind of drugs induces, among others, ROS generation, damage at nuclear and mitochondrial DNA, loss in antioxidant enzymes, and nerve tissue impairment. ${ }^{20}$ In accordance, systemic administration of antioxidant ${ }^{17,18}$ or ROS scavenger ${ }^{17}$ produces pain relief in different animal model of neuropathic pain. 
The role of the $A_{2 A} A R$ in pain is still controversial because several studies support both its pro- and anti-nociceptive role, depending on the receptor localization and the type of pain. ${ }^{21}$ Coherent with a pro-nociceptive role it was observed that after peripheral nerve injury, $A_{2 A} A R$ stimulation induces both activation and proliferation of microglia and astrocytes responsible of inflammation occurring in neuropathic pain, while genetic deletion of the $A_{2 A} A R$ decreases all the behavioral and histological signs of pain. ${ }^{15}$ Several studies also showed that systemic $^{22,23}$ and spinal $^{24}$ administration of the selective $\mathrm{A}_{2 \mathrm{~A}} \mathrm{AR}$ antagonist 2-(furan-2-yl)-7-phenethyl-7H-pyrazolo[4,3-e]1,2,3-triazolo[1,5-c]pyrimidin-5-amine (SCH58261) produced antinociception in several preclinical models. Moreover, potent $\mathrm{hA}_{2 \mathrm{~A}}$ inverse agonists belonging to our thiazolo[5,4- $d$ ]pyrimidine series showed an anti-nociceptive effect equal to or greater than morphine in acute pain models. ${ }^{25}$

Taking into account these premises, over the last few years we have directed a part of our research to obtaining new $\mathrm{A}_{2 \mathrm{~A}} \mathrm{AR}$ antagonists belonging to bicyclic ${ }^{25-33}$ and monocyclic ${ }^{34}$ heterocyclic classes. Among the former, the 8-amino-2-phenyl-1,2,4-triazolo[4,3-a]pyrazine-3-one series ${ }^{27,33}$ was investigated and several potent $\mathrm{hA}_{2 \mathrm{~A}} \mathrm{AR}$ antagonists were identified, some of which proved to be neuroprotective in $\mathrm{PD}^{27}$ and $\mathrm{AD}^{33}$ in vitro models. In this paper we describe new 1,2,4triazolo[4,3-a]pyrazines designed as $\mathrm{hA}_{2 \mathrm{~A}} \mathrm{AR}$ antagonists bearing an unsubstituted phenyl ring at position 2 and different moieties at position $6(\mathbf{1 - 2 1})$. The former group was chosen since it proved to be an important feature to obtain an efficient $\mathrm{hA}_{2 \mathrm{~A}}$ receptor-ligand interaction, ${ }^{27}$ while the 6substituents were mostly selected to obtain dual acting antioxidant- $\mathrm{A}_{2 \mathrm{~A}} \mathrm{AR}$ antagonists. Compounds endowed with this mixed activity have attracted our attention since they would possess a potentially increased protective effect both in neurodegenerative diseases and in neuropathic pain. The new triazolopyrazines can be subdivided into two sets, depending on the type of the 6-substituent. 


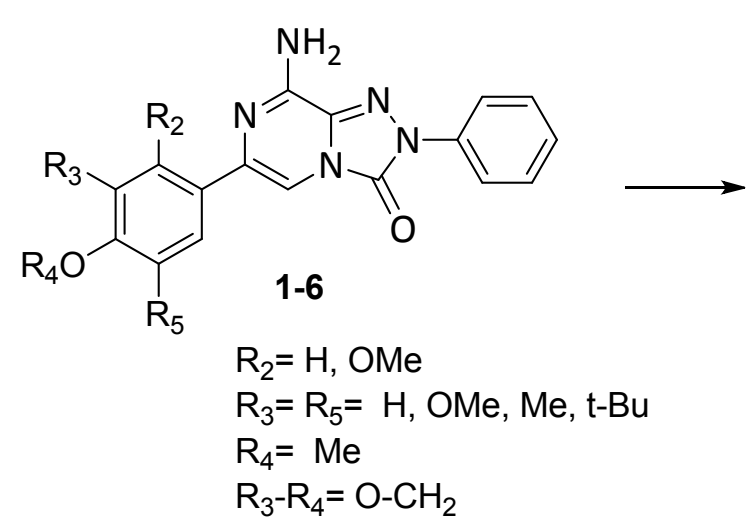

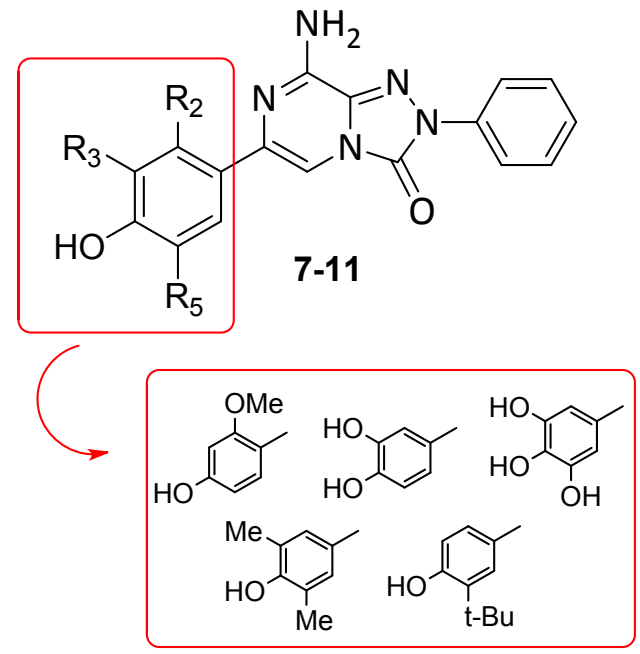

Figure 1. New 8-amino-2-phenyl-1,2,4-triazolo[4,3-a]pyrazin-3-ones 1-11.

In the first set (1-11, Figure 1), derivatives 7-11 bear phenolic and polyphenolic rings at the 6position. These kinds of substituents were chosen since they are a common feature of both natural and synthetic antioxidant agents. Among them, naturally occurring hydroxycinnamic acids, such as caffeic and ferulic acids, and resveratrol (Figure 2) were proven to exert diverse bioactivities affording neuroprotective effects. ${ }^{35-37}$ 3,5-Di-tert-butyl-4-hydroxytoluene (BHT) is a synthetic antioxidant used for food and pharmaceuticals. ${ }^{37}$ Like other hindered phenols, BHT can exert biological functions for its ability to intercept and react with free radicals through atom transfer. ${ }^{38}$<smiles>[R]Oc1ccc(/C=C/C(=O)O)cc1O</smiles>

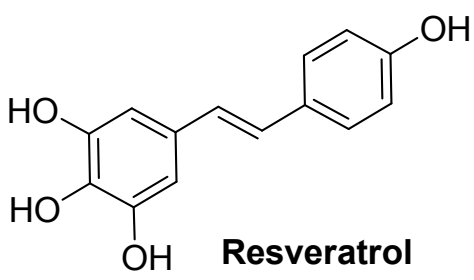<smiles>Cc1cc(C(C)(C)C)c(O)c(C(C)(C)C)c1</smiles>

Figure 2. Some natural and synthetic antioxidant agents.

Considering our triazolopyrazines 7-11, electron-donating groups were also introduced on the 6-(4hydroxyphenyl) ring, in particular at the ortho position of the hydroxy group (Me, tert-But). These 
substituents might have a role in improving radical scavenging activity, which may be mainly related to their ability to delocalize/stabilize the resulting phenoxyl radical. ${ }^{37}$

The second set of triazolopyrazines (12-21, Figure 3) was synthesized to obtain derivatives 15-17, 20, 21, in which antioxidant moieties were spaced by different linkers from the para position of the 6-phenyl ring.

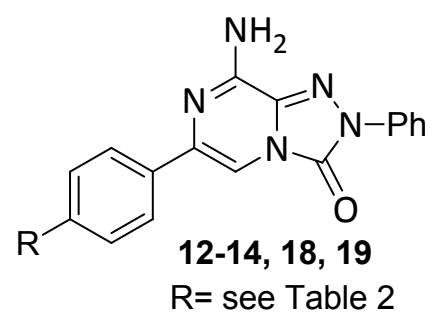

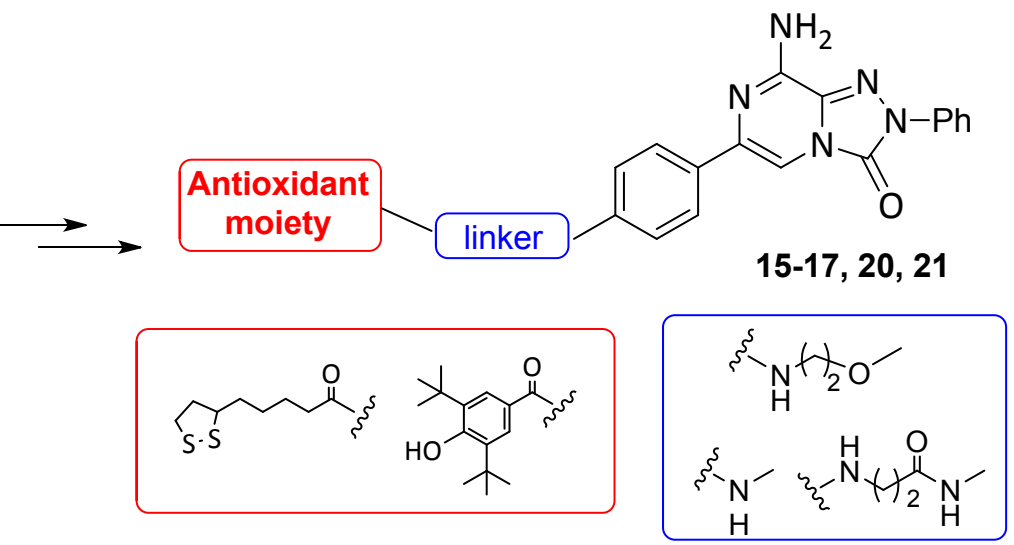

Figure 3. New 8-amino-2-phenyl-1,2,4-triazolo[4,3-a]pyrazin-3-ones 12-21.

As antioxidant pendants, we selected $\alpha$-lipoic and 3,5-di-tert-butyl-4-hydroxybenzoic acid residues. The latter was chosen for its structural similarity to BHT, the former because, besides being a naturally occurring compound present in food and used as dietary integrator, it emerged in preclinical studies as a promising agent for the treatment and/or prevention of neurodegenerative disorders. $^{39-41}$ At a molecular level, $\alpha$-lipoic acid is effective in scavenging free radicals and reducing oxidative stress. It also increases or maintains cellular glutathione levels by acting as a transcriptional inducer of genes governing glutathione synthesis. Clinical studies investigating the effect of $\alpha$-lipoic acid on diabetic neuropathy have revealed its efficacy in relieving neuropathic pain symptoms. ${ }^{42,43}$ 


\begin{abstract}
All the newly synthesized triazolopyrazines 1-21 were evaluated for their affinity at ARs. These derivatives include not only the target compounds, bearing antioxidant moieties, but also their synthetic precursors and some derivatives prepared to broaden SAR studies.
\end{abstract}

\title{
RESULTS AND DISCUSSION
}

Chemistry. The 1,2,4-triazolopyrazin-3-one derivatives 1-21 were prepared as depicted in Schemes 1-3. Compounds 1-11 (Scheme 1) were obtained starting from ethyl 5-oxo-1-phenyl-4,5-dihydro$1 H$-1,2,4-triazole-3-carboxylate $\mathbf{2 2}^{44}$ which was regioselectively $\mathrm{N}^{4}$-alkyated with the suitable $\alpha$ bromoketones 23-28. Of the latter, 23-26 were previously reported, ${ }^{45-48}$ while 27 and $\mathbf{2 8}$ were newly synthesized in the same conditions employed to obtain $\mathbf{2 3 - 2 6}$, i.e. by brominating the corresponding acetophenone derivatives 29 and $\mathbf{3 0}$. Compound 29 was commercially available while $\mathbf{3 0}$ was synthesized by methylation of (4-hydroxy-3,5-di-tert-butyl)phenylethanone. ${ }^{49}$ The $\mathrm{N}_{4}$-alkyltriazole derivatives 31-36 were cyclized with ammonium acetate, by heating in a sealed tube, to give the 1,2,4-triazolo[4,3-a]pyrazine-3,8-dione derivatives 37-42 which were chlorinated with phosphorus oxychloride, under microwave irradiation, to give the related 8-chloro derivatives 43-48. Their treatment with a saturated ethanolic solution of ammonia gave the desired 8-amino-1,2,4triazolo[4,3-a]pyrazine-3-one derivatives 1-6. Reaction of the 6-(2,4-dimethoxy)phenyl derivative $\mathbf{1}$ with $\mathrm{BBr}_{3} 1 \mathrm{M}$ dichloromethane solution produced demethylation of the methoxy group at position 4, yielding to the 4-hydroxy-2-methoxyphenyl derivative 7. Its structure was established by NOESY experiment, indicating the spatial proximity between the methoxy group and the sole aromatic proton at position 3 . 


\section{Scheme $1^{a}$}<smiles>[R]c1cc(C(C)=O)cc([R])c1OC</smiles>

$29 \mathrm{R}=\mathrm{CH}_{3}$

$30 \mathrm{R}=\mathrm{t}-\mathrm{But}$<smiles></smiles>

22

b<smiles>[R6]C(=O)CBr</smiles><smiles>[R6]c1cn2c(=O)n(-c3ccccc3)nc2c(Cl)n1</smiles>

$\mathrm{g} \lcm{1-6}$<smiles>[R6]C(=O)Cn1c(C(=O)OCC)nn(-c2ccccc2)c1=O</smiles>

$\mathrm{d} \downarrow$<smiles>[R6]c1cn2c(=O)n(-c3ccccc3)nc2c(=O)[nH]1</smiles>

37-42

\begin{tabular}{|c|c|c|c|}
\hline & $\mathrm{R}_{6}$ & & $\mathrm{R}_{6}$ \\
\hline $1,23,31,37,43$ & $\mathrm{C}_{6} \mathrm{H}_{4}-2,4-\mathrm{diOCH}_{3}$ & 7 & $\mathrm{C}_{6} \mathrm{H}_{4}-2-\mathrm{OCH}_{3}-4-\mathrm{OH}$ \\
\hline $2,24,32,38,44$ & $\mathrm{C}_{6} \mathrm{H}_{4}-3,4-\mathrm{diOCH}_{3}$ & 8 & $\mathrm{C}_{6} \mathrm{H}_{4}-3,4-\mathrm{diOH}$ \\
\hline $3,25,33,39,45$ & $\mathrm{C}_{6} \mathrm{H}_{4}-3,4-\mathrm{OCH}_{2} \mathrm{O}$ & 9 & $\mathrm{C}_{6} \mathrm{H}_{4}-3,4,5$-triOH \\
\hline $4,26,34,40,46$ & $\mathrm{C}_{6} \mathrm{H}_{4}-3,4,5-$ triOCH$_{3}$ & 10 & $\mathrm{C}_{6} \mathrm{H}_{4}-4-\mathrm{OH}-3,5-\mathrm{diCH}_{3}$ \\
\hline $5,27,35,41,47$ & $\mathrm{C}_{6} \mathrm{H}_{4}-4-\mathrm{OCH}_{3}-3,5-\mathrm{diCH}_{3}$ & 11 & $\mathrm{C}_{6} \mathrm{H}_{4}-4-\mathrm{OH}-\mathrm{tBu}$ \\
\hline $6,28,36,42,48$ & $\mathrm{C}_{6} \mathrm{H}_{4}-4-\mathrm{OCH}_{3}-3,5-$ di-tBu & & \\
\hline
\end{tabular}

${ }^{a}$ Reagents and conditions: (a) $\mathrm{K}_{2} \mathrm{CO}_{3}, \mathrm{DMF} / \mathrm{CH}_{3} \mathrm{CN}, \quad \mathrm{rt}$; (b) $\mathrm{Br}_{2}, \mathrm{CHCl}_{3} / \mathrm{Et}_{2} \mathrm{O}, 0{ }^{\circ} \mathrm{C}$ rt; (c) $\mathrm{CH}_{3} \mathrm{I}, \mathrm{K}_{2} \mathrm{CO}_{3}$, 2-butanone, reflux; (d) $\mathrm{NH}_{4} \mathrm{OAc}, 140{ }^{\circ} \mathrm{C}$ sealed tube; (e) $\mathrm{POCl}_{3}$, mw $170{ }^{\circ} \mathrm{C}$; (f) $\mathrm{NH}_{3}$, absolute EtOH; (g) $\mathrm{BBr}_{3}$, anhydrous $\mathrm{CH}_{2} \mathrm{Cl}_{2}, 0{ }^{\circ} \mathrm{C}$ - rt.

Demethylation of the (methoxyphenyl) derivatives 2 and 4, 5 with $\mathrm{BBr}_{3}(1 \mathrm{M}$ dichloromethane solution) gave the corresponding hydroxyphenyl-substituted compounds 8-10. These conditions did 
not work to demethylate the 6-(3,5-di-tert-butyl-4-methoxy)phenyl derivative 6, probably due to the steric bulk of the two tert-butyl groups. Reaction was successful in more drastic conditions, i.e. with $48 \%$ aqueous $\mathrm{HBr}$ at reflux which, however, caused the removal of a tert-butyl substituent. Thus, the 3-tert-butyl-4-hydroxy derivative 11 was obtained, instead of the desired 4-hydroxy-3,5-di-tertbutyl derivative. Scheme 2 depicts the synthesis of the triazolopyrazines 12-16, of which 15 and 16 were the target compounds linking antioxidant moieties.

\section{Scheme $2^{a}$}<smiles>[R]COc1ccc(-c2cn3c(=O)n(-c4ccccc4)nc3c(N)n2)cc1</smiles><smiles>[R]NCCOc1ccc(-c2cn3c(=O)n(-c4ccc([R5])cc4)nc3c(N)n2)cc1</smiles>

${ }^{a}$ Reagents and conditions: a) $\mathrm{NC}-\mathrm{CH}_{2}-\mathrm{Cl}$ or $\mathrm{NH}_{2}-\mathrm{CO}-\mathrm{CH}_{2}-\mathrm{Cl}, \mathrm{K}_{2} \mathrm{CO}_{3}$, anhydrous acetone, reflux; b) $\mathrm{LiAlH}_{4}$, anhydrous THF, $0{ }^{\circ} \mathrm{C}$; c) (R, S) lipoic acid or 3,5-di-tert-butyl-4-hydroxybenzoic acid, 1(3-(dimethylamino)-propyl))-3-ethylcarbodiimide hydrochloride, $\mathrm{NEt}_{3}, 1$-hydroxybenzotriazole, anhydrous DMF, rt.

The starting material was the previously reported 6-(4-hydroxy)phenyl-triazolopyrazine $\mathbf{4 9}^{27}$ which was O-alkylated with the suitable alkyl halides to give the corresponding 6-(4-O-alkylated) 
compounds 12 and $\mathbf{1 3}$. The cyano derivative 12 was reduced at $\mathrm{rt}$ with $\mathrm{LiAlH}_{4}$ to afford the 6-(4-(2aminoethoxy)phenyl compound $\mathbf{1 4}$ which was reacted with (R,S) lipoic acid and 3,5-ditertbutyl-4hydroxybenzoic acid, in anhydrous DMF and in presence of 1-hydroxybenzotriazole, 1(dimethylamino)-propyl))-3-ethylcarbodiimide hydrochloride and triethylamine, to yield the desired derivatives $\mathbf{1 5}$ and $\mathbf{1 6 .}$

The synthesis of the triazolopyrazines $\mathbf{1 7 - 2 1}$ is shown in Scheme 3. The 6-(4-lipoylaminophenyl) derivative 17 was obtained by reacting the previously reported 6-(4-aminophenyl) derivative $\mathbf{5 0}^{33}$ with (R,S) lipoic acid, in the same conditions described above to prepare $\mathbf{1 5}$ from 14.

\section{Scheme $3^{a}$}<smiles>CC(C)CCCCCCCC(=O)Nc1ccc(-c2cn3c(=O)n(-c4ccccc4)nc3c(N)n2)cc1</smiles><smiles>[R]NCCC(=O)Nc1ccc(-c2cn3c(=O)n(-c4ccccc4)nc3c(N)n2)cc1</smiles>

18

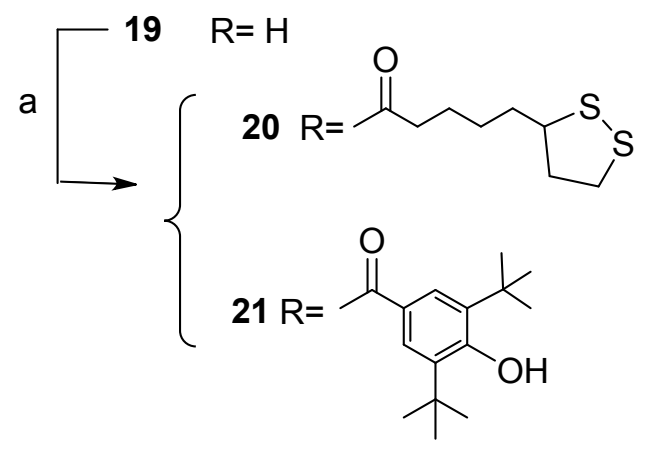

${ }^{a}$ Reagents and conditions: a) (R, S) lipoic acid or 3,5-di-tert-butyl-4-hydroxybenzoic acid, 1-(3(dimethylamino)-propyl))-3-ethylcarbodiimide hydrochloride, $\mathrm{NEt}_{3}$, 1-hydroxybenzotriazole, 
anhydrous DMF, rt; b) Cl- $\left(\mathrm{CH}_{2}\right)_{2}-\mathrm{COOH}$, 1-(3-(dimethylamino)-propyl))-3-ethylcarbodiimide hydrochloride, $\mathrm{NEt}_{3}$, anhydrous DMF, rt; c) $\mathrm{NH}_{3}$ gas/ absolute EtOH, sealed tube, $130{ }^{\circ} \mathrm{C}$.

When the same experimental conditions were employed to react compound 50 with 3chloropropionic acid, the 6-(4-acrylamidophenyl) derivative 18 was obtained which was allowed to react with a saturated solution of ammonia in absolute ethanol to afford the 6-(4-(3aminopropanamido)phenyl-derivative 19. This intermediate was transformed into derivatives 20 and 21 by acylation with $(\mathrm{R}, \mathrm{S})$ lipoic acid and 3,5-ditertbutyl-4-hydroxybenzoic acid, respectively, in the same conditions described above to obtain $\mathbf{1 5}$ from 14.

\section{Binding and cAMP assays}

All the newly synthesized triazolopyrazines 1-21 were evaluated for their affinity at $\mathrm{hA}_{1}, \mathrm{hA}_{2 \mathrm{~A}}$ and $\mathrm{hA}_{3} \mathrm{ARs}$, stably transfected in Chinese hamster ovary $(\mathrm{CHO})$ cells, and were tested at the $\mathrm{hA}_{2 \mathrm{~B}} \mathrm{AR}$ subtype by determining their inhibitory effects on NECA-stimulated cAMP levels in $\mathrm{hA}_{2 \mathrm{~B}} \mathrm{CHO}$ cells (Tables 1 and 2). Derivatives 11, 12, 15, 20 and 21, showing high $\mathrm{hA}_{2 \mathrm{~A}} \mathrm{AR}$ affinity and selectivity, were selected to assess their antagonistic profile. Hence, their ability to inhibit or stimulate the $\mathrm{hA}_{2 \mathrm{~A}} \mathrm{AR}$ was determined by evaluating their effect on cAMP production in $\mathrm{CHO}$ cells, stably expressing $\mathrm{hA}_{2 \mathrm{~A}}$ ARs (Table 3).

\section{Structure-Affinity Relationship Studies}

The results reported in Tables 1 and 2 displayed that several of the targeted triazolopyrazines featuring potential antioxidant moieties $\left(7-8,10,11\right.$ and 15, 17, 20, 21) showed nanomolar hA $\mathrm{A}_{2 \mathrm{~A}}$ AR affinity and different degrees of selectivity. Within the first set of compounds (Table 1), the 6(4-hydroxy-3-terbutyl)-phenyl derivative 11 was the most selective for the $\mathrm{hA}_{2 \mathrm{~A}} \mathrm{AR}\left(\mathrm{K}_{\mathrm{i}}=8.5 \mathrm{nM}\right)$. 
The other phenolic derivatives $(\mathbf{7}, \mathbf{8}$ and $\mathbf{1 0})$ showed nanomolar affinity at the $\mathrm{hA}_{2 \mathrm{~A}} \mathrm{AR}$, compound 10 being the most active $\left(\mathrm{K}_{\mathrm{i}}=2.5 \mathrm{nM}\right)$, but scarce selectivity since they were able to bind the $\mathrm{h} \mathrm{A}_{1}$ subtype with significant affinity $\left(\mathrm{K}_{\mathrm{i}}=21.3-42.6 \mathrm{nM}\right)$.

Table 1. Biological activity of compounds 1-11 at hARs. ${ }^{\mathrm{a}}$

\begin{tabular}{|c|c|c|c|c|c|}
\hline & & \multicolumn{2}{|c|}{ Binding experiments } & & $\begin{array}{c}\text { cAMP assays } \\
\qquad \mathrm{IC}_{50}(\mathrm{nM})\end{array}$ \\
\hline & $\mathrm{R}_{6}$ & $\mathrm{hA}_{1}^{\mathrm{b}}$ & $\mathrm{hA}_{2 \mathrm{~A}}{ }^{\mathrm{c}}$ & $\mathrm{hA}_{3}{ }^{\mathrm{d}}$ & $\mathrm{hA}_{2 \mathrm{~B}}^{\mathrm{e}}$ \\
\hline 1 & & $28 \pm 0.3$ & $2.4 \pm 0.5$ & $118 \pm 6.6$ & $>30000$ \\
\hline 2 & & $59 \pm 12.7$ & $5.7 \pm 0.8$ & $80.1 \pm 15.8$ & $>30000$ \\
\hline 3 & & $13 \pm 2.5$ & $7.4 \pm 0.9$ & $38 \pm 6.7$ & $>30000$ \\
\hline 4 & & $55 \pm 16$ & $3.5 \pm 0.8$ & $214 \pm 4.4$ & $>30000$ \\
\hline 5 & & $4.5 \pm 1.4$ & $0.17 \pm 0.004$ & $8.6 \pm 1.7$ & $>30000$ \\
\hline 6 & & $108.5 \pm 17$ & $141.6 \pm 34$ & $>30000$ & $>30000$ \\
\hline 7 & & $29.7 \pm 1.6$ & $16.8 \pm 0.9$ & $11130 \pm 975$ & $>30000$ \\
\hline
\end{tabular}




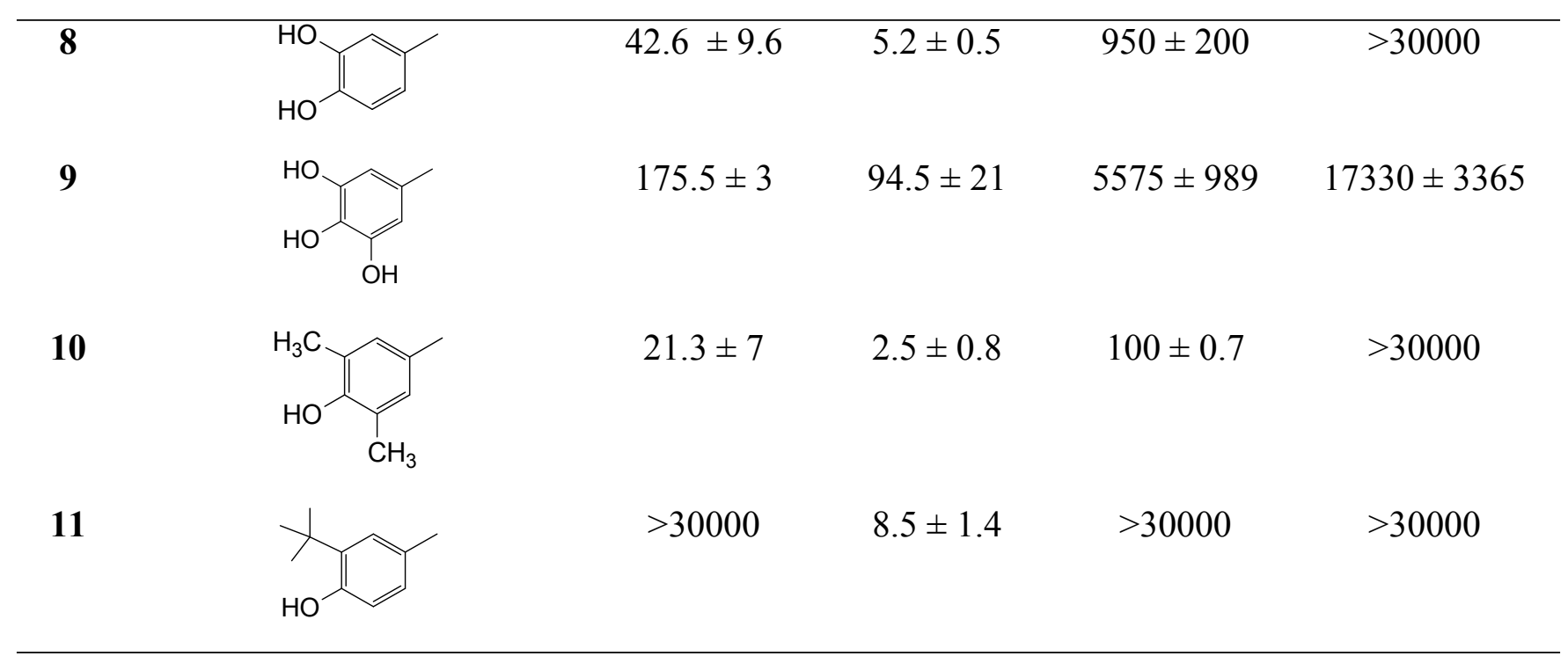

${ }^{\text {aData }}(\mathrm{n}=3-5)$ are expressed as means \pm standard errors. ${ }^{b}$ Displacement of specific $\left[{ }^{3} \mathrm{H}\right]-\mathrm{CCPA}$ binding at $h \mathrm{~A}_{1} \mathrm{AR}$ expressed in $\mathrm{CHO}$ cells. ${ }^{\mathrm{c}}$ Displacement of specific $\left[{ }^{3} \mathrm{H}\right]-\mathrm{NECA}$ binding at $\mathrm{h} \mathrm{A}_{2 \mathrm{~A}} \mathrm{AR}$ expressed in $\mathrm{CHO}$ cells. ${ }^{\mathrm{d}}$ Displacement of specific $\left[{ }^{3} \mathrm{H}\right]$-HEMADO binding at $\mathrm{hA} \mathrm{A}_{3} \mathrm{AR}$ expressed in $\mathrm{CHO}$ cells. ${ }^{\mathrm{e}} \mathrm{IC}_{50}$ values of the inhibition of NECA-stimulated adenylyl cyclase activity in CHO cells expressing $\mathrm{hA}_{2 \mathrm{~B}} \mathrm{AR}$.

Derivatives 1-6, including the methoxy synthetic intermediates and the 6-(3,4methylenedioxyphenyl) derivative $\mathbf{3}$, on the whole, showed high affinities for the $\mathrm{hA}_{2 \mathrm{~A}} \mathrm{AR}$, spanning one-digit nanomolar values, and also for the $\mathrm{hA}_{1}$ subtype. The most active compound at the $\mathrm{hA}_{2 \mathrm{~A}}$ AR was derivative $5\left(\mathrm{~K}_{\mathrm{i}}=0.17 \mathrm{nM}\right)$, featuring the 6-(3,5-dimethyl-4-methoxyphenyl) substitution, while its 6-(3,5-di-tert-butyl-4-methoxyphenyl) analogue 6 showed significantly lower $\mathrm{hA}_{2 \mathrm{~A}}$ AR binding activity $\left(\mathrm{K}_{\mathrm{i}}=141.6 \mathrm{nM}\right)$, probably due to the steric bulk of the two tert-butyl groups. Compounds $\mathbf{5}$ and $\mathbf{3}$ also possess significant affinity for the $\mathrm{hA}_{3}$ subtype.

In the second set of triazolopyrazines (12-21), $\alpha$-lipoic acid and 4-hydroxy-3,5-ditertbutylbenzoic acid were selected as antioxidant portions and linked by different chains at the para position of the 6-phenyl ring. The choice of this position was based on the results of previous molecular docking 
studies of this class of compounds at the $\mathrm{hA}_{2 \mathrm{~A}} \mathrm{AR}$, highlighting that the presence of hindering substituents on the 6-phenyl ring favored a binding pose with this moiety pointing towards the extracellular side of the receptor. Hence, we envisaged that long substituents at the para position could be well tolerated because they could point away from the binding pocket. The selected chains were linked through an ethereal (compounds 15, 16) or an amide function (compounds 17, 20 and 21).

Table 2. Biological activity of derivatives 12-21 and the reference compounds 49 and 50, at hARs. ${ }^{\mathrm{a}}$

12 (12 13


17<smiles>NC(=O)CCCCC1CCSS1</smiles>

18<smiles>C=CC(N)=O</smiles>

19<smiles>NCCC(N)=O</smiles>

20<smiles>NC(=O)CNCCCCCC1CCSS1</smiles>

21<smiles>CC(C)(C)c1cc(C(=O)NCCC(N)=O)cc(C(C)(C)C)c1O</smiles>

$$
8.4 \pm 0.4
$$

$262.7 \pm 1.9$

$479.2 \pm 89$

$1359 \pm 284$

$>30000$

$45 \pm 10$

$33.5 \pm 6.7$

$$
5 \pm 0.6
$$

$1.8 \pm 0.09$

$0.59 \pm 0.2$

$36.4 \pm 8.2$

$54.5 \pm 7.1$

$45 \pm 12$

$22.9 \pm 0.2$
$>30000$

$>30000$

$>30000$

$>30000$

$509 \pm 90 \quad 9658 \pm 1431$

$>30000$

$>30000$

$49^{f}$

$\mathrm{NH}_{2}$

${ }^{a}$ Data $(n=3-5)$ are expressed as means \pm standard errors. ${ }^{b}$ Displacement of specific $\left[{ }^{3} \mathrm{H}\right]-\mathrm{CCPA}$ binding at $\mathrm{hA} \mathrm{A}_{1} \mathrm{AR}$ expressed in $\mathrm{CHO}$ cells. ${ }^{\mathrm{c}}$ Displacement of specific $\left[{ }^{3} \mathrm{H}\right]-\mathrm{NECA}$ binding at $\mathrm{hA} \mathrm{A}_{2 \mathrm{~A}} \mathrm{AR}$ expressed in $\mathrm{CHO}$ cells. ${ }^{\mathrm{d}}$ Displacement of specific $\left[{ }^{3} \mathrm{H}\right]$-HEMADO binding at $\mathrm{hA_{3 }}$ AR expressed in $\mathrm{CHO}$ cells. ${ }^{\mathrm{e}} \mathrm{IC}_{50}$ values of the inhibition of NECA-stimulated adenylyl cyclase activity in $\mathrm{CHO}$ cells expressing

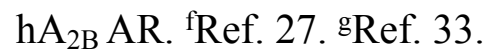

The binding data (Table 2) proved us right. On the whole, all the substituents appended on the 4hydroxy- and 4-amino group of derivatives 49 and 50, respectively, increased affinity and /or selectivity for the $\mathrm{hA}_{2 \mathrm{~A}} \mathrm{AR}$ (compare derivatives 12-16 to 49 and compounds 17-21 to 50), with the only exception being compound 16, which showed a dropped $\mathrm{hA}_{2 \mathrm{~A}} \mathrm{AR}$ binding activity.

The lipoyl derivatives $\mathbf{1 5}, \mathbf{1 7}$ and $\mathbf{2 0}$ resulted in high affinity $\mathrm{hA}_{2 \mathrm{~A}} \mathrm{AR}$ ligands $\left(\mathrm{K}_{\mathrm{i}}=2.4-36.4 \mathrm{nM}\right)$ with different degrees of selectivity versus the $\mathrm{hA}_{1} \mathrm{AR}$, depending on the nature of the linker. 
Compound 17, bearing the lipoyl residue directly attached on the para-amino group, showed a high affinity not only for the $\mathrm{hA}_{2 \mathrm{~A}}$ receptor but also for the $\mathrm{hA}$ AR subtype. Very interesting results were obtained when the lipoyl moiety was spaced from the para-position through the flexible oxyethylamino chain (-O- $\left.\left(\mathrm{CH}_{2}\right)_{2}-\mathrm{NH}-\right)$. In fact, the resulting compound $\mathbf{1 5}$ possessed a very high affinity for the targeted $\mathrm{hA}_{2 \mathrm{~A}}$ receptor $\left(\mathrm{K}_{\mathrm{i}}=2.4 \mathrm{nM}\right)$ and also high selectivity, being significantly less active at the $\mathrm{hA}_{1} \mathrm{AR}\left(\mathrm{K}_{\mathrm{i}}=378.6 \mathrm{nM}\right)$. When the oxyethylamino spacer was replaced by the longer and more rigid carboxyamidoethylamino spacer (-NH-CO- $\left.\left(\mathrm{CH}_{2}\right)_{2}-\mathrm{NH}-\right)$, a selective ligand for the $\mathrm{hA}_{2 \mathrm{~A}} \mathrm{AR}$ was still obtained (compound 20) but its affinity and selectivity were lower, with respect to those of $\mathbf{1 5}$. The same two spacers were employed to link the (4-hydroxy-3,5-di-tertbutyl)benzoyl pendant to the 6-phenyl ring (derivative 16 and 21) but in this case an opposite effect was obtained since the best results, both in terms of $A_{2 A} A R$ affinity and selectivity, were obtained with the carboxyamidoethylamino spacer. In fact, compound 21 showed good affinity for the $\mathrm{hA}_{2 \mathrm{~A}}$ AR $\left(\mathrm{K}_{\mathrm{i}}=54.5 \mathrm{nM}\right)$ and high selectivity, while it analogue 16 was almost inactive at all ARs. The significant difference between $\mathrm{hA}_{2 \mathrm{~A}}$ affinities of the two compounds obviously depends on the different spacer. The bit longer carboxyamidoethylamino spacer seems to direct the terminal bulky aryl ring in a more favorable pose in the receptor binding site (see modeling analysis). Also derivatives 12-14 and 18, 19, which were not our primary target compounds, resulted in interesting ligands, showing nanomolar affinity and good to high selectivity for the $\mathrm{hA}_{2 \mathrm{~A}} \mathrm{AR}$. In particular, derivative 19, bearing the carboxyamido-ethylamine substituent at the para position of the 6-phenyl ring, was the most active $\left(\mathrm{K}_{\mathrm{i}}=0.59 \mathrm{nM}\right)$. Derivatives 12 and 18, featuring at the para-position a cyanomethoxy $\left(\mathrm{K}_{\mathrm{i}}=8.2 \mathrm{nM}\right)$ and an acrilamido group $\left(\mathrm{K}_{\mathrm{i}}=1.8 \mathrm{nM}\right)$, respectively, displayed high $\mathrm{hA}_{2 \mathrm{~A}} \mathrm{AR}$ affinities and selectivity. Reduction of the cyano residue of compound $\mathbf{1 2}$ afforded the amino derivative $\mathbf{1 4}$ which maintained the ability to target the $\mathrm{hA}_{2 \mathrm{~A}} \mathrm{AR}$ with nanomolar affinity $\left(\mathrm{K}_{\mathrm{i}}=14.9 \mathrm{nM}\right)$ but lower selectivity. Transformation of the cyano in amide group (compound 13) also retained affinity but reduced selectivity for the target $\mathrm{hA_{2A }}$ receptor. 
Finally, compounds 11, 12, 15, 20 and 21, showing high $\mathrm{hA}_{2 \mathrm{~A}} \mathrm{AR}$ affinity and selectivity, were selected to be further pharmacologically profiled in in vitro studies. Previously, we ascertained their antagonistic profile by evaluating their effect on cAMP production in $\mathrm{CHO}$ cells, stably expressing $\mathrm{hA}_{2 \mathrm{~A}}$ ARs (Table 3). The compounds proved to be able to counteract NECA-stimulated cAMP production, thus behaving as $\mathrm{hA}_{2 \mathrm{~A}} \mathrm{AR}$ antagonists.

Table 3. Potencies of the selected triazolopyrazines 11, 12, 15, 20 and 21 at $h A_{2 \mathrm{~A}} \mathrm{AR}$.

\begin{tabular}{lc}
\hline & $\mathrm{hA}_{2 \mathrm{~A}} \mathrm{AR}\left(\mathrm{IC}_{50} \mathrm{nM}\right)^{\mathrm{a}}$ \\
\hline $\mathbf{1 1}$ & $179 \pm 53$ \\
$\mathbf{1 2}$ & $157 \pm 43$ \\
$\mathbf{1 5}$ & $116 \pm 31$ \\
$\mathbf{2 0}$ & $296 \pm 66$ \\
$\mathbf{2 1}$ & $263 \pm 58$ \\
\hline
\end{tabular}

${ }^{\mathrm{a}} \mathrm{IC}_{50}$ values of the inhibition of NECA-stimulated adenylyl cyclase activity in CHO cells expressing $\mathrm{hA}_{2 \mathrm{~A}} \mathrm{AR}$. Data are expressed as means \pm standard errors.

Molecular modeling studies. The binding mode of the synthesized compounds at the $\mathrm{hA}_{2 \mathrm{~A}} \mathrm{AR}$ cavity was simulated with docking analysis by using the MOE (Molecular Operating Environment 2014.09) software and the CCDC Gold docking tool. ${ }^{50,51}$ The MOE software analysis was carried out by selecting the induced fit docking and optimization protocol (schematically, a preliminary docking analysis providing a set of ligand conformations then energy minimized with the side chains of the receptor residues in proximity). For the docking tasks, a crystal structure of the $\mathrm{hA}_{2 \mathrm{~A}}$ AR in complex with the antagonist/inverse agonist ZM241385 was employed (http://www.rcsb.org; pdb code: $5 \mathrm{NM} 4 ; 1.7-\AA$ resolution $^{52}$ ). For a subset of compounds, the binding modes at the $\mathrm{hA}_{1} \mathrm{AR}$ crystal structure (pdb code: $5 \mathrm{~N} 2 \mathrm{~S} ; 3.3-\AA$ resolution $^{53}$ ) were also simulated with the same tools and protocols. 
The docking conformations generally obtained for the new derivatives at the $\mathrm{hA}_{2 \mathrm{~A}} \mathrm{AR}$ are similar to those observed for our previously reported triazolopyrazines and is shown in Figure 4A. ${ }^{27}$ In this binding mode, the bicyclic core is positioned between the side chains of Phe168 (EL2) and Leu2496.51 and engages non-polar interactions with these residues. The exocyclic amine group makes H-bond contacts with Asn253.55 and Glu169 (EL2), while the 2-phenyl substituent is located in the depth of the cavity. The $\mathrm{R}_{6}$ group is positioned at the entrance of the binding site and oriented toward the extracellular environment. Such compound orientation and interaction resemble the binding mode of the co-crystallized 4-(2-[7-amino-2-(2-furyl[1,2,4]-triazolo[2,3a][1,3,5]triazin-5ylamino]ethyl)phenol (ZM241385) in the employed crystal structure ${ }^{52}$ but also in other previously reported $\mathrm{hA} \mathrm{AA}_{\mathrm{A}} \mathrm{AR} \mathrm{X}$-ray structures. ${ }^{54,55}$

The presence of substituents on the 6-phenyl ring modulates the interaction with the receptor residues at the entrance of the cavity and leads to various degrees of affinity for the $\mathrm{hA} \mathrm{A}_{2 \mathrm{~A}} \mathrm{AR}$ (see Tables 1 and 2). For previously reported analogues, ${ }^{27}$ it was observed that a non-polar parasubstituent on this ring was more efficient to improve the $\mathrm{hA}_{2 \mathrm{~A}} \mathrm{AR}$ affinity than a polar one. Considering the meta-substituents of the 6-phenyl ring, the affinity data showed that the $\mathrm{hA}_{2 \mathrm{~A}} \mathrm{AR}$ affinity was not significantly influenced by the chemical-physical profile of the substituent. Compounds of this new set of triazolopyrazines, differing in polarity of para- or meta-substituent, present various $\mathrm{hA}_{2 \mathrm{~A}} \mathrm{AR}$ affinity. Considering derivatives bearing a small 4-substituent on the 6phenyl moiety, again a non-polar para-substituent on this ring appears more efficient to improve the $\mathrm{hA}_{2 \mathrm{~A}} \mathrm{AR}$ affinity than a polar one. As an example, compounds $\mathbf{5}$, the most active of the herein reported derivatives, featuring a 4-methoxy and 3,5-di-methyl groups on the 6-phenyl ring, is endowed with 15-fold higher affinity at the $\mathrm{hA}_{2 \mathrm{~A}} \mathrm{AR}$ than 10, which bears a 4-hydroxy and 3,5-dimethyl groups. 


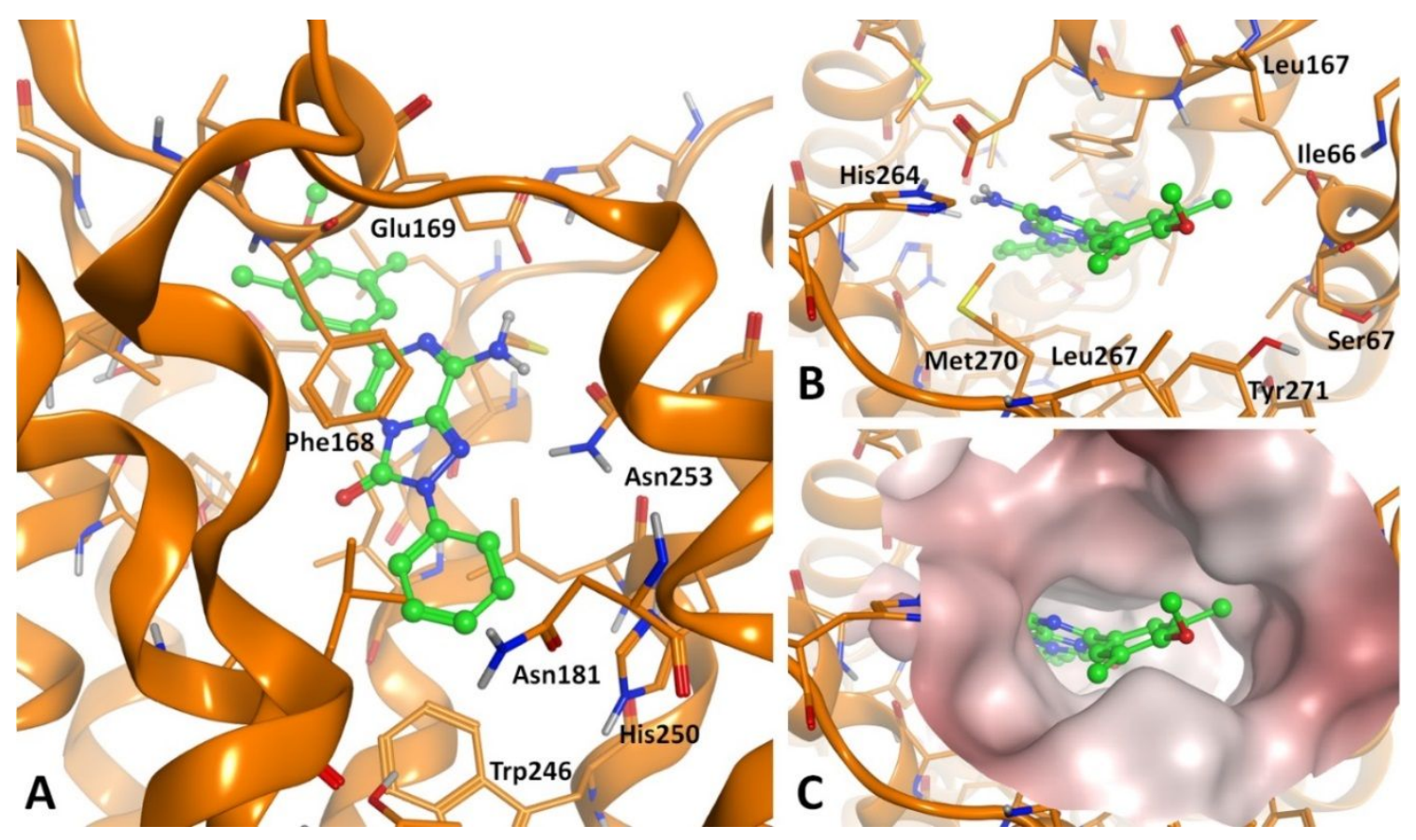

Figure 4. (A) General binding mode of the synthesized compounds at the hA $\mathrm{A}_{2 \mathrm{~A}} \mathrm{AR}$ (pdb: 5NM4) binding cavity, with indication of some key receptor residues; compound $\mathbf{5}$ is showed. (B) Top-view of the $\mathrm{hA}_{2 \mathrm{~A}} \mathrm{AR}$ residues at the entrance of the binding cavity and potentially giving interaction with substituents on the 6-phenyl ring. (C) Molecular surface representation of the entrance of the $\mathrm{hA}_{2 \mathrm{~A}}$ AR binding cavity; dark-to-light color indicates hydrophilic-to-hydrophobic scale.

The substituents inserted on the 6-phenyl ring are located in proximity of Ile66 $6^{2.64}$, Ser67 $7^{2.65}$, Leu167 (EL2), Leu267 (EL3), Met2707.35 and Tyr2717.36 (Figure 4B-C). Considering the volume, Figure $4 \mathrm{C}$ shows a molecular surface representation of the entrance of the $\mathrm{hA} \mathrm{A}_{2 \mathrm{~A}} \mathrm{AR}$ binding cavity. From this figure it can be seen that small substituents are allowed in the ortho- and meta-position of the $\mathrm{R}_{6}$ group, but the space is too limited to allow the insertion of two or more bulky moieties at the same positions. In fact, compound 6, bearing two tert-butyl groups at the meta-position of the 6phenyl ring, has a significantly reduced $\mathrm{hA}_{2 \mathrm{~A}} \mathrm{AR}$ affinity compared to the other analogues (Table 1). The non-polar profile of the above cited amino acids surrounding the $\mathrm{R}_{6}$ group allows a 
favorable interaction with non-polar substituents rather than polar ones. Combinations of para- and meta-substituents or para- and ortho-substituents lead to slight modulation of $\mathrm{hA}_{2 \mathrm{~A}} \mathrm{AR}$ affinity.

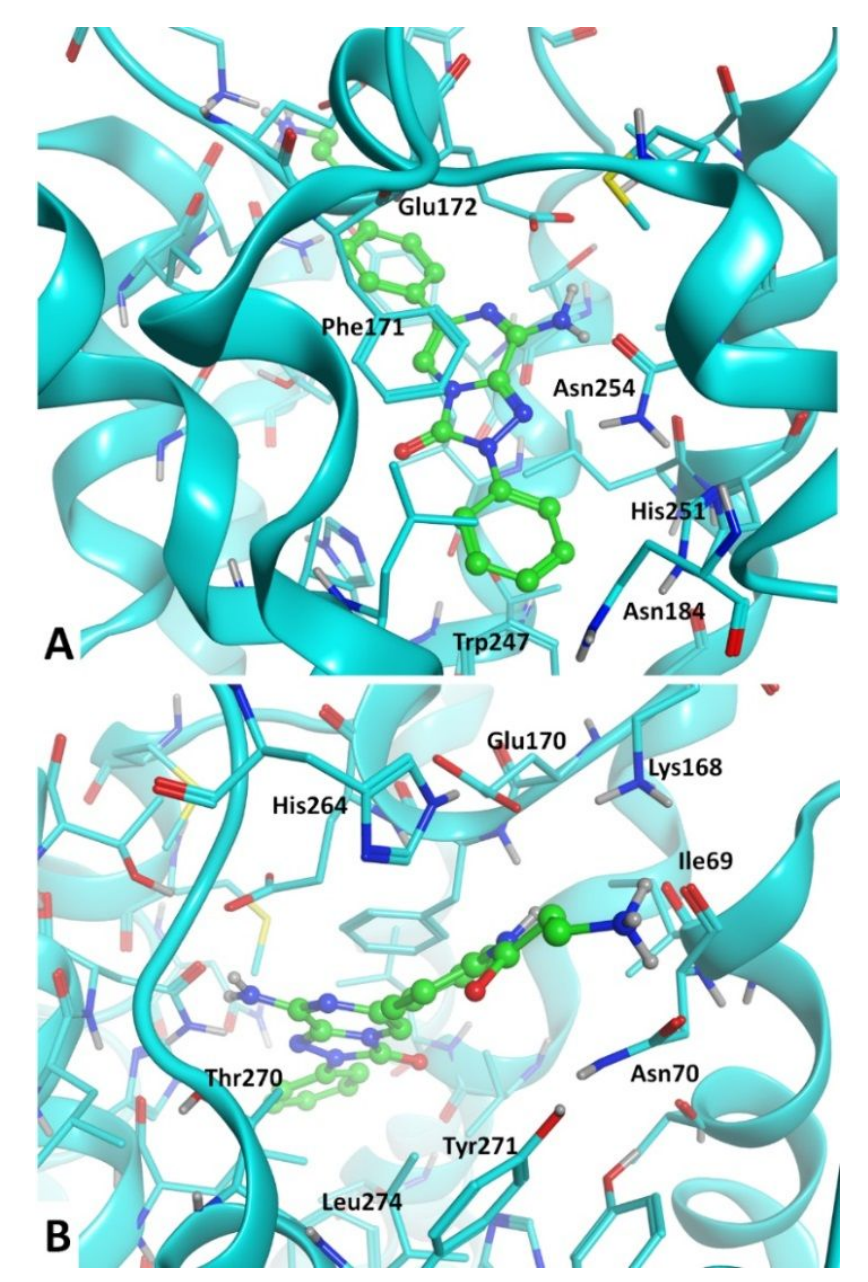

Figure 5. (A) General binding mode of the synthesized compounds at the $\mathrm{hA}_{1} \mathrm{AR}$ (pdb: 5N2S) binding cavity, with indication of some key receptor residues; compound $\mathbf{1 9}$ is showed. (B) Topview of the $\mathrm{hA}_{1} \mathrm{AR}$ residues at the entrance of the binding cavity and potentially giving interaction with substituents on the $\mathrm{R}_{6}$ aryl ring.

Docking results obtained at the $\mathrm{hA}_{1} \mathrm{AR}$ crystal structure are highly similar to the ones obtained at the $\mathrm{hA}_{2 \mathrm{~A}} \mathrm{AR}$ (Figure 5). Considering compounds bearing small substituents at the meta- and paraposition of the 6-phenyl group, docking conformations suggest analogue considerations as above for the impact on the $\mathrm{hA}_{1} \mathrm{AR}$ affinity given by these substituents. This is in agreement with biological evaluation results of compounds 1-5,7-10, which show similar trends of binding affinity 
values at $h A_{1} A R$ and $h A_{2 A} A R$. As for the $\mathrm{hA}_{2 \mathrm{~A}} \mathrm{AR}$, compound $\mathbf{5}$ is the most active of the whole set of derivatives at the $\mathrm{hA}_{1} \mathrm{AR}$, with 4-fold higher affinity than 10, its para-hydroxy substituted analogue. Even in this case, compounds bearing tert-butyl groups are endowed with lower affinity. Still considering compounds bearing small substituents at the meta- and para-position of the $\mathrm{R}_{6}$ group, affinities at the $\mathrm{hA}_{2 \mathrm{~A}} \mathrm{AR}$ are generally higher than those observed at the $\mathrm{hA} A \mathrm{AR}$. The set of $\mathrm{hA}_{2 \mathrm{~A}} \mathrm{AR}$ residues in proximity with the para-substituent is globally more hydrophobic than the $\mathrm{hA}$ AR one, due to the presence of Leu167 (EL2), Leu267 (EL3), Met2707.35 in the hA $2 \mathrm{~A}$ AR instead of the Glu170 (EL2), Ser267 (EL3) and Thr2717.35 residues in the respective positions of the hA 1 AR. This factor could play a key role in providing a slight $h \mathrm{~A}_{2 \mathrm{~A}} \mathrm{AR}$ selectivity (versus the $\mathrm{hA_{1 }} A \mathrm{AR}$ ) for the compounds described above.

Considering the compounds presenting only small para-substituents on the 6-phenyl ring (12-14, 18, 19), the $h A_{2 A} A R$ affinities appear significantly higher than the $h A_{1} A R$ ones. The different affinity for the two AR subtypes could be due to both the chemical-physical profile of the AR residues in proximity of the substituent and how much the substituent itself is exposed to the external environment. Figure 6A-B shows a surface representation of the entrance of the binding cavities, in proximity to the para-position of the 6-phenyl ring. The light-to-dark regions indicate a hydrophobic-to-hydrophilic profile of the residues. The more polar profile of the $\mathrm{hA}_{1} \mathrm{AR}$ residues with respect to the $\mathrm{hA}_{2 \mathrm{~A}} \mathrm{AR}$ ones is due in particular to the presence of a negatively charged glutamate residue (Glu170, Figure $5 \mathrm{~B}$ ) in $\mathrm{hA}_{1} \mathrm{AR}$, while the $\mathrm{hA}_{2 \mathrm{~A}} \mathrm{AR}$ bears a non-polar leucine (Leu167, Figure 4B) in the same position. The presence of Glu170 in $\mathrm{hA}_{1} \mathrm{AR}$ leads to a repulsive effect between this residue and the carbonyl group of the compounds bearing a carboxyamidoethyl spacer $(\mathbf{1 9}, \mathbf{2 0}, \mathbf{2 1})$. This effect is evident from the comparison of the activities of the latter compounds with the higher affinity data at the $\mathrm{hA}_{1} \mathrm{AR}$ of the corresponding analogues bearing an oxyethyl spacer $\left(\mathbf{1 4}, \mathbf{1 5}, \mathbf{1 6}\right.$, respectively). At the $\mathrm{hA}_{2 \mathrm{~A}} \mathrm{AR}$, both the carboxyamidoethyl and oxyethyl spacers generally lead to nanomolar affinities. 

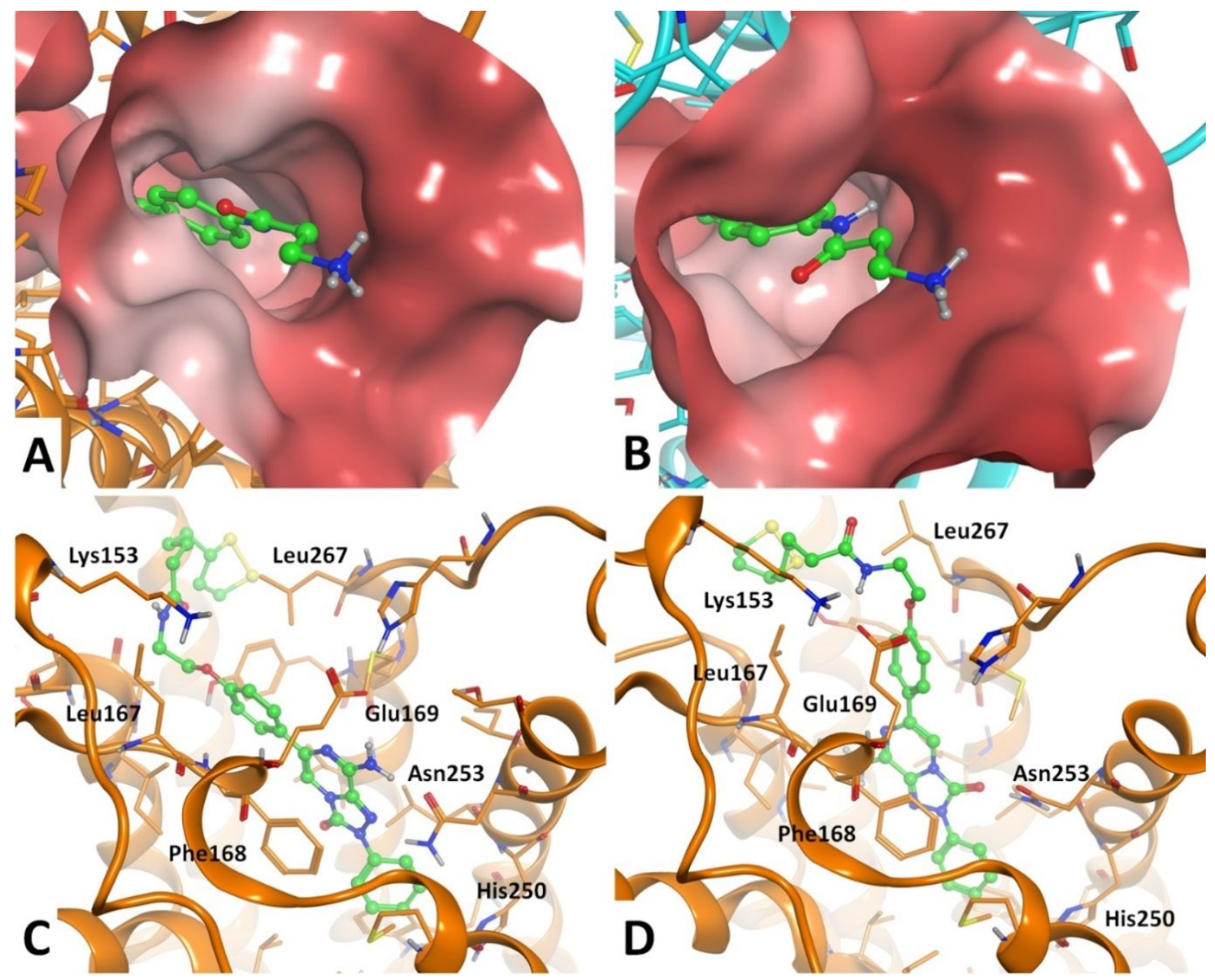

Figure 6. A-B Top-view of the binding mode of compound 19 at the $\mathrm{hA}_{2 \mathrm{~A}} \mathrm{AR}(\mathrm{A}, \mathrm{pdb}$ : $5 \mathrm{NM} 4)$ and $\mathrm{hA}_{1} \mathrm{AR}$ (B pdb: 5N2S) binding sites. Molecular surface representations of both binding cavities are represented. Light-to-dark colors of surface correspond to hydrophobic-to-hydrophilic regions. CD. Binding modes suggested for compounds bearing large para-substituents in the 6-phenyl ring; compound 15 at the $\mathrm{hA}_{2 \mathrm{~A}} \mathrm{AR}$ (pdb: 5NM4) is shown. These molecules may adopt the general binding mode above described $(\mathbf{C})$ or an alternative, energetically more stable, docking conformation that makes the para-substituent externally oriented without clashes with receptor residues $(\mathrm{D})$.

Docking studies performed for the compounds presenting small para-substituents $(\mathbf{1 2 - 1 4}, \mathbf{1 8}, \mathbf{1 9})$ show that these molecules may adopt a binding mode similar to the one described above. The 
interaction of the para-substituent with $\mathrm{hA}_{2 \mathrm{~A}} \mathrm{AR}$ residues is modulated by the chemical-physical profile of the substituent itself and the receptor residues in proximity. The positively charged amine function of compound $\mathbf{1 9}$ gets located in proximity of both the hydroxyl group of Tyr271 7.36 and the carbonyl group of Ser67 2.65 (Figures 4B and 6A), thus providing subnanomolar affinity for the hA $\mathrm{A}_{2 \mathrm{~A}}$ AR. Compounds bearing a large para-substituent $(\mathbf{1 5 - 1 7}, \mathbf{2 0 - 2 1})$ may adopt as well as the abovedescribed binding mode (Figure 6C, compound 15), even if the large para-substituent gets located too close to the receptor residues, giving a steric clash with the protein atoms. Docking results for these compounds suggest also an alternative binding mode, with the bicyclic scaffold upside-down oriented to point the 3-carbonyl group toward the amine function of Asn253 ${ }^{6.55}$ (Figure 6D, compound 15). This binding mode lacks some hydrophilic interactions with the receptor that are observed in the general compound orientation described above (i.e. with Glu169 at hA $2 \mathrm{AR}$ ); on the other hand, the alternative binding mode favors the pointing of the para-substituent toward the external environment with a more energetically stable compound conformation. This may explain the favorable docking scores obtained by the alternative binding mode arrangement for compounds bearing large para-substituents in the 6-phenyl ring. Considering the largest compounds $(\mathbf{1 5}, \mathbf{1 6}, \mathbf{2 0}$, 21), the lowest activity belongs to derivative 16, which is the one presenting a para-substituent of large volume and the shortest oxyethylamino spacer linking the 6-phenyl ring. In contrast, its corresponding analogue with the longer carboxyamidoethyl spacer (21) presents a 300-fold improvement of the $\mathrm{hA}_{2 \mathrm{~A}} \mathrm{AR}$ affinity. On the other hand, both derivatives presenting a less bulky lipoyl group (15 and 20) are endowed with significantly higher affinity. This suggests that the length and volume of the large para-substituents appear critical for the receptor affinity, for an energetically stable accommodation of the substituent itself within the receptor residues.

Neuroprotection Studies on oxaliplatin-induced neurotoxicity in microglia cells. Based on the affinity data, compounds $\mathbf{1 1}, \mathbf{1 2}, \mathbf{1 5}, \mathbf{2 0}$ and $\mathbf{2 1}$, potent and selective $\mathrm{hA} 2 \mathrm{~A} A \mathrm{R}$ antagonists, were 
selected for further pharmacological evaluation. In particular, their protective effect against the neurotoxicity of the anticancer drug oxaliplatin on rat microglia cells was determined. Neuropathy induced by oxaliplatin is a common side effect in patients treated with this drug and consists in paresthesia, dysesthesia, and pain. Such a condition adversely affects quality of life and can lead to discontinuation of therapy. ${ }^{56}$ It is well-known that glia cells play a key role in the CNS homeostasis and are strongly involved in the responses to nerve injury. Microglia and astrocytes activate several mechanisms, such as production of trophic factors, regulation of transmitter and ion concentrations, which tend to decrease neuronal injury. Nevertheless, in pathological conditions, the maladaptive plasticity of glial cells strongly sustains negative symptoms like chronic pain. In particular, microglia functional modifications have the potential to induce neuronal dysfunction, playing a pivotal role in oxaliplatin neuropathy development..$^{57,58}$

The selected compounds were chosen taking into account their high affinity and selectivity toward the $\mathrm{hA}_{2 \mathrm{~A}} \mathrm{AR}$ but also the presence in all of them, except compound 12, of antioxidant moieties which were thought to counteract oxaliplatin neurotoxicity. In fact, although the molecular basis underlying the oxaliplatin neuropathy is unclear, some experimental evidence pointed out a correlation between oxidative stress damage and neuropathic pain onset, ${ }^{20}$ also highlighting efficacy of the antioxidant silibinin and $\alpha$-tocopherol in reducing oxaliplatin-dependent pain induced by mechanical and thermal stimuli. ${ }^{59}$ Compound 12, lacking the antioxidant portion, was tested to evaluate how the lone blockade of the $\mathrm{A}_{2 \mathrm{~A}} \mathrm{AR}$ could affect oxaliplatin toxicity.

Primary rat microglia cells were treated with oxaliplatin in the absence or in the presence of the tested compounds. Oxaliplatin damage was evaluated as cell viability and oxidative stress, the latter previously described as the main damage evoked by oxaliplatin. ${ }^{60}$ The new synthesized compounds were tested at $10 \mu \mathrm{M}$, the maximum soluble concentration. Oxaliplatin, concentration-dependently, strongly reduced microglia viability (MTT test) after $24 \mathrm{~h}$ incubation (33\% and 19\% viability with 10 and $30 \mu \mathrm{M}$, respectively, in comparison to $100 \%$ of control condition). 
The obtained results showed that the lipoic acid-conjugated derivative $\mathbf{1 5}$ was the most active in preventing the oxaliplatin damage, also when incubated at the high oxaliplatin concentration (30 $\mu \mathrm{M})$. Compound 12 was instead effective against $10 \mu \mathrm{M}$ oxaliplatin. Regarding the other tested compounds, the 6-phenol derivatives $\mathbf{1 1}$ and $\mathbf{2 1}$ showed partial activity at both oxaliplatin concentrations, whereas the lipoic derivative 20, contrary to our expectations, turned out to be ineffective (Table 4). This latter result might be due to a possible instability of $\mathbf{2 0}$ in the microglia assay medium, as reported in the "Chemical stability study" section.

Table 4. Compound effects on microglial cell viability ${ }^{\mathrm{a}}$

\begin{tabular}{llll}
\hline & \multicolumn{3}{c}{ Cell viability (\%) } \\
\hline & Oxa 0 $\boldsymbol{\mu M}$ & Oxa 10 $\boldsymbol{\mu M}$ & Oxa 30 $\boldsymbol{\mu M}$ \\
Control & $100.0 \pm 7$ & $33.2 \pm 1.3^{* *}$ & $19.1 \pm 0.8^{* *}$ \\
DMSO $0.75 \%$ & $90.9 \pm 8$ & & \\
$\mathbf{1 1} 10 \mu \mathrm{M}$ & & $46.4 \pm 1.4^{\wedge \wedge}$ & $28.6 \pm 1.21^{\wedge}$ \\
$\mathbf{1 2} 10 \mu \mathrm{M}$ & & $48.7 \pm 0.8^{\wedge}$ & $23.0 \pm 0.9$ \\
$\mathbf{1 5} 10 \mu \mathrm{M}$ & & $54.5 \pm 1.9^{\wedge \wedge}$ & $34.2 \pm 0.60^{\wedge}$ \\
$\mathbf{2 0} 10 \mu \mathrm{M}$ & & $38.9 \pm 1.6$ & $18.3 \pm 0.3$ \\
$\mathbf{2 1} 10 \mu \mathrm{M}$ & & $43.5 \pm 1.8^{\wedge}$ & $30.6 \pm 2.2^{\wedge}$ \\
\hline
\end{tabular}

a Primary rat microglia cells were plated 4000 cells/well and 24 hours later cells were treated with oxaliplatin (Oxa) 10 and $30 \mu \mathrm{M}$ in presence of 11, 12, 15, 20 and 21 at $10 \mu \mathrm{M}$ for 24 hours. Cell vitality was assessed via MTT assay. Viability is expressed as \% in comparison to the control cells (arbitrarily set $100 \%$ of viable cells). Data are presented as mean \pm SEM of three experiments. ${ }^{*} \mathrm{P}<0.05$ and ${ }^{* *} \mathrm{P}<0.01$ versus control; ${ }^{\wedge} \mathrm{P}<0.05$ and ${ }^{\wedge} \wedge \mathrm{P}<0.01$ versus oxaliplatin.

Further investigations were carried out on these compounds by evaluating their ability to prevent the oxaliplatin-dependent increase of the SOD-inhibitable superoxide anion (cytochrome C assay). According to the obtained data, compounds $\mathbf{1 5}$ and $\mathbf{2 1}$ proved to be effective in significantly 
decreasing the oxygen free radical level thus suggesting a direct antioxidant activity or, hypothetically, a protective property against mitochondrion (Figure 7).

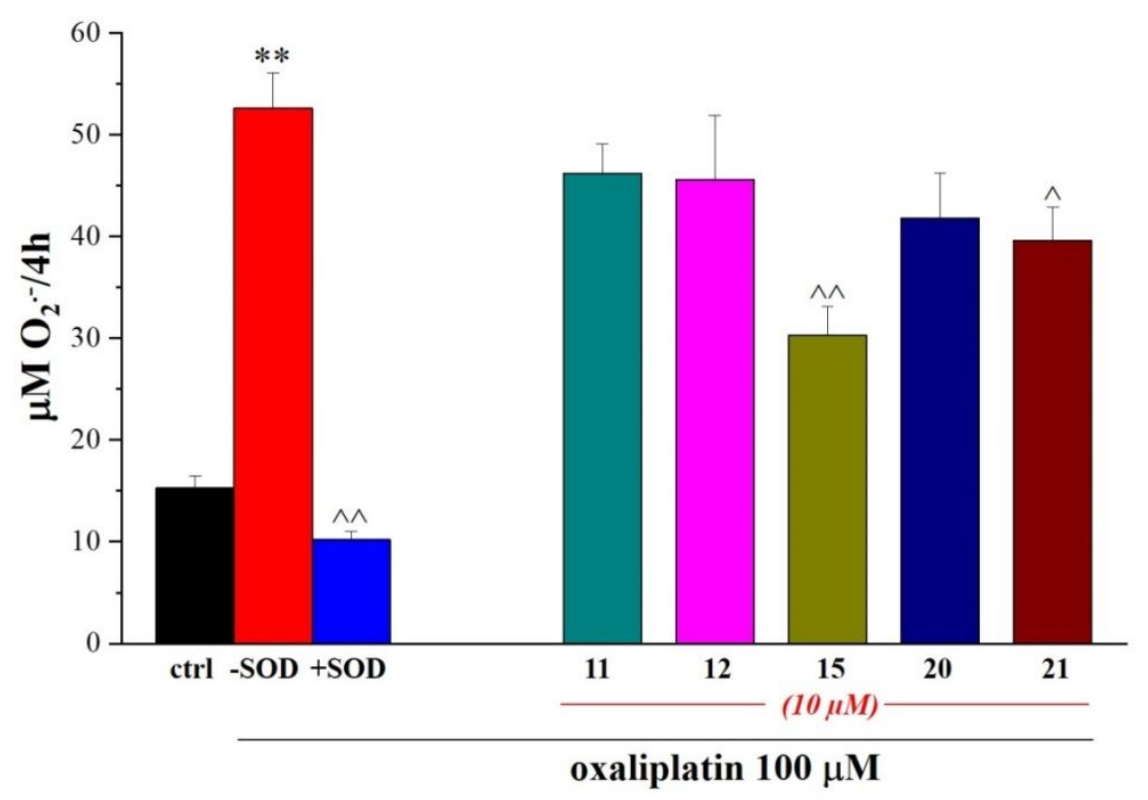

Figure 7. Compound effects on SOD-inhibitable $\mathrm{O}_{2}{ }^{--}$concentrations in rat microglia cells. Microglia cells $\left(5 \times 10^{5}\right.$ cells/well) were exposed to $100 \mu \mathrm{M}$ oxaliplatin for $4 \mathrm{~h}$ in the absence or presence of tested compounds $(10 \mu \mathrm{M}) . \mathrm{O}_{2}{ }^{-}$concentration was evaluated by cytochrome $c$ assay. The nonspecific absorbance was measured in the presence of SOD $(300 \mathrm{mU} / \mathrm{ml})$ and subtracted from the total value. Values are expressed as the mean \pm SEM of three experiments. ${ }^{*} \mathrm{P}<0.05$ and $* * \mathrm{P}<0.01$ versus control; ${ }^{\wedge} \mathrm{P}<0.05$ and ${ }^{\wedge} \wedge \mathrm{P}<0.01$ versus oxaliplatin.

The activity of the detoxifying enzyme catalase was also measured to study the potential effect of new compounds on peroxisomes, the other intracellular organelle involved in the redox balance. As shown in Figure 8, oxaliplatin impaired peroxisome functionality, reducing catalase activity while 15 and 21 significantly prevented the damage. 


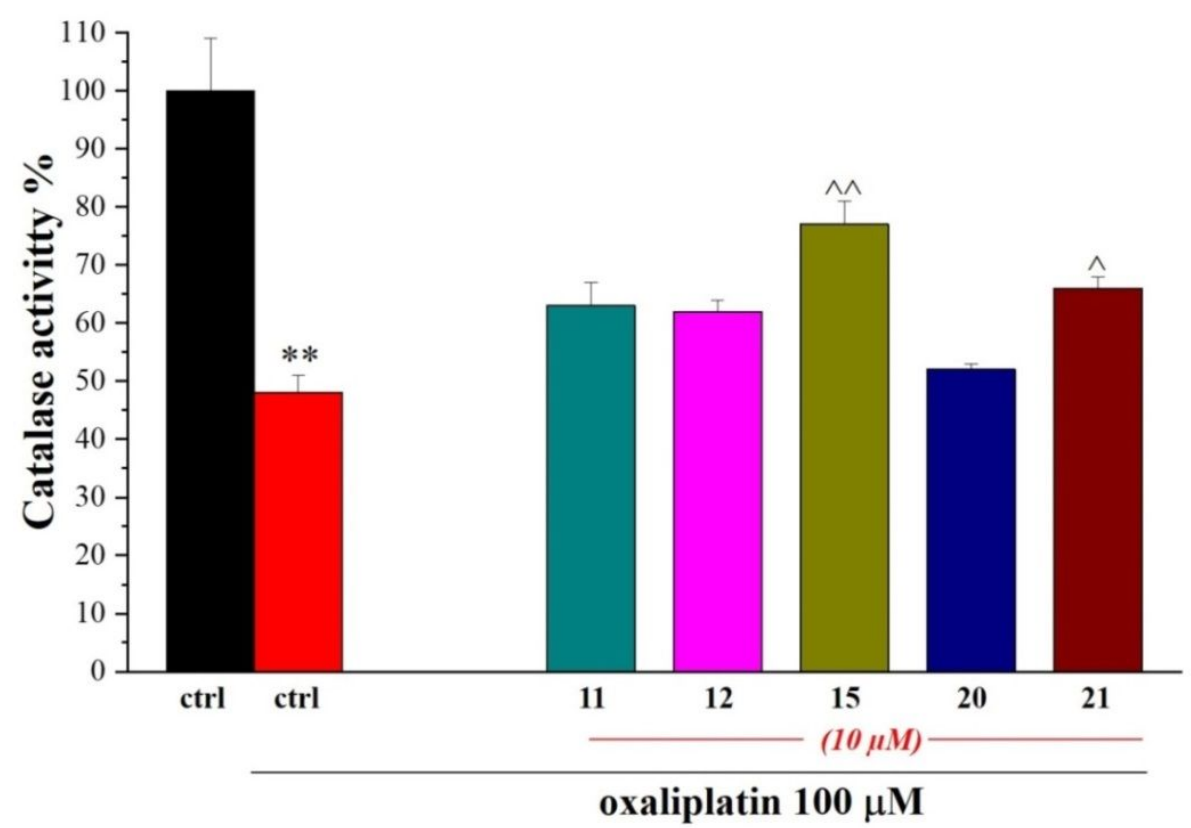

Figure 8. Compound effects on catalase activity. Microglia cells $\left(5 \cdot 10^{5}\right.$ cells/well $)$ were treated with oxaliplatin $(10 \mu \mathrm{M})$ in the absence or in the presence of the new compounds $(10 \mu \mathrm{M})$. Activity was measured after $24 \mathrm{~h}$ incubations. Values are expressed as the mean \pm S.E.M. of three experiments. Control condition was arbitrarily set as $100 \%$. $* \mathrm{P}<0.05$ and $* * \mathrm{P}<0.01$ versus control; ${ }^{\wedge} \mathrm{P}<0.05$ and ${ }^{\wedge} \wedge \mathrm{P}<0.01$ versus oxaliplatin.

Behavioral studies in the oxaliplatin-induced neuropathy model. On the basis of the results obtained from in vitro tests, we selected compounds 12, 15 and $\mathbf{2 1}$ for an in vivo study in a mouse model of oxaliplatin-induced neuropathy. On day 14, after a repeated treatment with the anticancer drug injected at a clinically-relevant dose,${ }^{61}$ the hypersensivity to a cold non noxious stimulus (cold plate test) was significantly established (Figure 9). The pain-relieving effects of new synthesized compounds were tested after a single per os administration. Compounds $\mathbf{1 2}$ and 21 (10 and $30 \mathrm{mg}$ $\mathrm{kg}^{-1}$ ) were able to increase the pain threshold between 15 and 45 min after treatment. Interestingly, compound 15 induced significant relieving effects starting from the $0.03 \mathrm{mg} \mathrm{kg}^{-1}$ dose. The efficacy, dose-dependently, increased till it completely reverted oxaliplatin-induced neuropathic 
pain when administered at 1 and $10 \mathrm{mg} \mathrm{kg}^{-1}$. The effect of $\mathbf{1 5}$ began $30 \mathrm{~min}$ after treatment, and the compound was still fully active at $60 \mathrm{~min}$. In the same model, lipoic acid, administered per os at an equimolar dose (4 mg kg-1) to $10 \mathrm{mg} \mathrm{kg}^{-1}$ of compound 15 , was completely inactive. Also when tested at 10-fold higher dose (40 $\left.\mathrm{mg} \mathrm{kg}^{-1}\right)$, lipoic acid was ineffective (Figure 9).
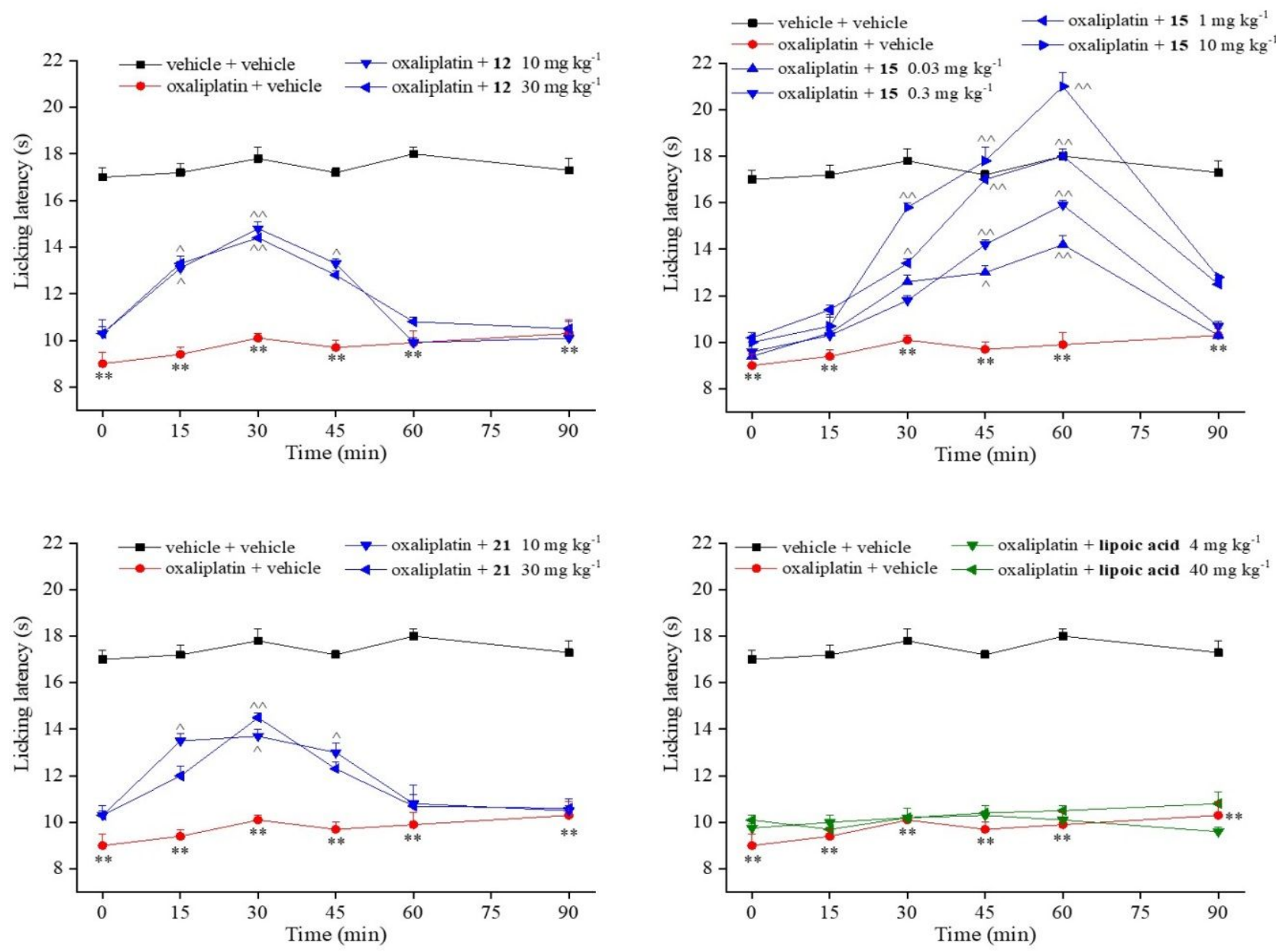

Figure 9. Compound effects against neuropathic pain. Mice were repeatedly treated with oxaliplatin (2.4 mg kg-1; dissolved in 5\% glucose solution and i.p. administered). On day 14 , compounds were suspended in carboxymethylcellulose and administered p.o. Pain-related behavior (i.e. lifting and licking of the hind paw) was observed and the time (in seconds) of the first sign was recorded. ${ }^{* *} \mathrm{P}<0.01$ vs vehicle + vehicle treated animals; ${ }^{\wedge} \mathrm{P}<0.05$ and ${ }^{\wedge} \wedge \mathrm{P}<0.01$ vs oxaliplatin + vehicle treated animals. Each value represents the mean of 10 mice performing in two different experimental sets. 
The significant difference between the potency of the lipoic-conjugated triazolopyrazine $\mathbf{1 5}$ and lipoic acid could be due both to diverse pharmacokinetic properties of the two compounds and to the presence of the $\mathrm{hA}_{2 \mathrm{~A}} \mathrm{AR}$ antagonist component in derivative 15. This hypothesis is supported by data obtained in different animal model of neuroprotection ${ }^{37,59,60}$ indicating that lipoic acid is well absorbed per os but is subject to pre-systemic elimination by the liver, and in rat only about 27 $34 \%$ lipoic acid administered orally is available for absorption by the tissue. ${ }^{59}$ Moreover, the complexity of neuropathic pain signaling does not allow consideration of the redox imbalance as the unique pathological signature. ${ }^{54}$ The importance of the $\mathrm{hA}_{2 \mathrm{~A}} \mathrm{AR}$ antagonist component in reducing oxaliplatin-induced neuropathy is underlined by the pain-relieving effect of compound 12, lacking the antioxidant portion. It is worth noting that the lipoic-conjugated compound $\mathbf{1 5}$, showing the best activity in the microglia assays, was the most active also in this in vivo model. Hence, we hypothesized that these findings might be ascribed, at least in part, to the higher affinity of compound $\mathbf{1 5}$ for the $\mathrm{A}_{2 \mathrm{~A}} \mathrm{AR}$ in rodents, with respect to those of $\mathbf{1 2}$ and $\mathbf{2 1}$, as could be envisaged on the basis of the $A_{2 A} A R$ affinities obtained for the human species (Table 2). To confirm our prediction, binding studies at the rat $(r) A_{2 A} A R$ were carried out on the three derivatives. The achieved results (Table 5) confirmed the expected trend, because the lipoic derivative $\mathbf{1 5}$ displayed the highest binding value, being about 4-fold and 10-fold more active than compounds $\mathbf{1 2}$ and $\mathbf{2 1}$, respectively.

Table 5. Binding activity of compounds 12, 15, 21, and ZM241385 as reference ligand, at $\mathrm{rA}_{2 \mathrm{~A}}$ AR. ${ }^{\mathrm{a}}$

\begin{tabular}{cc}
\hline & $\mathrm{rA}_{2 \mathrm{~A}} \mathrm{~K}_{\mathrm{i}} \mathrm{nM}^{\mathrm{b}}$ \\
\hline $\mathbf{1 2}$ & $39 \pm 5.6$ \\
$\mathbf{1 5}$ & $9 \pm 1.7$ \\
$\mathbf{2 1}$ & $86 \pm 9.1$ \\
$\mathbf{Z M 2 4 1 3 8 5}$ & $2.8 \pm 0.3$ \\
\hline
\end{tabular}




\begin{abstract}
aData $(n=3-5)$ are expressed as means \pm standard errors. bisplacement of specific $\left[{ }^{3} \mathrm{H}\right]-\mathrm{NECA}$ binding at $\mathrm{rA}_{2 \mathrm{~A}} \mathrm{AR}$ expressed in $\mathrm{CHO}$ cells.
\end{abstract}

\begin{abstract}
Obviously, besides the different $\mathrm{rA}_{2 \mathrm{~A}}$ AR affinity, other molecular features, such as the antioxidant character and the pharmacokinetic properties, can be responsible of the diverse in vivo activity of these triazolopyrazines. The higher potency of derivative $\mathbf{1 5}$, compared to $\mathbf{2 1}$, suggests that the lipoic acid residue, with respect to the BHT-analogue group, might confer enhanced in vivo properties, for both its antioxidant activity and its positive effect on pharmacokinetics. To address this issue further studies have been planned to gain more insight into the interesting protective profile of compound $\mathbf{1 5 .}$
\end{abstract}

Chemical stability study. Compounds 11, 12, 15, 20 and 21, selected for pharmacological evaluation, feature antioxidant moieties, amide functions, or a cyano group. All these functionalities might have some lability, hence we thought it interesting to ascertain their stability towards spontaneous or enzymatic degradation in $50 \mathrm{mM}$ tris(hydroxymethyl)aminomethane hydrochloride buffer solution (50 mM Tris buffer, $\mathrm{pH}=7.4$ ) and human plasma, respectively.

The instrumental conditions are reported in the Experimental Procedure section.

The solution stability of each studied compound was verified by monitoring the variation of its concentration at different incubation times in $50 \mathrm{mM}$ Tris buffer and human plasma samples. By plotting these data (natural logarithm of analyte concentration versus the incubation time) the respective degradation profiles were obtained (Figures 10 and 11 and Figures 1S-4S in Supporting Information) which demonstrated that all the compounds were stable in $50 \mathrm{mM}$ Tris buffer and most of them also in human plasma. In fact, only the degradation plots of the 6-(3-ter-butyl-4hydroxyphenyl) derivative 11 and the lipoyl derivative 20 (Figures 10 and 11) in human plasma 
showed a significant decay rate ( $\mathrm{k}$ value, defined in Supporting Information) and their calculated half-life values $\left(\mathrm{t}_{1 / 2}\right)$ are $122 \pm 4 \mathrm{~min}$ and $41 \pm 13 \mathrm{~min}$ respectively, as displayed in Table 4 .

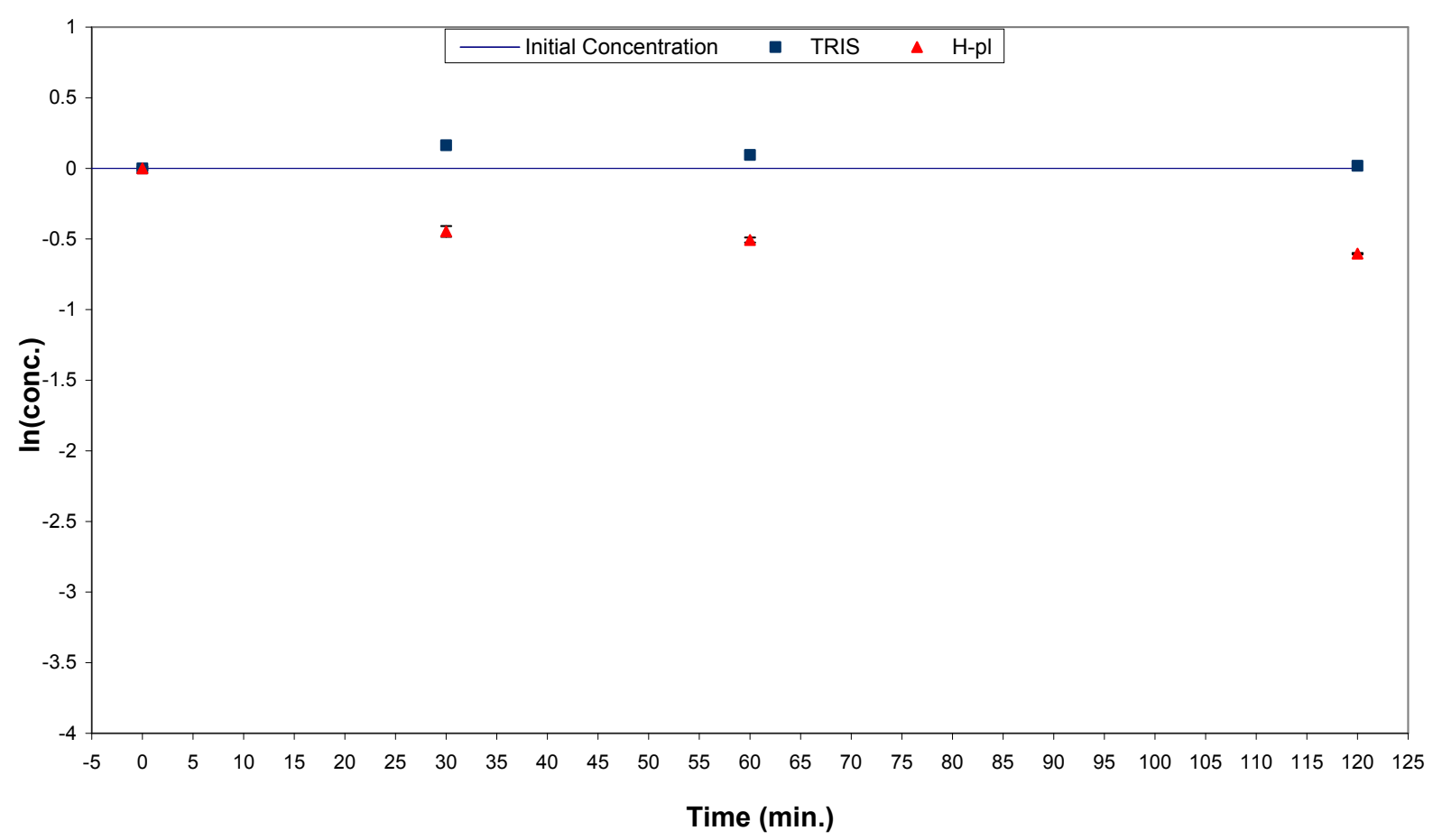

Figure 10. Degradation plots of compound 11 in $50 \mathrm{mM}$ Tris buffer solution (blue square) and human plasma (red triangle). 


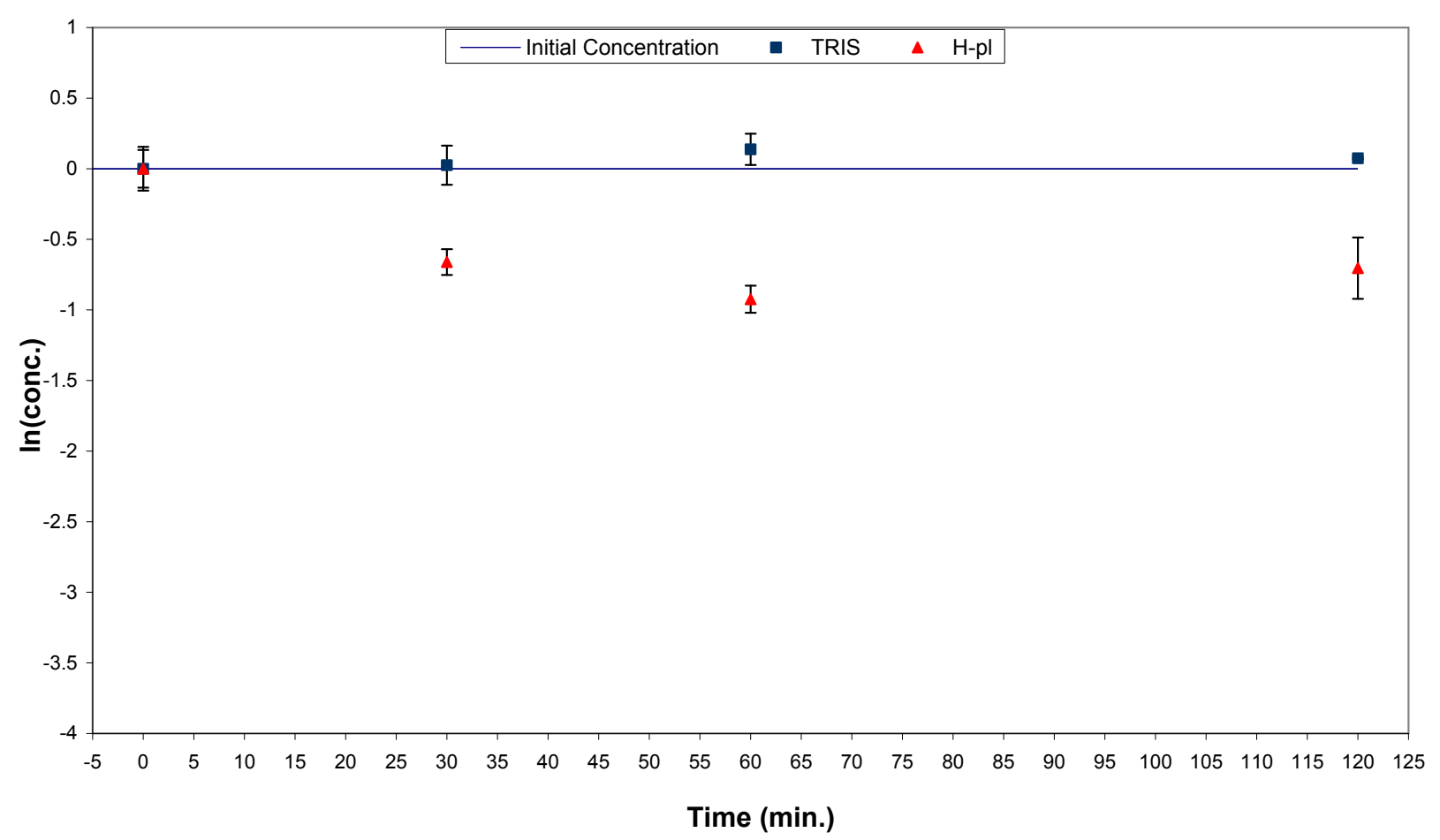

Figure 11. Degradation plots of compound 20 in $50 \mathrm{mM}$ Tris buffer solution (blue square) and human plasma (red triangle).

The half-life value of ketoprofene ethylester (KEE), used as reference compound, demonstrated that the employed human batch was enzymatically active (half-life $<2 \mathrm{~h}$ ). ${ }^{64}$ The $\mathrm{k}$ values of the stable compounds were close to 0 ; consequently for these derivatives, extremely high $t_{1 / 2}$ values can be calculated. Since under the proposed experimental conditions a half-life over $240 \mathrm{~min}$ is not correctly evaluated, it is reasonable to consider that their half-life values could be equal to or greater than $240 \mathrm{~min}$. The $50 \mathrm{mM}$ Tris buffer and human plasma half-lifes of other studied compounds are reported in Table 5.

Table 5. Half-life $\left(\mathrm{t}_{1 / 2}\right)$ of studied compounds in $50 \mathrm{nM}$ Tris buffer and human plasma samples.

\begin{tabular}{ll}
\hline $50 \mathrm{mM}$ Tris buffer & Human-plasma \\
$\mathrm{t}_{1 / 2} \pm$ error $(\min )$ & $\mathrm{t}_{1 / 2} \pm$ error $(\min )$ \\
\hline
\end{tabular}




\begin{tabular}{lll}
\hline KEE & $\mathrm{nd}^{\mathrm{a}}$ & $107 \pm 16$ \\
$\mathbf{1 1}$ & $\geq 240$ & $122 \pm 4$ \\
$\mathbf{1 2}$ & $\geq 240$ & $\geq 240$ \\
$\mathbf{1 5}$ & $\geq 240$ & $\geq 240$ \\
$\mathbf{2 0}$ & $\geq 240$ & $41 \pm 13$ \\
$\mathbf{2 1}$ & $\geq 240$ & $\geq 240$ \\
\hline
\end{tabular}

${ }^{a}$ not determined

To summarize, these experiments demonstrated that the tested compounds did not suffer significant degradation process under the proposed conditions. Only derivatives $\mathbf{1 1}$ and $\mathbf{2 0}$ showed a clear degradation rate in human plasma, but with large different of $t_{1 / 2}$ values $(122 \pm 4$ and $41 \pm 13$ respectively). The behavior of $\mathbf{2 0}$ might suggest a possible explanation of its inactivity on microglia cell viability test, where all the other compounds proved to be effective. Hence, inactivity of $\mathbf{2 0}$ might be partly ascribed to its possible decomposition in the microglia assay medium.

\section{CONCLUSION}

This study has produced new highly potent and selective antagonists for the $\mathrm{hA}_{2 \mathrm{~A}} \mathrm{AR}$, some of which possess hindering antioxidant functions. Insertion of these functions on the 6-aryl group, notwithstanding their high steric bulk, maintained a nanomolar $\mathrm{hA}_{2 \mathrm{~A}} \mathrm{AR}$ affinity and high selectivity. Molecular docking studies highlighted that the 6-aryl moiety of these new triazolopyrazines is positioned at the entrance of the $\mathrm{hA}_{2 \mathrm{~A}} \mathrm{AR}$ binding site and that both lipophilicity and the volume of the substituent inserted on this ring modulate affinity and selectivity. On the whole, non-polar para-substituents are more efficient than polar groups in improving $\mathrm{hA}_{2 \mathrm{~A}}$ receptor-ligand interaction due to the presence of non-polar amino acid residues surrounding the 6aryl pendant. Further pharmacological studies were carried out on selected triazolopyrazines showing high $\mathrm{hA}_{2 \mathrm{~A}}$ affinity and selectivity. Compounds 11, 15 and 21, featuring antioxidant 
moieties, and compound 12, lacking the antioxidant functionality, reduced oxaliplatin-induced toxicity in microglia cells, the most active being the lipoyl derivative $\mathbf{1 5}$. This compounds and, to a lesser extent, the BHT analogue $\mathbf{2 1}$ proved to be effective in reducing the oxygen free radical level, thus suggesting a direct antioxidant activity. Derivatives 12, 15 and 21, further investigated in vivo, were able to reduce oxaliplatin-induced neuropathy in mouse. Also in these tests, the lipoylderivative 15 displayed the best results, being able to completely revert oxaliplatin-induced pain when administered at 1 and $10 \mathrm{mg} \mathrm{kg}^{-1}$. The in vivo efficacy of derivative $\mathbf{1 5}$ makes it a promising neuroprotective candidate in oxidative stress-related pathologies.

\section{EXPERIMENTAL PROCEDURE}

Chemistry. The microwave-assisted syntheses were performed using an Initiator EXP Microwave Biotage instrument (frequency of irradiation: $2.45 \mathrm{GHz})$. Analytical silica gel plates $(0.20 \mathrm{~mm}$, F254, Merck, Germany) and silica gel 60 (Merck, 70-230 mesh) was used for analytical and column chromatography, respectively. All melting points were determined on a Gallenkamp melting point apparatus and are uncorrected. Elemental analyses were performed with a Flash E1112 Thermofinnigan elemental analyzer for $\mathrm{C}, \mathrm{H}, \mathrm{N}$ and the results were within $0.4 \%$ of the theoretical values. All final compounds revealed purity not less than 95\%. The IR spectra were recorded with a Perkin-Elmer Spectrum RX I spectrometer in Nujol mulls and are expressed in $\mathrm{cm}^{-1}$. NMR spectra were recorded on a Bruker Avance 400 spectrometer (400 MHz for ${ }^{1} \mathrm{H}$ - and $100 \mathrm{Mz}$ for ${ }^{13} \mathrm{C}-\mathrm{NMR}$ ). The chemical shifts are reported in $\delta(\mathrm{ppm})$ and are relative to the central peak of the solvent which was $\mathrm{CDCl}_{3}$ or $\mathrm{DMSOd}_{6}$. The following abbreviations are used: $\mathrm{s}=$ singlet, $\mathrm{d}=$ doublet, $\mathrm{t}=$ triplet, $\mathrm{q}=$ quartet, $\mathrm{m}=$ multiplet, $\mathrm{br}=$ broad and ar= aromatic protons. The high resolution mass spectrometry (HRMS) analysis was performed with a Thermo LTQ Orbitrap mass spectrometer equipped with an electrospray ionization source (ESI). The analysis were carried out in positive ion mode monitoring the $[\mathrm{M}+\mathrm{H}]^{+}$species by using a proper dwell time acquisition to achieve 60,000 resolving power 
units at Full Width at Half Maximum of the $\mathrm{m} / \mathrm{z}$ signal. Elemental composition of compounds were calculated on the basis of their measured accurate masses, accepting only results with an attribution error less than $5 \mathrm{ppm}$ and a not integer double bond/ring equivalents value, in order to consider only the protonated species. ${ }^{65}$

Compounds were named following IUPAC rules as applied by ChemDrawUtra 9.0.

\section{General procedure for the synthesis of 8-Amino-6-aryl-2-phenyl-1,2,4-triazolo[4,3-a]pyrazin-} 3(2H)-ones (1-6). A suspension of the 8-chloro-triazolopyrazine derivatives $43-48$ (1.0 mmol), in a saturated ethanolic solution of $\mathrm{NH}_{3}(50 \mathrm{~mL})$, was heated at $140{ }^{\circ} \mathrm{C}$ in a sealed tube for $16 \mathrm{~h}$. The mixture was cooled at rt, the suspended solid was collected by filtration, washed with water (about 5-10 mL), and purified by recrystallization or column chromatography.

8-Amino-6-(2,4-dimethoxyphenyl)-2-phenyl-1,2,4-triazolo[4,3-a]pyrazin-3 (2H)-one (1). Yield 43\%; mp 255-257 ${ }^{\circ} \mathrm{C}\left(\right.$ EtOH/2-methoxyethanol). ${ }^{1} \mathrm{H}$ NMR (DMSO-d 6 ) 8.07 (d, 2H, ar, J = 8.4 Hz), $8.02(\mathrm{~d}, 1 \mathrm{H}, \mathrm{ar}, \mathrm{J}=8.6 \mathrm{~Hz}), 7.80(\mathrm{~s}, 1 \mathrm{H}, \mathrm{H}-5), 7.57$ (t, 2H, ar, J = 8.4 Hz), 7.43 (br s, 2H, $\left.\mathrm{NH}_{2}\right), 7.35$ $(\mathrm{t}, 1 \mathrm{H}, \mathrm{ar}, \mathrm{J}=7.4 \mathrm{~Hz}), 6.64-6.68(\mathrm{~m}, 2 \mathrm{H}, \mathrm{ar}), 3.92\left(\mathrm{~s}, 3 \mathrm{H}, \mathrm{CH}_{3}\right), 3.82\left(\mathrm{~s}, 3 \mathrm{H}, \mathrm{CH}_{3}\right)$. Anal. Calcd for $\mathrm{C}_{19} \mathrm{H}_{17} \mathrm{~N}_{5} \mathrm{O}_{3}$ : C, 62.80; H, 4.72; N,19.27. Found: C, 62.67; H, 4.68; N, 19.36. ESI-HRMS (m/z) calculated for $[\mathrm{M}+\mathrm{H}]^{+}$364.1404, found 364.1409.

8-Amino-6-(3,4-dimethoxyphenyl)-2-phenyl-1,2,4-triazolo[4,3-a]pyrazin-3(2H)-one (2). Yield 65\%; mp 212-214 ${ }^{\circ} \mathrm{C}\left(\right.$ EtOH/2-methoxyethanol). ${ }^{1} \mathrm{H}$ NMR (DMSO-d $\left.{ }_{6}\right) 8.08(\mathrm{~d}, 2 \mathrm{H}$, ar J = $7.7 \mathrm{~Hz})$, $7.76(\mathrm{~s}, 1 \mathrm{H}, \mathrm{H}-5), 7.52-7.58\left(\mathrm{~m}, 5 \mathrm{H}, 3 \mathrm{ar}+\mathrm{NH}_{2}\right), 7.36(\mathrm{t}, 1 \mathrm{H}, \mathrm{ar}, \mathrm{J}=7.4 \mathrm{~Hz}), 7.00(\mathrm{~d}, 2 \mathrm{H}, \mathrm{ar}, \mathrm{J}=8.4$ $\mathrm{Hz}), 3.86\left(\mathrm{~s}, 3 \mathrm{H}, \mathrm{OCH}_{3}\right), 3.80\left(\mathrm{~s}, 3 \mathrm{H}, \mathrm{OCH}_{3}\right) .{ }^{13} \mathrm{C}-\mathrm{NMR}\left(\mathrm{DMSO}-\mathrm{d}_{6}\right)$ 149.42, 149.20, 147.63, $137.99 ; 135.92,131.54,129.64,129.57,126.72,119.85,118.63,112.05,109.59,100.99,56.09$, 55.98. IR 3348, 3340-3300, 1714, 1699. Anal. Calcd for $\mathrm{C}_{19} \mathrm{H}_{17} \mathrm{~N}_{5} \mathrm{O}_{3}$ : C, 62.80; H, 4.72; N, 19.27. 
Found: C, 62.98; H, 4.83; N, 19.45. ESI-HRMS $(\mathrm{m} / \mathrm{z})$ calculated for $[\mathrm{M}+\mathrm{H}]^{+} 364.1404$, found 364.1407.

8-Amino-6-(3,4-methylendioxyphenyl)-2-phenyl-1,2,4-triazolo[4,3-a]pyrazin-3(2H)-one

Yield 96\%; mp $>300{ }^{\circ} \mathrm{C}(\mathrm{AcOH} / \mathrm{DMF}) .{ }^{1} \mathrm{H}$ NMR $\left(\mathrm{DMSO}_{6}\right) 8.07$ (d, 2H, ar, J = $\left.7.8 \mathrm{~Hz}\right), 7.72(\mathrm{~s}$, 1H, H-5), 7.54-7.58 (m, 6H, 4ar + $\left.\mathrm{NH}_{2}\right), 7.35(\mathrm{t}, 1 \mathrm{H}, \mathrm{ar}, \mathrm{J}=7.4 \mathrm{~Hz}), 6.96(\mathrm{~d}, 1 \mathrm{H}$, ar, J = $7.9 \mathrm{~Hz})$, $6.06\left(\mathrm{~s}, 2 \mathrm{H}, \mathrm{CH}_{2}\right) .{ }^{13} \mathrm{C}-\mathrm{NMR}\left(\mathrm{DMSO}_{6}\right)$ 148.12, 147.67, 147.63, 147.60, 137.97, 135.62, 131.54, $131.09,129.65,126.74,119.92,119.86,108.63,106.26,101.58,101.09$. Anal. Calcd for $\mathrm{C}_{18} \mathrm{H}_{13} \mathrm{~N}_{5} \mathrm{O}_{3}$ : C, 62.24; H, 3.77; N, 20.16. Found: C, 62.46; H, 3.54; N, 20.34. ESI-HRMS (m/z) calculated for $[\mathrm{M}+\mathrm{H}]^{+}$348.1091, found 348.1090.

\section{8-Amino-6-(3,4,5-trimethoxyphenyl)-2-phenyl-1,2,4-triazolo[4,3-a]pyrazin-3 (2H)-one (4).}

Yield 95\%; mp $231-232{ }^{\circ} \mathrm{C}$. Purified by column chromatography (eluent $\mathrm{CHCl}_{3}$ 9.5/MeOH 0.5). ${ }^{1} \mathrm{H}$ NMR (DMSO-d $\left.{ }_{6}\right) 8.08$ (d, 2H, ar, J = $\left.7.7 \mathrm{~Hz}\right), 7.90(\mathrm{~s}, 1 \mathrm{H}, \mathrm{H}-5)$, 7.56-7.58 (m, 4H, 2ar + NH $)_{2}$, $7.35(\mathrm{t}, 1 \mathrm{H}$, ar, $\mathrm{J}=7.4 \mathrm{~Hz}), 7.28\left(\mathrm{~s}, 2 \mathrm{H}\right.$, ar), $3.87\left(\mathrm{~s}, 6 \mathrm{H}, \mathrm{CH}_{3}\right), 3.70\left(\mathrm{~s}, 3 \mathrm{H}, \mathrm{CH}_{3}\right) .{ }^{13} \mathrm{C}-\mathrm{NMR}$ $\left(\right.$ DMSO-d $\left._{6}\right) 153.42,147.67,147.59,138.07,137.97,135.74,132.53,131.56,129.66,126.76$, 119.89, 103.48, 102.11, 60.53, 56.46. Anal. Calcd for $\mathrm{C}_{20} \mathrm{H}_{19} \mathrm{~N}_{5} \mathrm{O}_{4}$ : C, 61.06; H, 4.87; N, 17.80. Found: C, 61.24; H, 4.62; N, 17.98. ESI-HRMS $(\mathrm{m} / \mathrm{z})$ calculated for $[\mathrm{M}+\mathrm{H}]^{+} 394.1510$, found 394.1512.

\section{8-Amino-6-(4-methoxy-3,5-dimethylphenyl)-2-phenyl-1,2,4-triazolo[4,3-a]pyrazin-3(2H)-one}

(5). Yield 70\%; mp 228-229 ${ }^{\circ} \mathrm{C}(\mathrm{EtOH}) .{ }^{1} \mathrm{H}$ NMR (DMSO-d $\left.\mathrm{d}_{6}\right) 8.07$ (d, 2H, ar, J = $7.8 \mathrm{~Hz}$ ), 7.71$7.66(\mathrm{~m}, 3 \mathrm{H}, \mathrm{ar}), 7.58-7.54\left(\mathrm{~m}, 4 \mathrm{H}, \mathrm{ar}+\mathrm{NH}_{2}\right), 7.35(\mathrm{t}, 1 \mathrm{H}, \mathrm{ar}, \mathrm{J}=7.4 \mathrm{~Hz}), 3.68\left(\mathrm{~s}, 3 \mathrm{H}, \mathrm{CH}_{3}\right), 2.27$ $\left(\mathrm{s}, 6 \mathrm{H}, \mathrm{CH}_{3}\right) .{ }^{13} \mathrm{C}-\mathrm{NMR}\left(\mathrm{DMSO}_{-} \mathrm{d}_{6}\right) 157.12,147.75,147.62,137.96,135.79,132.02,131.51$, 130.67, 129.66, 126.76, 126.38, 119.91, 101.15, 59.79, 16.43. IR 3400, 3298, 1699. Anal. Calcd for $\mathrm{C}_{20} \mathrm{H}_{19} \mathrm{~N}_{5} \mathrm{O}_{2}$ : C, 66.47; H, 5.30; N, 19.36. Found: C, 66.34; H, 5.63; N, 19.58. ESI-HRMS (m/z) calculated for $[\mathrm{M}+\mathrm{H}]^{+}$362.1612, found 362.1609. 


\section{8-Amino-6-(3,5-di-tert-butyl-4-methoxyphenyl)-2-phenyl-1,2,4-triazolo[4,3-a]pyrazin-3(2H)-}

one (6). Yield 75\%; mp 263-264 ${ }^{\circ} \mathrm{C}$ (2-methoxyethanol). ${ }^{1} \mathrm{H}$ NMR (DMSO-d $\left.\mathrm{d}_{6}\right) 8.08(\mathrm{~d}, 2 \mathrm{H}$, ar, $\mathrm{J}=$ $7.7 \mathrm{~Hz}$ ), 7.78 (s, 2H, ar), $7.68(\mathrm{~s}, 1 \mathrm{H}$, ar), 7.56 (t, 2H, ar, J = $7.7 \mathrm{~Hz}), 7.54$ (br. s, 2H, $\mathrm{NH}_{2}$ ), 7.35 (t, $1 \mathrm{H}$, ar, $\mathrm{J}=7.4 \mathrm{~Hz}), 3.66\left(\mathrm{~s}, 3 \mathrm{H}, \mathrm{CH}_{3}\right), 1.44\left(\mathrm{~s}, 18 \mathrm{H}, 2\left(\mathrm{CH}_{3}\right)_{3}\right) .{ }^{13} \mathrm{C}-\mathrm{NMR}\left(\mathrm{DMSO}_{6} \mathrm{~d}_{6}\right)$ 159.69, $147.65,143.48,137.98,136.56,131.63,131.53,131.21,131.17,129.67,126.77,124.44,119.88$, 64.63, 36.01, 32.42. IR 3474, 3296, 1717. Anal. Calcd for $\mathrm{C}_{26} \mathrm{H}_{31} \mathrm{~N}_{5} \mathrm{O}_{2}: \mathrm{C}, 70.09 ; \mathrm{H}, 7.01 ; \mathrm{N}, 17.72$. Found: C, 69.34; H, 7.16; N, 17.56. ESI-HRMS (m/z) calculated for $[\mathrm{M}+\mathrm{H}]^{+} 446.2551$, found 446.2551.

\section{General procedure for the Synthesis of Hydroxy-substituted 8-Amino-2-phenyl-1,2,4-} triazolo[4,3-a]pyrazin-3(2H)-ones (7-10). $1 \mathrm{M}$ solution of $\mathrm{BBr}_{3}$ in $\mathrm{CH}_{2} \mathrm{Cl}_{2}(6 \mathrm{~mL})$ was slowly added at $0{ }^{\circ} \mathrm{C}$, under nitrogen atmosphere, to a suspension of the methoxy-substituted triazolopyrazines 1-2, 4-5 (1 mmol) in anhydrous $\mathrm{CH}_{2} \mathrm{Cl}_{2}(20 \mathrm{~mL})$. The mixture was stirred at $\mathrm{rt}$ for a different time, depending on the compound structure, then was diluted with water $(10 \mathrm{~mL})$ and neutralized with a $\mathrm{NaHCO}_{3}$ saturated solution. Most of the organic solvent was removed by evaporation at reduced pressure and the obtained solid was collected by filtration. The crude derivatives were dried and purified by recrystallization $(\mathbf{8})$ or by column chromatography $(\mathbf{7}, \mathbf{9}, \mathbf{1 0})$. The 4-hydroxy-2-methoxy- structure of 7 was determined by means of NOESY experiments showing a spatial proximity between the OMe hydrogen atoms and the sole aromatic proton giving a singlet at $6.53 \mathrm{ppm}$.

8-Amino-6-(4-hydroxy-2-methoxyphenyl)-2-phenyl-1,2,4-triazolo[4,3-a]pyrazin-3(2H)-one (7). Reaction time 36 h. Yield 90\%; mp 282-284 ${ }^{\circ} \mathrm{C}$. Purified by column chromatography (eluent cyclohexane 5/EtOAc 5/MeOH 1). ${ }^{1} \mathrm{H}$ NMR (DMSO-d $) 9.67$ (br s, 1H, OH), 8.07 (d, 2H, ar, J = $7.8 \mathrm{~Hz}), 7.91(\mathrm{~d}, 1 \mathrm{H}, \mathrm{ar}, \mathrm{J}=8.6 \mathrm{~Hz}), 7.77(\mathrm{~s}, 1 \mathrm{H}, \mathrm{H}-5), 7.56(\mathrm{t}, 2 \mathrm{H}, \mathrm{ar}, \mathrm{J}=7.7 \mathrm{~Hz}), 7.39-7.33(\mathrm{~m}$, 
$\left.3 \mathrm{H}, 1 \mathrm{ar}+\mathrm{NH}_{2}\right), 6.53\left(\mathrm{~s}, 1 \mathrm{H}\right.$, ar) $, 6.47(\mathrm{~d}, 1 \mathrm{H}$, ar, $\mathrm{J}=8.5 \mathrm{~Hz}), 3.87\left(\mathrm{~s}, 3 \mathrm{H}, \mathrm{CH}_{3}\right)$. Anal. Calcd for $\mathrm{C}_{18} \mathrm{H}_{15} \mathrm{~N}_{5} \mathrm{O}_{3}$ : C, 61.89; H, 4.33; N, 20.05. Found: C, 61.75; H, 4.62; N, 20.17. ESI-HRMS (m/z) calculated for $[\mathrm{M}+\mathrm{H}]^{+} 350.1248$, found 350.1246 .

\section{8-Amino-6-(3,4-dihydroxyphenyl)-2-phenyl-1,2,4-triazolo[4,3-a]pyrazin-3(2H)-one}

Reaction time 4 h. Yield 90\%; mp 256-258 ${ }^{\circ} \mathrm{C}(\mathrm{EtOH}) .{ }^{1} \mathrm{H}$ NMR (DMSO-d 6 ) 9.08 (br s, 1H, OH), 8.98 (br s, 1H, OH), 8.08 (d, 2H, ar, J = 8.0 Hz), 7.55 (t, 2H, ar, J = $7.8 \mathrm{~Hz}), 7.49$ (br s, 2H, $\mathrm{NH}_{2}$ ) 7.44 (s, 1H, ar), 7.35 (s, 1H, ar), 7.35 (t, 1H, ar, J = $7.2 \mathrm{~Hz}), 7.23(\mathrm{~d}, 1 \mathrm{H}$, ar, J = 8.2 Hz), 6.77 (d, 1H, ar, J = 8.2 Hz). ${ }^{13} \mathrm{C}-\mathrm{NMR}\left(\mathrm{DMSO}_{\mathrm{d}}\right)$ 147.59, 147.56, 146.14, 145.66, 137.99, 136.46, 131.51, 129.65, 128.23, 126.71, 119.81, 117.26, 116.06, 113.69, 99.83. IR 3418-3092, 1693, 1682. Anal. Calcd for $\mathrm{C}_{17} \mathrm{H}_{13} \mathrm{~N}_{5} \mathrm{O}_{3}$ : C, 60.89; H, 3.91; N, 20.89. Found: C, 60.72; H, 4.15; N, 20.69. ESI-HRMS $(\mathrm{m} / \mathrm{z})$ calculated for $[\mathrm{M}+\mathrm{H}]^{+}$336.1091, found 336.1092 .

\section{8-Amino-6-(3,4,5-trihydroxyphenyl)-2-phenyl-1,2,4-triazolo[4,3-a]pyrazin-3(2H)-one}

Reaction time 20 h. Yield $79 \%$; mp $281-283{ }^{\circ} \mathrm{C}$. Purified by column chromatography (eluent $\mathrm{CHCl}_{3}$ 9/ MeOH 1). ${ }^{1} \mathrm{H}$ NMR (DMSO-d 6 ) 8.91 (br s, 2H, OH), 8.29 (br s, 1H, OH), 8.07 (d, 2H, ar, J = 7.8 Hz), 7.56 (t, 2H, ar, J = 7.6 Hz), 7.46 (br s, 2H, NH 2$), 7.35$ (t, 1H, ar, J = 7.4 Hz), 7.30 (s, 1H, H-5), 6.85 (s, 2H, ar). Anal. Calcd for $\mathrm{C}_{17} \mathrm{H}_{13} \mathrm{~N}_{5} \mathrm{O}_{4}$ : C, 58.12; H, 3.73; N, 19.93. Found: C, 58.34; H, 3.55; N, 20.13. ESI-HRMS (m/z) calculated for $[\mathrm{M}+\mathrm{H}]^{+}$352.1040, found 352.1039.

\section{8-Amino-6-(4-hydroxy-3,5-dimethylphenyl)-2-phenyl-1,2,4-triazolo[4,3-a]pyrazin-3(2H)-one}

(10). Reaction time $4 \mathrm{~h}$. Yield $90 \%$; mp 236-237 ${ }^{\circ} \mathrm{C}$. Purified by column chromatography (cyclohexane 1/EtOAc 1). ${ }^{1} \mathrm{H}$ NMR (DMSO-d 6 ) 8.40 (br s, 1H, OH), 8.07 (d, 2H, ar, J = $7.9 \mathrm{~Hz}$ ), 7.50 (br s, $\left.2 \mathrm{H}, \mathrm{NH}_{2}\right), 7.55-7.68(\mathrm{~m}, 6 \mathrm{H}, 5 \mathrm{ar}+\mathrm{H}-5), 2.21\left(\mathrm{~s}, 6 \mathrm{H}, 2 \mathrm{CH}_{3}\right) .{ }^{13} \mathrm{C}-\mathrm{NMR}\left(\mathrm{DMSO}-\mathrm{d}_{6}\right)$ $153.94,147.64,147.59,137.99,136.39,131.49,129.65,127.54,126.71,126.04,124.54,119.85$, 99.91, 17.21. IR 3550-3450, 3364, 3323, 1699. Anal. Calcd for $\mathrm{C}_{19} \mathrm{H}_{17} \mathrm{~N}_{5} \mathrm{O}_{2}: \mathrm{C}, 65.69 ; \mathrm{H}, 4.93 ; \mathrm{N}$, 
20.16. Found: C, 65.84; H, 4.68; N, 20.02. ESI-HRMS $(\mathrm{m} / \mathrm{z})$ calculated for $[\mathrm{M}+\mathrm{H}]^{+} 348.1455$, found 348.1457 .

\section{8-Amino-6-(3-tert-butyl-4-hydroxyphenyl)-2-phenyl-1,2,4-triazolo[4,3-a]pyrazin-3(2H)-one}

(11). Aqueous $48 \% \mathrm{HBr}(2.50 \mathrm{~mL})$ was added to a mixture of 8 -amino-6-(3,5-di-tert-butyl-4methoxyphenyl)-2-phenyl-1,2,4-triazolo[4,3-a]pyrazin-3(2H)-one $6(0.5 \mathrm{mmol})$ in glacial acetic acid $(2 \mathrm{~mL})$. The mixture was refluxed for $24 \mathrm{~h}$, then was treated with ice and water $(30 \mathrm{~mL})$. The obtained solid was collected by filtration, rinsed with $\mathrm{Et}_{2} \mathrm{O}$ and petroleum ether, and purified by column chromatography (eluent $\mathrm{CHCl}_{3}$ 9.5/MeOH 0.5). Yield 89\%; mp > $300{ }^{\circ} \mathrm{C}$; ${ }^{1} \mathrm{H}$ NMR (DMSO-d 6$) 9.54(\mathrm{~s}, 1 \mathrm{H}, \mathrm{OH}), 8.08(\mathrm{~d}, 2 \mathrm{H}$, ar, J = $7.7 \mathrm{~Hz}), 7.72(\mathrm{~d}, 1 \mathrm{H}$, ar, J = 2.0 Hz), 7.58-7.54 (m, 3H, 2ar + H-5), $7.50\left(\mathrm{~s}, 3 \mathrm{H}\right.$, ar $\left.+\mathrm{NH}_{2}\right), 7.35(\mathrm{t}, 1 \mathrm{H}$, ar, J = $7.4 \mathrm{~Hz}), 6.82(\mathrm{~d}, 1 \mathrm{H}, \mathrm{ar}, \mathrm{J}=8.3 \mathrm{~Hz})$, $1.40\left(\mathrm{~s}, 9 \mathrm{H},\left(\mathrm{CH}_{3}\right)_{3}\right) .{ }^{13} \mathrm{C}$ NMR $\left(\mathrm{DMSO}_{-} \mathrm{d}_{6}\right) 170.84,147.79,147.61,145.36,144.95,142.94,139.58$, $137.97,135.74,131.56,131.45,129.65,128.73,126.74,126.33,126.02,119.85,119.35,101.01$, 52.50, 45.14, 37.26. IR 3471.87, 3444.87, 1700.10, 1633.71, 1541.12, 1456.26. Anal. Calcd for $\mathrm{C}_{21} \mathrm{H}_{21} \mathrm{~N}_{5} \mathrm{O}_{2}$ : C, 67.18; H, 5.64; N, 18.65. Found: C, 67.34; H, 5.89; N, 18.40. Anal. Calcd for $\mathrm{C}_{21} \mathrm{H}_{21} \mathrm{~N}_{5} \mathrm{O}_{2}$. ESI-HRMS (m/z) calculated for $[\mathrm{M}+\mathrm{H}]^{+}$376.1768, found 376.1765 .

\section{2-(4-(8-Amino-3-oxo-2-phenyl-2,3-dihydro-1,2,4-triazolo[4,3-a]pyrazin-6}

yl)phenoxy)acetonitrile (12). 2-Chloroacetonitrile (6.3 mmol) was added to a suspension of 6-(4hydroxyphenyl)-triazolopyrazine derivative $49^{27}(1.6 \mathrm{mmol})$ and $\mathrm{K}_{2} \mathrm{CO}_{3}(3.1 \mathrm{mmol})$ in anhydrous acetone $(20 \mathrm{~mL})$. The mixture was stirred at $\mathrm{rt}$ for $16 \mathrm{~h}$. The resulting solid was collected by filtration, washed with water $(20 \mathrm{~mL})$ and petroleum ether $(20 \mathrm{~mL})$, and purified by recrystallization. Yield 89\%; mp 249-250 ${ }^{\circ} \mathrm{C}(\mathrm{EtOH}) .{ }^{1} \mathrm{H}$ NMR $\left(\mathrm{DMSO}-\mathrm{d}_{6}\right) 8.08(\mathrm{~d}, 2 \mathrm{H}, \mathrm{ar}, \mathrm{J}=7.7$ 
Hz), $8.00(\mathrm{~d}, 2 \mathrm{H}, \mathrm{ar}, \mathrm{J}=8.8 \mathrm{~Hz}), 7.75(\mathrm{~s}, 1 \mathrm{H}, \mathrm{H}-5), 7.63-7.50\left(\mathrm{~m}, 4 \mathrm{H}, 2 \mathrm{ar}+\mathrm{NH}_{2}\right), 7.36(\mathrm{t}, 1 \mathrm{H}, \mathrm{ar}, \mathrm{J}$ $=7.4 \mathrm{~Hz}), 7.13(\mathrm{~d}, 2 \mathrm{H}, \mathrm{ar}, \mathrm{J}=8.9 \mathrm{~Hz}), 5.22(\mathrm{~s}, 2 \mathrm{H}) .{ }^{13} \mathrm{C}$ NMR $\left(\mathrm{DMSO}_{-} \mathrm{d}_{6}\right) 156.74,147.83,147.63$, $137.97,135.42,131.54,131.23,129.64,127.46,126.74,119.87,117.11,115.28,101.21,54.01$, 40.65, 40.44, 40.23, 40.02, 39.81, 39.60, 39.39. Anal. Calcd for $\mathrm{C}_{19} \mathrm{H}_{14} \mathrm{~N}_{6} \mathrm{O}_{2}: \mathrm{C}, 63.68 ; \mathrm{H}, 3.94 ; \mathrm{N}$, 23.45. Found: C, 63.96; H, 3.72; N, 23.68. ESI-HRMS $(\mathrm{m} / \mathrm{z})$ calculated for $[\mathrm{M}+\mathrm{H}]^{+} 359.1251$, found 359.1252 .

\section{2-(4-(8-Amino-3-oxo-2-phenyl-2,3-dihydro-1,2,4-triazolo[4,3-a]pyrazin-6-}

yl)phenoxy)acetamide (13). The title compound was obtained by reacting the 6-(4hydroxyphenyl)-derivative $4^{27}(1.6 \mathrm{mmol})$ with 2-chloroacetamide $(7.1 \mathrm{mmol})$ in the same experimental condition employed to obtain 12 from 49. Yield 51\%; mp 260-263 ${ }^{\circ} \mathrm{C}(\mathrm{EtOH} / 2$ methoxyethanol). ${ }^{1} \mathrm{H}$ NMR (DMSO-d $\left.{ }_{6}\right) 8.08(\mathrm{~d}, 2 \mathrm{H}$, ar, $\mathrm{J}=7.8 \mathrm{~Hz}), 7.92(\mathrm{~d}, 2 \mathrm{H}$, ar, $\mathrm{J}=8.3 \mathrm{~Hz})$, $7.68(\mathrm{~s}, 1 \mathrm{H}, \mathrm{H}-5), 7.56-7-55\left(\mathrm{~m}, 4 \mathrm{H}, 2 \mathrm{ar}+\mathrm{NH}_{2}\right), 7.41$ (br s, 2H, $\left.\mathrm{NH}_{2}\right), 7.34$ (t, 1H, ar, J = 7.2 Hz), $7.01(\mathrm{~d}, 2 \mathrm{H}$, ar, $\mathrm{J}=8.3 \mathrm{~Hz}), 4.47\left(\mathrm{~s}, 2 \mathrm{H}, \mathrm{CH}_{2}\right) .{ }^{13} \mathrm{C}$ NMR $\left(\mathrm{DMSO}_{6} \mathrm{~d}_{6}\right) 170.32,158.26,147.78$, $147.62,137.98,135.75,131.53,129.88,129.64,127.22,126.74,119.87,115.12,102.92,100.73$, 67.25, 43.05, 40.64, 40.43, 40.22, 40.01, 39.80, 39.59, 39.39. Anal. Calcd for $\mathrm{C}_{19} \mathrm{H}_{16} \mathrm{~N}_{6} \mathrm{O}_{3}: \mathrm{C}$, 60.63; H, 4.28; N, 22.33. Found: C, 60.48; H, 4.41; N, 22.04. ESI-HRMS (m/z) calculated for $[\mathrm{M}+\mathrm{H}]^{+}$377.1357, found 377.1358.

\section{8-Amino-6-(4-(2-aminoethoxy)phenyl)-2-phenyl-1,2,4-triazolo[4,3-a]pyrazin-3(2H)-one}

(14).

The triazolopyrazine $12(0.78 \mathrm{mmol})$ was added portion wise to a suspension of $\mathrm{LiAlH}_{4}(1.95$ mmol) in anhydrous THF $(20 \mathrm{~mL})$ at $0{ }^{\circ} \mathrm{C}$. The mixture was stirred at $\mathrm{rt}$ for $2 \mathrm{~h}$, then it was treated with ice and water $(15 \mathrm{~mL})$ and extracted with EtOAc $(20 \mathrm{~mL}$ x 3). The organic phase was washed with water $(20 \mathrm{~mL} \times 3)$ and anhydrified $\left(\mathrm{Na}_{2} \mathrm{SO}_{4}\right)$. The solvent was eliminated at reduced pressure 
and the resulting solid was collected by filtration, dried and purified by column chromatography (eluent $\mathrm{CHCl}_{3}$ 9.5/ $\mathrm{MeOH}$ 0.5). Yield 78\%; mp 239-241 ${ }^{\circ} \mathrm{C} .{ }^{1} \mathrm{H}$ NMR (DMSO-d $) 8.07$ (d, 2H, ar, J $=7.9 \mathrm{~Hz}), 7.90(\mathrm{~d}, 2 \mathrm{H}, \mathrm{ar}, \mathrm{J}=8.5 \mathrm{~Hz}), 7.65(\mathrm{~s}, 1 \mathrm{H}, \mathrm{H}-5), 7.60-7.45\left(\mathrm{~m}, 4 \mathrm{H}, \mathrm{ar}+\mathrm{NH}_{2}\right), 7.35(\mathrm{t}$, $1 \mathrm{H}, \operatorname{ar}, \mathrm{J}=7.3 \mathrm{~Hz}), 6.98(\mathrm{~d}, 2 \mathrm{H}, \operatorname{ar}, \mathrm{J}=8.5 \mathrm{~Hz}), 3.96\left(\mathrm{t}, 2 \mathrm{H}, \mathrm{CH}_{2}, \mathrm{~J}=5.4 \mathrm{~Hz}\right), 2.89\left(\mathrm{t}, 2 \mathrm{H}, \mathrm{CH}_{2}, \mathrm{~J}=\right.$ $5.3 \mathrm{~Hz}$ ). ${ }^{13} \mathrm{C}-\mathrm{NMR}\left(\mathrm{DMSO}_{-} \mathrm{d}_{6}\right)$ 159.22, 147.76, 147.62, 137.99, 135.88, 131.53, 129.66, 129.20, 127.29, 126.75, 119.87, 114.87, 100.52, 70.66, 41.42. IR 3391, 3329, 3215, 1705, 1655. Anal. Calcd for $\mathrm{C}_{19} \mathrm{H}_{18} \mathrm{~N}_{6} \mathrm{O}_{2}$ : C, 62.97; H, 5.01; N, 23.19. Found: C, 62.74; H, 4.85; N, 23.02. ESI-HRMS $(\mathrm{m} / \mathrm{z})$ calculated for $[\mathrm{M}+\mathrm{H}]^{+}$363.1564, found 363.1564 .

\section{N-(2-(4-(8-Amino-3-oxo-2-phenyl-2,3-dihydro-1,2,4-triazolo[4,3-a]pyrazin-6-}

yl)phenoxy)ethyl)-5-(1,2-dithiolan-3-yl)pentanamide (15). A mixture of the 6-(4-(2aminoethoxy)phenyl)-derivative 14 (0.66 mmol), (R,S) lipoic acid (0.73 mmol), 1-(3(dimethylamino)-propyl))-3-ethylcarbodiimide hydrochloride $(0.76 \mathrm{mmol})$, triethylamine (1.12 mmol) and 1-hydroxybenzotriazole $(0.76 \mathrm{mmol})$, in anhydrous DMF $(1.5 \mathrm{~mL})$, was stirred for about $2 \mathrm{~h}$ at $\mathrm{rt}$. The mixture was diluted with water $(20 \mathrm{~mL})$ and the obtained solid was collected by filtration, rinsed with water $(3 \mathrm{~mL}), \mathrm{Et}_{2} \mathrm{O}(10 \mathrm{~mL})$, dried and purified by column chromatography (eluent cyclohexane 2/EtOAc 8) and then recrystallized. Yield 82\%; mp 202-204 ${ }^{\circ} \mathrm{C}$ (nitromethane). ${ }^{1} \mathrm{H}$ NMR $\left(\mathrm{DMSO}_{-} \mathrm{d}_{6}\right)$ 8.09-8.06 (m, 3H, 2ar $\left.+\mathrm{NH}\right), 7.91(\mathrm{~d}, 2 \mathrm{H}$, ar, $\mathrm{J}=8.1 \mathrm{~Hz})$, 7.66 (s, 1H, H-5), 7.63-7.49 (m, 4H, 2ar $\left.+\mathrm{NH}_{2}\right), 7.36(\mathrm{t}, 1 \mathrm{H}, \mathrm{ar}, \mathrm{J}=7.3 \mathrm{~Hz}), 6.99(\mathrm{~d}, 2 \mathrm{H}, \mathrm{ar}, \mathrm{J}=8.2$ $\mathrm{Hz}), 4.02\left(\mathrm{~d}, 2 \mathrm{H}, \mathrm{CH}_{2}-\mathrm{O}, \mathrm{J}=5.0 \mathrm{~Hz}\right), 3.64-3.53(\mathrm{~m}, 1 \mathrm{H}, \mathrm{CH}), 3.46-3.43(\mathrm{~m}, 2 \mathrm{H}, 2 \mathrm{CH}), 3.21-3.02$ (m, 2H, 2CH), 2.38-2.30 (m, 1H, CH), 2.11-2.03 (m, 2H, $\left.\mathrm{CH}_{2}\right), 1.90-1.75(\mathrm{~m}, 1 \mathrm{H}, \mathrm{CH}), 1.65-1.60$ (m, 1H, CH), 1.56-1.48 (m, 3H, $\left.\mathrm{CH}_{2}+\mathrm{CH}\right), 1.35-1.31\left(\mathrm{~m}, 2 \mathrm{H}, \mathrm{CH}_{2}\right) .{ }^{13} \mathrm{C}$ NMR $\left(\mathrm{DMSO}-\mathrm{d}_{6}\right)$ 172.80, $158.97,147.77,147.62,137.99,135.82,131.53,129.66,129.40,127.30,126.75,119.87,114.90$, $66.89,56.59,38.68,38.55,35.56,34.57,28.72,25.47$. IR 3358, 3285, 1709, 1628. Anal. Calcd for $\mathrm{C}_{27} \mathrm{H}_{30} \mathrm{~N}_{6} \mathrm{O}_{3} \mathrm{~S}_{2}$ : C, 58.89; H, 5.49; N, 15.26. Found: C, 58.65; H, 5.78; N, 15.04. ESI-HRMS (m/z) calculated for $[\mathrm{M}+\mathrm{H}]^{+}$551.1894, found 551.1897. 


\section{N-(2-(4-(8-amino-3-oxo-2-phenyl-2,3-dihydro-1,2,4-triazolo[4,3-a]pyrazin-6-} yl)phenoxy)ethyl)-3,5-di-tert-butyl-4-hydroxybenzamide (16). The title compound was synthesized by reacting the 6-(4-(2-aminoethoxy)phenyl) derivative $14(0.66 \mathrm{mmol})$ and 3,5-di-tertbutyl-4-hydroxybenzoic acid $(0.73 \mathrm{mmol})$ in the same experimental conditions described above to prepare compound $\mathbf{1 7}$ from 16. The crude compound was purified by column chromatography (eluent cyclohexane 4/ EtOAc 6). Yield 78\%; mp 259-260 ${ }^{\circ} \mathrm{C} .{ }^{1} \mathrm{H}$ NMR $\left(\right.$ DMSO-d $\left._{6}\right) 8.51(\mathrm{t}, 1 \mathrm{H}$, $\mathrm{NH}, \mathrm{J}=5.5 \mathrm{~Hz}), 8.08(\mathrm{~d}, 2 \mathrm{H}$, ar, $\mathrm{J}=7.9 \mathrm{~Hz}), 7.91(\mathrm{~d}, 2 \mathrm{H}, \mathrm{ar}, \mathrm{J}=8.7 \mathrm{~Hz}), 7.66(\mathrm{~s}, 1 \mathrm{H}, \mathrm{H}-5), 7.63(\mathrm{~s}$, 2H, ar), 7.59-7.54 (m, 4H, 2ar + $\left.\mathrm{NH}_{2}\right), 7.39(\mathrm{~s}, 1 \mathrm{H}, \mathrm{OH}), 7.36(\mathrm{t}, 1 \mathrm{H}, \mathrm{ar}, \mathrm{J}=7.4 \mathrm{~Hz}), 7.02(\mathrm{~d}, 2 \mathrm{H}$, ar, $\mathrm{J}=8.8 \mathrm{~Hz}), 4.15\left(\mathrm{t}, 2 \mathrm{H}, \mathrm{CH}_{2}, \mathrm{~J}=5.8 \mathrm{~Hz}\right), 3.62\left(\mathrm{~d}, 2 \mathrm{H}, \mathrm{CH}_{2}, \mathrm{~J}=5.6 \mathrm{~Hz}\right), 1.41\left(\mathrm{~s}, 18 \mathrm{H}, 2\left(\mathrm{CH}_{3}\right)_{3}\right)$. ${ }^{13} \mathrm{C}$ NMR (DMSO-d $)$ 167.75, 158.99, 157.14, 147.77, 147.61, 144.69, 138.69, 137.98, 137.34, $135.84,131.53,129.64,129.39,127.33,126.75,125.97,124.54,119.87,114.90,66.69,35.05$, 30.68. IR 3315, 3213, 1699, 1616, $14561377,1315,1248,1178$. Anal. Calcd for $\mathrm{C}_{34} \mathrm{H}_{38} \mathrm{~N}_{6} \mathrm{O}_{4}$ : C, 68.67; H, 6.44; N, 14.13. Found: C, 68.88; H, 6.67; N, 14.35. ESI-HRMS (m/z) calculated for $[\mathrm{M}+\mathrm{H}]^{+}$595.3027, found 595.3028.

\section{N-(4-(8-amino-3-oxo-2-phenyl-2,3-dihydro-1,2,4-triazolo[4,3-a]pyrazin-6-yl)phenyl)-5-(1,2-}

dithiolan-3-yl)pentanamide (17). The title compound was obtained by reacting the 6-(4aminophenyl) derivative $\mathbf{5 0}^{33}(1.00 \mathrm{mmol})$ with $(\mathrm{R}, \mathrm{S})$ lipoic acid $(1.35 \mathrm{mmol})$ in the same experimental conditions described above to synthesize 15 from 14. The crude compound was purified by recrystallization. Yield $95 \%$; mp $229-233{ }^{\circ} \mathrm{C}$ (nitromethane). ${ }^{1} \mathrm{H}-\mathrm{NMR}$ (DMSO- $\mathrm{d}_{6}$ ) 9.96 (br s, 1H, NH), 8.08 (d, 2H, ar, J = $7.9 \mathrm{~Hz}), 7.91(\mathrm{~d}, 2 \mathrm{H}$, ar, J = 8.7 Hz), 7.69 (s, 1H, H-5) , 7.65 (d, $2 \mathrm{H}$, ar, $\mathrm{J}=8.7 \mathrm{~Hz}), 7.58-7.64\left(\mathrm{~m}, 4 \mathrm{H}, \mathrm{ar}+\mathrm{NH}_{2}\right), 7.35(\mathrm{t}, 1 \mathrm{H}$, ar, $\mathrm{J}=7.4 \mathrm{~Hz}), 3.64-3.66(\mathrm{~m}, 1 \mathrm{H}$, $\mathrm{CH}), 3.19-3.14(\mathrm{~m}, 2 \mathrm{H}, 2 \mathrm{CH}), 2.43-2.44(\mathrm{~m}, 1 \mathrm{H}, \mathrm{CH}), 2.28-2.32\left(\mathrm{~m}, 2 \mathrm{H}, \mathrm{CH}_{2}\right), 1.88-1.85(\mathrm{~m}, 1 \mathrm{H}$, $\mathrm{CH}), 1.73-1.55\left(\mathrm{~m}, 4 \mathrm{H}, 2 \mathrm{CH}_{2}\right), 1.43-1.36\left(\mathrm{~m}, 2 \mathrm{H}, \mathrm{CH}_{2}\right) .{ }^{13} \mathrm{C}-\mathrm{NMR}\left(\mathrm{DMSO}_{6} \mathrm{~d}_{6}\right)$ 171.60; 147.79; 
$147.61 ; 139.68 ; 137.98 ; 135.75 ; 131.56 ; 131.39 ; 129.67 ; 126.75 ; 126.31 ; 120.00 ; 119.30 ; 100.98 ;$ $56.58 ; 38.58 ; 36.74 ; 34.64 ; 28.82 ; 25.35$. IR 3431, 3312, 3208, 1694, 1682. Anal. Calcd for $\mathrm{C}_{25} \mathrm{H}_{26} \mathrm{~N}_{6} \mathrm{O}_{2} \mathrm{~S}_{2}$ : C, 59.27; H, 5.17; N, 16.59. Found: C, 59.04; H, 5.36; N, 16.42. ESI-HRMS (m/z) calculated for $[\mathrm{M}+\mathrm{H}]^{+}$507.1631, found 507.1628.

\section{N-(4-(8-Amino-3-oxo-2-phenyl-2,3-dihydro-1,2,4-triazolo[4,3-a]pyrazin-6-}

yl)phenyl)acrylamide (18). A mixture of the 6-(4-aminophenyl)-derivative $\mathbf{5 0}^{33}$ (1.0 mmol), 3chloropropionic acid (1.2 $\mathrm{mmol}), \quad$ 1-(3-(dimethylamino)-propyl))-3-ethylcarbodiimide hydrochloride $(0.76 \mathrm{mmol})$ and triethylamine $(1.12 \mathrm{mmol})$, in anhydrous DMF $(1.5 \mathrm{~mL})$ was stirred for about $2 \mathrm{~h}$ at $\mathrm{rt}$. The suspension was diluted with water $(20 \mathrm{~mL})$ and the obtained solid was collected by filtration, rinsed with water $(3 \mathrm{~mL}), \mathrm{Et}_{2} \mathrm{O}(10 \mathrm{~mL})$, dried and purified by recrystallization. Yield 92\%; mp $>300{ }^{\circ} \mathrm{C}$ (nitromethane). ${ }^{1} \mathrm{H}-\mathrm{NMR}\left(\mathrm{DMSO}-\mathrm{d}_{6}\right) 10.33$ (br s, $1 \mathrm{H}$, NH), $8.07(\mathrm{~d}, 2 \mathrm{H}$, ar, J = 7.9 Hz), $7.93(\mathrm{~d}, 2 \mathrm{H}$, ar, J = 8.9 Hz), 7.75 (d, 2H, ar, J = 8.5 Hz), 7.69 (s, 1H, H-5), 7.54-7.52 (m, 4H, $\left.2 \mathrm{ar}+\mathrm{NH}_{2}\right) 7.33(\mathrm{t}, 1 \mathrm{H}, \mathrm{ar}, \mathrm{J}=7.2 \mathrm{~Hz}), 6.47(\mathrm{dd}, 1 \mathrm{H}, \mathrm{CH}, \mathrm{J}=16.9$, $10.0 \mathrm{~Hz}), 6.28(\mathrm{~d}, 1 \mathrm{H}, \mathrm{CH}, \mathrm{J}=16.9 \mathrm{~Hz}), 5.77(\mathrm{~d}, 1 \mathrm{H}, \mathrm{CH}, \mathrm{J}=10.0 \mathrm{~Hz}) .{ }^{13} \mathrm{C}-\mathrm{NMR}\left(\mathrm{DMSO}-\mathrm{d}_{6}\right)$ $163.63,147.79,147.59,139.40,137.96,135.70,132.36,131.91,131.54,129.60,127.28,126.69$, 126.37, 119.82, 119.65, 101.15. IR 3376, 3331, 3296, 3206, 3181, 1694, 1681.93, 1643, 1634. Anal. Calcd for $\mathrm{C}_{20} \mathrm{H}_{16} \mathrm{~N}_{6} \mathrm{O}_{2}:$ C, 64.51; H, 4.33; N, 22.57. Found: C, 64.42; H, 4.54; N, 22.72. ESIHRMS (m/z) calculated for $[\mathrm{M}+\mathrm{H}]^{+}$373.1408, found 373.1403.

\section{3-Amino-N-(4-(8-amino-3-oxo-2-phenyl-2,3-dihydro-1,2,4-triazolo[4,3-a]pyrazin-6-}

yl)phenyl)propanamide (19). A suspension of the acrylamido derivative $18(0.13 \mathrm{mmol})$ in ethanol saturated solution with $\mathrm{NH}_{3}(15 \mathrm{~mL})$ was heated at $130{ }^{\circ} \mathrm{C}$ in a sealed tube for $3 \mathrm{~h}$. The mixture was cooled at rt and the solid was collected by filtration, washed with water (about 5-10 mL), dried and 
purified by column chromatography (eluent $\mathrm{CH}_{2} \mathrm{Cl}_{2}$ 8/MeOH 2/ 33\% $\mathrm{NH}_{3}$ aqueous solution 0.2). Yield 89\%; mp 239-241 ${ }^{\circ} \mathrm{C} .{ }^{1} \mathrm{H}-\mathrm{NMR}\left(\mathrm{DMSO}_{-} \mathrm{d}_{6}\right) 10.18$ (br s, $\left.1 \mathrm{H}, \mathrm{NH}\right), 8.08$ (d, 2H, ar, J = 7.9 $\mathrm{Hz}), 7.91(\mathrm{~d}, 2 \mathrm{H}, \mathrm{ar}, \mathrm{J}=8.7 \mathrm{~Hz}), 7.69-7.65(\mathrm{~m}, 3 \mathrm{H}, 2 \mathrm{ar}+\mathrm{H}-5), 7.58-7.54\left(\mathrm{~m}, 4 \mathrm{H}, 2 \mathrm{ar}+\mathrm{NH}_{2}, \mathrm{~J}=\right.$ $7.8 \mathrm{~Hz}), 7.35(\mathrm{t}, 1 \mathrm{H}$, ar, $\mathrm{J}=7.4 \mathrm{~Hz}), 2.87\left(\mathrm{t}, 2 \mathrm{H}, \mathrm{CH}_{2}, \mathrm{~J}=6.2 \mathrm{~Hz}\right), 2.43\left(\mathrm{t}, 2 \mathrm{H}, \mathrm{CH}_{2}, \mathrm{~J}=6.4 \mathrm{~Hz}\right)$. ${ }^{13}$ C-NMR (DMSO-d $)$ 170.98, 147.79, 147.61, 139.63, 137.98, 135.76, 131.56, 131.40, 129.65, 126.74, 126.31, 119.85, 119.33, 100.98, 39.37, 38.45. Anal. Calcd for $\mathrm{C}_{20} \mathrm{H}_{19} \mathrm{~N}_{7} \mathrm{O}_{2}$ : C, 61.69; $\mathrm{H}$, 4.92; N, 25.18. Found: C, 61.45; H, 4.85; N, 25.36. ESI-HRMS $(\mathrm{m} / \mathrm{z})$ calculated for $[\mathrm{M}+\mathrm{H}]^{+}$ 390.1673 , found 390.1673 .

\section{N-(3-((4-(8-amino-3-oxo-2-phenyl-2,3-dihydro-1,2,4-triazolo[4,3-a]pyrazin-6-}

yl)phenyl)amino)-3-oxopropyl)-5-(1,2-dithiolan-3-yl)pentanamide (20). The title compound 20 was synthesized by reacting compound $19(1.0 \mathrm{mmol})$ and $(\mathrm{R}, \mathrm{S})$ lipoic acid $(1.1 \mathrm{mmol})$ in the same experimental conditions described above to prepare compound $\mathbf{1 5}$ from 14. The crude derivative was purified by column chromatography $\left(\mathrm{CH}_{2} \mathrm{Cl}_{2}\right.$ 9.7/MeOH 0.3) and then recrystallized. Yield 65\%; mp 250-251 ${ }^{\circ} \mathrm{C}$ (nitromethane). ${ }^{1} \mathrm{H}$ NMR (DMSO-d $\left.{ }_{6}\right) 10.03$ (br s, $\left.1 \mathrm{H}, \mathrm{NH}\right), 8.08$ (d, 2H, ar, J $=7.9 \mathrm{~Hz}), 7.92(\mathrm{~m}, 3 \mathrm{H}, 2 \mathrm{ar}+\mathrm{NH}), 7.69-7.65(\mathrm{~m}, 3 \mathrm{H}, 2 \mathrm{ar}+\mathrm{H}-5), 7.58-7.54\left(\mathrm{~m}, 4 \mathrm{H}, 2 \mathrm{ar}+\mathrm{NH}_{2}\right)$, $7.35(\mathrm{t}, 1 \mathrm{H}$, ar, $\mathrm{J}=7.4 \mathrm{~Hz}), 3.59-3.52(\mathrm{~m}, 1 \mathrm{H}, \mathrm{CH}), 3.45-3.41\left(\mathrm{~m}, 2 \mathrm{H}, \mathrm{CH}_{2}\right), 3.19-3.12(\mathrm{~m}, 1 \mathrm{H}$, $\mathrm{CH}), 3.11-3.04(\mathrm{~m}, 1 \mathrm{H}, \mathrm{CH}), 2.58-2.54\left(\mathrm{~m}, 2 \mathrm{H}, \mathrm{CH}_{2}\right), 2.31-2.36(\mathrm{~m}, 1 \mathrm{H}, \mathrm{CH}), 2.07(\mathrm{t}, 2 \mathrm{H}, \mathrm{J}=7.2$ $\mathrm{Hz}), 1.89-1.83(\mathrm{~m}, 1 \mathrm{H}, \mathrm{CH}), 1.66-1.59(\mathrm{~m}, 1 \mathrm{H}), 1.54-1.47(\mathrm{~m}, 3 \mathrm{H}), 1.36-1.29(\mathrm{~m}, 2 \mathrm{H}) .{ }^{13} \mathrm{C}-\mathrm{NMR}$ (DMSO-d $)_{6}$ 172.57, 170.00, 147.79, 147.62, 139.59, 137.98, 135.75, 131.56, 131.49, 129.66, $126.76,126.30,119.87,119.36,101.01,56.57,38.54,36.97,35.60,35.50,34.59,28.71,25.56$. Anal. Calcd for $\mathrm{C}_{28} \mathrm{H}_{31} \mathrm{~N}_{7} \mathrm{O}_{2} \mathrm{~S}_{2}$ : C, 58.21; H, 5.41; N, 16.97. Found: C, 57.96; H, 5.53; N, 16.68. ESI-HRMS (m/z) calculated for $[\mathrm{M}+\mathrm{H}]^{+}$578.2003, found 578.2007. 


\section{N-(3-((4-(8-amino-3-oxo-2-phenyl-2,3-dihydro-1,2,4-triazolo[4,3-a]pyrazin-6-}

yl)phenyl)amino)-3-oxopropyl)-3,5-di-tert-butyl-4-hydroxybenzamide (21). The title compound was synthesized by reacting compound $20(1.0 \mathrm{mmol})$ and 3,5-di-tert-butyl-4-hydroxybenzoic acid $(0.73 \mathrm{mmol})$ in the same experimental conditions described above to prepare compound $\mathbf{1 5}$ from $\mathbf{1 4}$. Yield 90\%; mp $>300{ }^{\circ} \mathrm{C}$ (nitromethane). ${ }^{1} \mathrm{H}$ NMR $\left(\right.$ DMSO-d $\left._{6}\right) 10.05(\mathrm{~s}, 1 \mathrm{H}, \mathrm{NH}), 8.42(\mathrm{t}, 1 \mathrm{H}, \mathrm{J}=$ $5.5 \mathrm{~Hz}), 8.08(\mathrm{~d}, 2 \mathrm{H}$, ar, J = 7.9 Hz), $7.91(\mathrm{~d}, 2 \mathrm{H}$, ar, J = 8.6 Hz), $7.69-7.65(\mathrm{~m}, 3 \mathrm{H}, 2 \mathrm{ar},+\mathrm{H}-5)$, 7.60-7.54 (m, 6H, 4ar $\left.+\mathrm{NH}_{2}\right), 7.42-7.30(\mathrm{~m}, 2 \mathrm{H}, 1 \mathrm{ar}+\mathrm{OH}), 3.53\left(\mathrm{dd}, 2 \mathrm{H}, \mathrm{CH}_{2}, \mathrm{~J}=12.4,6.4 \mathrm{~Hz}\right)$, $2.63\left(\mathrm{t}, 2 \mathrm{H}, \mathrm{CH}_{2}, \mathrm{~J}=6.8 \mathrm{~Hz}\right), 1.39\left(\mathrm{~s}, 18 \mathrm{H}, 2\left(\mathrm{CH}_{3}\right)_{3}\right) .{ }^{13} \mathrm{C} \mathrm{NMR}\left(\mathrm{DMSO}-\mathrm{d}_{6}\right)$ 170.19, 167.64, 157.02, $147.80,147.62,139.58,138.66,137.99,135.77,131.57,131.52,129.64,126.75,126.29,124.47$, 119.88, 119.45, 101.02, 37.19, 36.38, 35.03, 30.68. Anal. Calcd for $\mathrm{C}_{35} \mathrm{H}_{39} \mathrm{~N}_{7} \mathrm{O}_{4}$ : C, 67.61; $\mathrm{H}, 6.32$; N, 15.77. Found: C, 67.75; H, 6.58; N, 15.89. ESI-HRMS (m/z) calculated for $[\mathrm{M}+\mathrm{H}]^{+} 622.3136$, found 622.3127

General Procedure for the Synthesis of 2-Bromo-1-arylethanones 27 and 28. A solution of bromine $(5.66 \mathrm{mmol})$ in $\mathrm{CHCl}_{3}(5 \mathrm{ml})$ was added dropwise to a solution of the commercial 1-(3,5dimethyl-4-methoxyphenyl)ethanone $29(5.7 \mathrm{mmol})$ or suitably prepared 1-(3,5-ditert-butyl-4methoxyphenyl)ethanone $30(5.7 \mathrm{mmol})$ in $\mathrm{Et}_{2} \mathrm{O}(10 \mathrm{ml})$ and $\mathrm{CHCl}_{3}(5 \mathrm{ml})$, maintaining the temperature at $0{ }^{\circ} \mathrm{C}$. After the addition was completed, the mixture was stirred at $\mathrm{rt}$ for $2 \mathrm{~h}$, then it was diluted with $\mathrm{CHCl}_{3}$ (about $\left.5 \mathrm{ml}\right)$. The solution was washed with brine $(20 \mathrm{~mL})$ and water $(20$ $\mathrm{mL} \times 3)$. The anhydrous $\left(\mathrm{Na}_{2} \mathrm{SO}_{4}\right)$ organic phase was evaporated at reduced pressure to give an oily residue which was used directly in the next step.

2-Bromo-1-(3,5-dimethyl-4-methoxyphenyl)ethanone (27). Yield 75\%. ${ }^{1} \mathrm{H} \mathrm{NMR}\left(\mathrm{CDCl}_{3}\right) 7.69$ (s, $2 \mathrm{H}$, ar), $4.43\left(\mathrm{~s}, 2 \mathrm{H}, \mathrm{CH}_{2}\right), 3.80\left(\mathrm{~s}, 3 \mathrm{H}, \mathrm{CH}_{3}\right), 2.36\left(\mathrm{~s}, 6 \mathrm{H}, 2 \mathrm{CH}_{3}\right)$. 


\section{2-Bromo-1-(3,5-di-tert-butyl-4-methoxyphenyl)ethanone (28). Yield 96\%. ${ }^{1} \mathrm{H} \mathrm{NMR}\left(\mathrm{CDCl}_{3}\right)$ $7.94\left(\mathrm{~s}, 2 \mathrm{H}\right.$, ar), $4.43\left(\mathrm{~s}, 2 \mathrm{H}, \mathrm{CH}_{2}\right), 3.75\left(\mathrm{~s}, 3 \mathrm{H}, \mathrm{CH}_{3}\right), 1.47\left(\mathrm{~s}, 18 \mathrm{H}, 2\left(\mathrm{CH}_{3}\right)_{3}\right)$.}

\section{1-(3,5-Di-tert-butyl-4-methoxyphenyl)ethanone (30)}

A suspension of 1-(3,5-di-tert-butyl-4-hydroxyphenyl)ethanone ${ }^{49}$ (9.3 mmol), $\mathrm{CH}_{3} \mathrm{I}$ (46.3 mmol) and potassium carbonate $(13.9 \mathrm{mmol})$ in 2-butanone $(25 \mathrm{~mL})$ was refluxed for about $72 \mathrm{~h}$ under nitrogen atmosphere. During this time, other five portions of $\mathrm{CH}_{3} \mathrm{I}$ (each of $46.3 \mathrm{mmol}$ ) were added. After the reaction was completed, the obtained solid was filtered off and the mother solution was evaporated at reduced pressure. The residue was taken up with $\mathrm{Et}_{2} \mathrm{O}(20 \mathrm{~mL})$ and the solid obtained was filtered off. The solvent was evaporated at reduced pressure to give an orange semisolid residue which was pure enough (TLC, NMR) to be used for the next step without further purification. Yield 95\%. ${ }^{1} \mathrm{H} \mathrm{NMR}\left(\mathrm{CDCl}_{3}\right) 7.90(\mathrm{~s}, 2 \mathrm{H}, \mathrm{ar}), 3.74\left(\mathrm{~s}, 3 \mathrm{H}, \mathrm{CH}_{3}\right), 2.59\left(\mathrm{~s}, 3 \mathrm{H}, \mathrm{CH}_{3}\right), 1.47(\mathrm{~s}, 18 \mathrm{H}$, $\left.2\left(\mathrm{CH}_{3}\right)_{3}\right)$.

General Procedure for the Synthesis of Ethyl 1-phenyl-5-oxo-4-(2-aryl-2-oxoethyl)-4,5dihydro-1H-1,2,4-triazole-3-carboxylates 31-36. The suitable $\alpha$-bromoketone $23-26^{45-48}$ or 27 and 28 (1.2 mmol) was added to a mixture of ethyl 1-phenyl-5-oxo-1,2,4-triazole-3-carboxylate $\mathbf{2 2}^{44}(1$ $\mathrm{mmol})$ and potassium carbonate $(2 \mathrm{mmol})$ in $\mathrm{DMF} / \mathrm{CH}_{3} \mathrm{CN}(1: 9,10 \mathrm{~mL})$. The suspension was stirred at $\mathrm{rt}$ until the disappearance of the starting material (TLC monitoring, 2-24 h). The solvent was removed at reduced pressure and the residue was treated with water $(50-70 \mathrm{~mL})$. The resulting precipitate was collected by filtration, washed with water $(30 \mathrm{~mL}), \mathrm{Et}_{2} \mathrm{O}(20 \mathrm{~mL})$ and then recrystallized. Compound $\mathbf{3 1}$ was purified by column chromatography.

Ethyl 4-[2-(2,4-dimethoxyphenyl)-2-oxoethyl]-5-oxo-1-phenyl-4,5-dihydro-1H-1,2,4-triazole-3carboxylate (31). Yield $85 \%$; mp $150-152{ }^{\circ} \mathrm{C}$. Purified by column chromatography (eluent 
cyclohexane 6/ EtOAc 4). ${ }^{1} \mathrm{H}$ NMR $\left(\mathrm{CDCl}_{3}\right)$ 7.99-8.07 (m, 3H, ar), 7.47 (t, 2H, ar, J = 7.8 Hz), 7.30 $(\mathrm{t}, 1 \mathrm{H}, \operatorname{ar}, \mathrm{J}=7.3 \mathrm{~Hz}), 6.61(\mathrm{dd}, 1 \mathrm{H}, \mathrm{ar}, \mathrm{J}=1.9 \mathrm{~Hz}, \mathrm{~J}=6.8 \mathrm{~Hz}) 6.53(\mathrm{~d}, 1 \mathrm{H}, \operatorname{ar}, \mathrm{J}=1.8 \mathrm{~Hz}), 5.45(\mathrm{~s}$, 2H, $\left.\mathrm{CH}_{2}\right), 4.41\left(\mathrm{q}, 2 \mathrm{H}, \mathrm{CH}_{2}, \mathrm{~J}=7.1 \mathrm{~Hz}\right), 3.98\left(\mathrm{~s}, 3 \mathrm{H}, \mathrm{CH}_{3}\right), 3.96\left(\mathrm{~s}, 3 \mathrm{H}, \mathrm{CH}_{3}\right), 1.38\left(\mathrm{t}, 3 \mathrm{H}, \mathrm{CH}_{3}, \mathrm{~J}=\right.$ 7.1 Hz). Anal. Calcd for $\mathrm{C}_{21} \mathrm{H}_{21} \mathrm{~N}_{3} \mathrm{O}_{6}$ : C, 61.31; H, 5.14; N, 10.21. Found: C, 61.20; H, 5.29; N, 10.34.

Ethyl 4-(2-(3,4-dimethoxyphenyl)-2-oxoethyl)-5-oxo-1-phenyl-4,5-dihydro-1H-1,2,4-triazole-3carboxylate (32). Yield 80\%; mp 159-161 ${ }^{\circ} \mathrm{C}(\mathrm{EtOH}) .{ }^{1} \mathrm{H}-\mathrm{NMR}\left(\mathrm{CDCl}_{3}\right) 8.04(\mathrm{~d}, 2 \mathrm{H}$, ar, $\mathrm{J}=7.92$ Hz), $7.69(\mathrm{~d}, 1 \mathrm{H}, \mathrm{ar}, \mathrm{J}=8.4 \mathrm{~Hz}), 7.55(\mathrm{~s}, 1 \mathrm{H}, \mathrm{ar}), 7.48(\mathrm{t}, 2 \mathrm{H}, \mathrm{ar}, \mathrm{J}=7.6 \mathrm{~Hz}), 7.32(\mathrm{t}, 1 \mathrm{H}, \mathrm{ar}, \mathrm{J}=7.4$ $\mathrm{Hz}), 6.98(\mathrm{~d}, 1 \mathrm{H}, \mathrm{ar}, \mathrm{J}=8.4 \mathrm{~Hz}), 5.55\left(\mathrm{~s}, 2 \mathrm{H}, \mathrm{CH}_{2}\right), 4.41\left(\mathrm{q}, 2 \mathrm{H}, \mathrm{CH}_{2}, \mathrm{~J}=7.1 \mathrm{~Hz}\right), 4.01(\mathrm{~s}, 3 \mathrm{H}$, $\left.\mathrm{CH}_{3}\right), 3.97\left(\mathrm{~s}, 3 \mathrm{H}, \mathrm{CH}_{3}\right), 1.41\left(\mathrm{t}, 3 \mathrm{H}, \mathrm{CH}_{3}, \mathrm{~J}=7.1 \mathrm{~Hz}\right)$. Anal. Calcd for $\mathrm{C}_{21} \mathrm{H}_{21} \mathrm{~N}_{3} \mathrm{O}_{6}: \mathrm{C}, 61.31 ; \mathrm{H}$, 5.14; N, 10.21. Found: C, 61.04; H, 5.36; N, 10.03 .

Ethyl 4-[2-(3,4-methylendioxyphenyl)-2-oxoethyl]-5-oxo-1-phenyl-4,5-dihydro-1H-1,2,4triazole-3-carboxylate (33). Yield 77\%; mp 179-181 ${ }^{\circ} \mathrm{C}$ (cyclohexane/EtOAc). ${ }^{1} \mathrm{H}$ NMR $\left(\mathrm{CDCl}_{3}\right)$ $8.03(\mathrm{~d}, 2 \mathrm{H}$, ar, J = 8.0 Hz), $7.65(\mathrm{~d}, 1 \mathrm{H}$, ar, $\mathrm{J}=8.2 \mathrm{~Hz}), 7.48(\mathrm{t}, 3 \mathrm{H}$, ar, J = 8.0 Hz), $7.31(\mathrm{t}, 1 \mathrm{H}$, ar, J $=7.6 \mathrm{~Hz}), 6.94(\mathrm{~d}, 1 \mathrm{H}, \mathrm{ar}, \mathrm{J}=8.2 \mathrm{~Hz}), 6.11\left(\mathrm{~s}, 2 \mathrm{H}, \mathrm{CH}_{2}\right), 5.50\left(\mathrm{~s}, 2 \mathrm{H}, \mathrm{CH}_{2}\right), 4.42\left(\mathrm{q}, 2 \mathrm{H}, \mathrm{CH}_{2}, \mathrm{~J}=\right.$ $7.1 \mathrm{~Hz}$ ), 1.39 (t, 3H, $\mathrm{CH}_{3}, \mathrm{~J}=7.1 \mathrm{~Hz}$ ). Anal. Calcd for $\mathrm{C}_{20} \mathrm{H}_{17} \mathrm{~N}_{3} \mathrm{O}_{6}: \mathrm{C}, 60.76 ; \mathrm{H}, 4.33 ; \mathrm{N}, 10.63$. Found: C, 60.58; H, 4.48; N, 10.58 .

Ethyl 4-[2-(3,4,5-trimethoxyphenyl)-2-oxoethyl]-5-oxo-1-phenyl-4,5-dihydro-1H-1,2,4triazole-3-carboxylate (34). Yield 95\%; mp 131-133 ${ }^{\circ} \mathrm{C}$ (cyclohexane/EtOAc). ${ }^{1} \mathrm{H}$ NMR $\left(\mathrm{CDCl}_{3}\right)$ $8.04(\mathrm{~d}, 2 \mathrm{H}$, ar, $\mathrm{J}=8.6 \mathrm{~Hz}), 7.49(\mathrm{t}, 2 \mathrm{H}$, ar, $\mathrm{J}=7.4 \mathrm{~Hz}), 7.27-7.34\left(\mathrm{~m}, 3 \mathrm{H}\right.$, ar), $5.55\left(\mathrm{~s}, 2 \mathrm{H}, \mathrm{CH}_{2}\right)$, 
3.96 (br s, $\left.9 \mathrm{H}, 3 \mathrm{CH}_{3}\right), 4.43\left(\mathrm{q}, 2 \mathrm{H}, \mathrm{CH}_{2}, \mathrm{~J}=7.1 \mathrm{~Hz}\right), 1.41\left(\mathrm{t}, 3 \mathrm{H}, \mathrm{CH}_{3}, \mathrm{~J}=7.1 \mathrm{~Hz}\right)$. Anal. Calcd for $\mathrm{C}_{22} \mathrm{H}_{23} \mathrm{~N}_{3} \mathrm{O}_{7}$ : C, 59.86; H, 5.25; N, 9.52. Found: C, 60.15; H, 5.04; N, 9.36.

Ethyl 4-(2-(4-methoxy-3,5-dimethylphenyl)-2-oxoethyl)-5-oxo-1-phenyl-4,5-dihydro-1H-1,2,4triazole-3-carboxylate (35). Yield 70\%; mp 140-142 ${ }^{\circ} \mathrm{C}(\mathrm{EtOH}) .{ }^{1} \mathrm{H} \mathrm{NMR}\left(\mathrm{CDCl}_{3}\right) 8.04(\mathrm{~d}, 2 \mathrm{H}$, ar, $\mathrm{J}=8.1 \mathrm{~Hz}), 7.71(\mathrm{~s}, 2 \mathrm{H}, \operatorname{ar}), 7.48(\mathrm{t}, 2 \mathrm{H}, \mathrm{ar}, \mathrm{J}=7.9 \mathrm{~Hz}), 7.31(\mathrm{t}, 1 \mathrm{H}$, ar, $\mathrm{J}=7.2 \mathrm{~Hz}), 5.52(\mathrm{~s}, 2 \mathrm{H}$, $\left.\mathrm{CH}_{2}\right), 4.41\left(\mathrm{q}, 2 \mathrm{H}, \mathrm{CH}_{2}, \mathrm{~J}=7.1 \mathrm{~Hz}\right), 3.81\left(\mathrm{~s}, 3 \mathrm{H}, \mathrm{CH}_{3}\right), 2.38\left(\mathrm{~s}, 6 \mathrm{H}, \mathrm{CH}_{3}\right), 1.39\left(\mathrm{t}, 3 \mathrm{H}, \mathrm{CH}_{3}, \mathrm{~J}=7.1\right.$ Hz). Anal. Calcd for $\mathrm{C}_{22} \mathrm{H}_{23} \mathrm{~N}_{3} \mathrm{O}_{5}$ : C, 64.54; H, 5.66; N, 10.26. Found: C, 64.36; H, 5.85; N, 10.08 .

\section{Ethyl 4-(2-(3,5-di-tert-butyl-4-methoxyphenyl)-2-oxoethyl)-5-oxo-1-phenyl-4,5-dihydro-1H-}

1,2,4-triazole-3-carboxylate (36). Yield 60\%; mp 196-198 ${ }^{\circ} \mathrm{C}(\mathrm{EtOH}) .{ }^{1} \mathrm{H} \mathrm{NMR}\left(\mathrm{CDCl}_{3}\right) 8.04$ (d, 2H, ar, J = 7.8 Hz ), $7.94(\mathrm{~s}, 2 \mathrm{H}$, ar), $7.48(\mathrm{t}, 2 \mathrm{H}$, ar, $\mathrm{J}=7.7 \mathrm{~Hz}), 7.32(\mathrm{t}, 1 \mathrm{H}$, ar, J = $7.5 \mathrm{~Hz}), 5.56$ $\left(\mathrm{s}, 2 \mathrm{H}, \mathrm{CH}_{2}\right), 4.42\left(\mathrm{q}, 2 \mathrm{H}, \mathrm{CH}_{2}, \mathrm{~J}=7.1 \mathrm{~Hz}\right), 3.76\left(\mathrm{~s}, 3 \mathrm{H}, \mathrm{CH}_{3}\right), 1.48\left(\mathrm{~s}, 18 \mathrm{H},\left(\mathrm{CH}_{3}\right)_{3}\right), 1.40(\mathrm{t}, 3 \mathrm{H}$, $\mathrm{CH}_{3}, \mathrm{~J}=7.1 \mathrm{~Hz}$ ). Anal. Calcd for $\mathrm{C}_{28} \mathrm{H}_{35} \mathrm{~N}_{3} \mathrm{O}_{5}: \mathrm{C}, 68.13 ; \mathrm{H}, 7.15 ; \mathrm{N}, 8.51$. Found: $\mathrm{C}, 68.36$; $\mathrm{H}$, $6.92 ; \mathrm{N}, 8.74$.

General Procedure for the Synthesis of 1,2,4-Triazolo[4,3-a]pyrazine-3,8(2H,7H)-dione derivatives 37-42. A mixture of the suitable ethyl 1,2,4-triazole-3-carboxylate derivatives 31-36 $(0.9 \mathrm{mmol})$ and anhydrous ammonium acetate $(3.5 \mathrm{mmol})$ was heated in a sealed tube at $140{ }^{\circ} \mathrm{C}$ until the disappearance of starting material (TLC monitoring, 3-24 h). The residue was taken up with $\mathrm{EtOH}(1 \mathrm{~mL})$ and $\mathrm{Et}_{2} \mathrm{O}(5 \mathrm{~mL})$, collected by filtration and washed with water $(20 \mathrm{~mL})$. All the crude compounds were purified by recrystallization.

6-(2,4-Dimethoxyphenyl)-2-phenyl-1,2,4-triazolo[4,3-a]pyrazine-3,8(2H,7H)-dione (37). Yield 64\%; mp 252-254 ${ }^{\circ} \mathrm{C}(\mathrm{AcOH}) .{ }^{1} \mathrm{H}$ NMR (DMSO-d 6 ) 11.34 (br s, $\left.1 \mathrm{H}, \mathrm{NH}\right), 8.00$ (d, 2H, ar, J = 7.7 
Hz), 7.55 (t, 2H, ar, J = 7.6 Hz), 7.33-7.37 (m, 2H, ar), $6.93(\mathrm{~s}, 1 \mathrm{H}, \mathrm{H}-5), 6.67(\mathrm{~d}, 1 \mathrm{H}$, ar, $\mathrm{J}=2.3$ $\mathrm{Hz}), 6.60(\mathrm{dd}, 1 \mathrm{H}$, ar, $\mathrm{J}=2.4,6.1 \mathrm{~Hz}), 3.84\left(\mathrm{~s}, 6 \mathrm{H}, 2 \mathrm{CH}_{3}\right)$. Anal. Calcd for $\mathrm{C}_{19} \mathrm{H}_{16} \mathrm{~N}_{4} \mathrm{O}_{4}$ : C, 62.63; H, 4.43; N, 15.38. Found: C, 62.85; H, 4.25; N, 15.20.

6-(3,4-Dimethoxyphenyl)-2-phenyl-1,2,4-triazolo[4,3-a]pyrazine-3,8(2H,7H)-dione (38). Yield

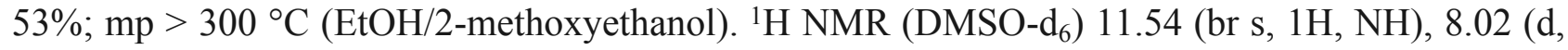
$2 \mathrm{H}, \operatorname{ar}, \mathrm{J}=7.9 \mathrm{~Hz}), 7.56(\mathrm{t}, 2 \mathrm{H}, \mathrm{ar}, \mathrm{J}=7.7 \mathrm{~Hz}), 7.36(\mathrm{t}, 1 \mathrm{H}, \mathrm{ar}, \mathrm{J}=7.4 \mathrm{~Hz}), 7.27-7.29(\mathrm{~m}, 3 \mathrm{H}, 2 \mathrm{ar}+$ H-5), $7.03\left(\mathrm{~d}, 1 \mathrm{H}\right.$, ar, J = 9.0 Hz), $3.87\left(\mathrm{~s}, 3 \mathrm{H}, \mathrm{OCH}_{3}\right), 3.81\left(\mathrm{~s}, 3 \mathrm{H}, \mathrm{OCH}_{3}\right)$. Anal. Calcd for $\mathrm{C}_{19} \mathrm{H}_{16} \mathrm{~N}_{4} \mathrm{O}_{4}: \mathrm{C}, 62.63 ; \mathrm{H}, 4.43 ; \mathrm{N}, 15.38$. Found: C, 62.84; H, 4.36; N, 15.52.

6-(3,4-Methylendioxyphenyl)-2-phenyl-1,2,4-triazolo[4,3-a]pyrazine-3,8(2H,7H)-dione (39). Yield 78\%; mp 279-281 ${ }^{\circ} \mathrm{C}\left(\right.$ AcOH/DMF). ${ }^{1} \mathrm{H}$ NMR (DMSO-d $) 11.53$ (br s, 1H, NH), 8.01 (d, 2H, ar, J = 7.8 Hz) $7.56(\mathrm{t}, 2 \mathrm{H}, \mathrm{ar}, \mathrm{J}=7.7 \mathrm{~Hz}), 7.36(\mathrm{t}, 1 \mathrm{H}, \mathrm{ar}, \mathrm{J}=7.4 \mathrm{~Hz}), 7.30(\mathrm{~d}, 1 \mathrm{H}, \mathrm{ar}, \mathrm{J}=1.6 \mathrm{~Hz})$, 7.20-7.23 (m, 2H, 1 ar, H-5), $7.01(\mathrm{~d}, 1 \mathrm{H}$, ar, $\mathrm{J}=8.2 \mathrm{~Hz}), 6.10\left(\mathrm{~s}, 2 \mathrm{H}, \mathrm{CH}_{2}\right)$. Anal. Calcd for $\mathrm{C}_{18} \mathrm{H}_{12} \mathrm{~N}_{4} \mathrm{O}_{4}: \mathrm{C}, 62.07 ; \mathrm{H}, 3.47 ; \mathrm{N}, 16.09$. Found: C, 62.35; H, 3.25; N, 16.28.

6-(3,4,5-Trimethoxyphenyl)-2-phenyl-1,2,4-triazolo[4,3-a]pyrazine-3,8(2H,7H)-dione (40). Yield 25\%; mp > $300{ }^{\circ} \mathrm{C}(\mathrm{AcOH} / \mathrm{DMF}) .{ }^{1} \mathrm{H}$ NMR $\left(\mathrm{DMSO}_{6}\right) 11.59$ (br s, $\left.1 \mathrm{H}, \mathrm{NH}\right), 8.02$ (d, 2H, ar, $\mathrm{J}=7.7 \mathrm{~Hz}) 7.57(\mathrm{t}, 2 \mathrm{H}$, ar, $\mathrm{J}=7.7 \mathrm{~Hz}), 7.49(\mathrm{~s}, 1 \mathrm{H}, \mathrm{H}-5), 7.37$ (t, 1H, ar, J = 7.4 Hz), 7.02 (s, 2H, ar), $3.89\left(\mathrm{~s}, 6 \mathrm{H}, \mathrm{CH}_{3}\right), 3.70\left(\mathrm{~s}, 3 \mathrm{H}, \mathrm{CH}_{3}\right)$. Anal. Calcd for $\mathrm{C}_{20} \mathrm{H}_{18} \mathrm{~N}_{4} \mathrm{O}_{5}$ : C, 60.91; H, 4.60; N, 14.21. Found: C, 60.75; H, 4.45; N, 14.02.

6-(4-Methoxy-3,5-dimethylphenyl)-2-phenyl-1,2,4-triazolo[4,3-a]pyrazine-3,8(2H,7H)-dione (41). Yield 70\%; mp $>300{ }^{\circ} \mathrm{C}(2-m e t h o x y e t h a n o l / D M F) . ~{ }^{1} \mathrm{H}$ NMR (DMSO-d 6$) 11.48$ (br s, $1 \mathrm{H}$, $\mathrm{NH}), 8.01(\mathrm{~d}, 2 \mathrm{H}$, ar, $\mathrm{J}=7.9 \mathrm{~Hz}), 7.56(\mathrm{t}, 2 \mathrm{H}$, ar, $\mathrm{J}=7.9 \mathrm{~Hz}), 7.44(\mathrm{~s}, 2 \mathrm{H}$, ar), $7.36(\mathrm{t}, 1 \mathrm{H}$, ar, $\mathrm{J}=7.4$ $\mathrm{Hz}), 7.21\left(\mathrm{~s}, 1 \mathrm{H}\right.$, ar), $3.70\left(\mathrm{~s}, 3 \mathrm{H}, \mathrm{CH}_{3}\right), 2.28\left(\mathrm{~s}, 6 \mathrm{H}, \mathrm{CH}_{3}\right)$. Anal. Calcd for $\mathrm{C}_{20} \mathrm{H}_{18} \mathrm{~N}_{4} \mathrm{O}_{3}$ : $\mathrm{C}, 66.29$; H, 5.01; N, 15.46. Found: C, 66.05; H, 5.25; N, 15.35. 


\begin{abstract}
6-(3,5-Di-tert-butyl-4-methoxyphenyl)-2-phenyl-1,2,4-triazolo[4,3-a]pyrazine-3,8(2H,7H)-
dione (42). Yield 75\%; mp $>300^{\circ} \mathrm{C}(\mathrm{AcOH} / \mathrm{DMF}) .{ }^{1} \mathrm{H}$ NMR $\left(\mathrm{DMSO}_{-} \mathrm{d}_{6}\right) 11.63$ (br s, 1H, NH), $8.02(\mathrm{~d}, 2 \mathrm{H}$, ar, $\mathrm{J}=8.2 \mathrm{~Hz}), 7.56(\mathrm{t}, 2 \mathrm{H}$, ar, $\mathrm{J}=7.4 \mathrm{~Hz}), 7.49(\mathrm{~s}, 2 \mathrm{H}$, ar), $7.36(\mathrm{t}, 1 \mathrm{H}$, ar, J = $7.4 \mathrm{~Hz})$, $7.24\left(\mathrm{~s}, 1 \mathrm{H}\right.$, ar), $3.67\left(\mathrm{~s}, 3 \mathrm{H}, \mathrm{CH}_{3}\right), 1.44\left(\mathrm{~s}, 18 \mathrm{H}, 2\left(\mathrm{CH}_{3}\right)_{3}\right)$. Anal. Calcd for $\mathrm{C}_{26} \mathrm{H}_{30} \mathrm{~N}_{4} \mathrm{O}_{3}$ : C, 69.93; H, 6.77; N, 12.55. Found: C, 70.24; H, 6.68; N, 12.37 .
\end{abstract}

General Procedure for the Synthesis of 6-Aryl-8-chloro-2-phenyl-1,2,4-triazolo[4,3-a]pyrazin3-(2H)-ones 43-48. A suspension of the suitable 8-oxo-triazolopyrazine derivatives 37-42 (2.0 mmol) in phosphorus oxychloride $(12 \mathrm{~mL})$ was heated under microwave irradiation at $170{ }^{\circ} \mathrm{C}$ for $1 \mathrm{~h}$ and $30 \mathrm{~min}$. The excess of phosphorus oxychloride was distilled off and the residue was treated with ice and water (about 10-20 mL). The obtained solid was collected by filtration, washed abundantly with water and dried. These intermediates were pure enough (NMR, TLC) to be used for the next step without further purification.

8-Chloro-6-(2,4-dimethoxyphenyl)-2-phenyl-1,2,4-triazolo[4,3-a]pyrazin-3(2H)-one (43). Yield 96\%; ${ }^{1} \mathrm{H}$ NMR (DMSO-d 6 ) 8.34 (s, 1H, H-5), 8.06 (d, 2H, ar, J = 7.8 Hz), $7.92(\mathrm{~d}, 1 \mathrm{H}$, ar, J = 8.6 Hz), 7.58 (t, 2H, ar, J = 7.6 Hz), 7.39 (t, 1H, ar, J = 7.4 Hz), 6.71-6.75 (m, 2H, ar), 3.97 (s, 3H, $\left.\mathrm{CH}_{3}\right), 3.90\left(\mathrm{~s}, 3 \mathrm{H}, \mathrm{CH}_{3}\right)$.

8-Chloro-6-(3,4-dimethoxyphenyl)-2-phenyl-1,2,4-triazolo[4,3-a]pyrazin-3(2H)-one (44). Yield 85\%; ${ }^{1} \mathrm{H}$ NMR (DMSO-d 6 ) 8.63 (s, 1H, H-5), 8.08 (d, 2H, ar, J = 8.1 Hz), 7.62-7.58 (m, 4H, ar), $7.41(\mathrm{t}, 1 \mathrm{H}, \mathrm{ar}, \mathrm{J}=7.4 \mathrm{~Hz}), 7.06(\mathrm{~d}, 1 \mathrm{H}$, ar, J $08.2 \mathrm{~Hz}), 3.88\left(\mathrm{~s}, 3 \mathrm{H}, \mathrm{CH}_{3}\right), 3.81\left(\mathrm{~s}, 3 \mathrm{H}, \mathrm{CH}_{3}\right)$.

8-Chloro-6-(3,4-methylendioxyphenyl)-2-phenyl-1,2,4-triazolo[4,3-a]pyrazin-3(2H)-one Yield 64\%; ${ }^{1} \mathrm{H}$ NMR (DMSO-d $\left.{ }_{6}\right) 8.55$ (s, 1H, H-5), 8.07 (d, 2H, ar, J = $8.0 \mathrm{~Hz}$ ), 7.65 (s, 1H, ar), 7.57-7.59 (m, 3H, ar), 7.40 (t, 1H, ar, J = 7.3 Hz), $7.03\left(\mathrm{~d}, 1 \mathrm{H}\right.$, ar, J = 8.1 Hz), $6.10\left(\mathrm{~s}, 2 \mathrm{H}, \mathrm{CH}_{2}\right)$. 
8-Chloro-6-(3,4,5-trimethoxyphenyl)-2-phenyl-1,2,4-triazolo[4,3-a]pyrazin-3(2H)-one

(46).

Yield 96\%; ${ }^{1} \mathrm{H}$ NMR (DMSO-d $\left.{ }_{6}\right) 8.79(\mathrm{~s}, 1 \mathrm{H}, \mathrm{H}-5), 8.07$ (d, 2H, ar, J = 7.9 Hz), 7.62 (t, 2H, ar, J = $7.8 \mathrm{~Hz}), 7.33$ (s, 2H, ar), 7.41 (t, 1H, ar, J = $7.6 \mathrm{~Hz}), 3.89$ (s, 6H, 2CH 3$), 3.71\left(\mathrm{~s}, 3 \mathrm{H}, \mathrm{CH}_{3}\right)$.

\section{8-Chloro-6-(4-methoxy-3,5-dimethylphenyl)-2-phenyl-1,2,4-triazolo[4,3-a]pyrazin-3(2H)-one} (47). Yield 82\%; ${ }^{1} \mathrm{H}$ NMR (DMSO-d 6 ) 8.48 (s, 1H, ar), 8.07 (d, 2H, ar, J = 8.1 Hz), 7.73 (s, 2H, ar), $7.59(\mathrm{t}, 2 \mathrm{H}$, ar, $\mathrm{J}=7.9 \mathrm{~Hz}), 7.41(\mathrm{t}, 1 \mathrm{H}$, ar, $\mathrm{J}=7.5 \mathrm{~Hz}), 3.70\left(\mathrm{~s}, 3 \mathrm{H}, \mathrm{CH}_{3}\right), 2.30\left(\mathrm{~s}, 6 \mathrm{H}, \mathrm{CH}_{3}\right)$.

\section{8-Chloro-6-(3,5-di-tert-butyl-4-methoxyphenyl)-2-phenyl-1,2,4-triazolo[4,3-a]pyrazin-3(2H)-} one (48). Yield 90\%; ${ }^{1} \mathrm{H}$ NMR (DMSO-d 6 ) 8.65 (s, 1H, ar), 8.07 (d, 2H, ar, J = 7.9 Hz), 7.85 (s, 2H, ar), $7.60(\mathrm{t}, 2 \mathrm{H}$, ar, $\mathrm{J}=7.8 \mathrm{~Hz}), 7.41(\mathrm{t}, 1 \mathrm{H}$, ar, $\mathrm{J}=7.6 \mathrm{~Hz}), 3.67\left(\mathrm{~s}, 3 \mathrm{H}, \mathrm{CH}_{3}\right), 1.45(\mathrm{~s}, 18 \mathrm{H}$, $\left.2\left(\mathrm{CH}_{3}\right)_{3}\right)$.

Molecular Modeling. Refinement of the $h A_{2 A} A R$ and $h A_{1} A R$ Structures. The crystal structure of the $\mathrm{hA}_{2 \mathrm{~A}} \mathrm{AR}$ in complex with ZM241385 was retrieved from the Protein Data Bank (http://www.rcsb.org; pdb code: 5NM4; 1.7- $\AA$ resolution ${ }^{52}$ ) and added of all hydrogen atoms within MOE (Molecular Operating Environment 2014.09). ${ }^{50}$ The crystal structure of the $\mathrm{hA}_{1} \mathrm{AR}$ covalently bound to an antagonist was retrieved from the Protein Data Bank (pdb code: 5N2S; 3.3$\AA$ resolution ${ }^{53}$ ). The structure was prepared for docking studies following analogue protocol as described for the 5NM4 $\mathrm{A}_{2 \mathrm{~A}}$ AR structure.

Molecular docking analysis. All compound structures were docked into the binding site of the AR structures using the Induced Fit docking protocol of MOE and the genetic algorithm docking tool of CCDC Gold..$^{50,51}$ The Induced Fit docking protocol of MOE is divided into a number of stages: Conformational Analysis of ligands. The algorithm generated conformations from a single 3D conformation by conducting a systematic search. In this way, all combinations of angles were created for each ligand. Placement. A collection of poses was generated from the pool of ligand 
conformations using Alpha Triangle placement method. Poses were generated by superposition of ligand atom triplets and triplet points in the receptor binding site. The receptor site points are alpha sphere centers which represent locations of tight packing. At each iteration, a random conformation was selected, a random triplet of ligand atoms and a random triplet of alpha sphere centers were used to determine the pose. Scoring. Poses generated by the placement methodology were scored using the Alpha $H B$ scoring function, which combines a term measuring the geometric fit of the ligand to the binding site and a term measuring hydrogen bonding effects. Induced Fit. The generated docking conformations were subjected to energy minimization within the binding site and the protein sidechains are included in the refinement stage. In detail, the protein backbone is set as rigid while the side chains are not set to "free to move" but are set to "tethered", where an atom tether is a distance restraint that restrains the distance not between two atoms but between an atom and a fixed point in space. Rescoring. Complexes generated by the Induced Fit methodology stage were scored using the Alpha $H B$ scoring function. Gold tool was used with default efficiency settings through MOE interface, by selecting ChemScore as scoring function.

Stability Studies. Chemicals. Acetonitrile (Chromasolv), formic acid (MS grade), tris(hydroxymethyl)aminomethane hydrochloride (Tris $\mathrm{HCl}$ ), verapamil hydrochloride (analytical standard, used as internal standard) and ketoprofen (analytical standard) were purchased by SigmaAldrich (Milan, Italy). Ketoprofen Ethyl Ester (KEE) were obtained by Fisher's reaction from ketoprofen and ethanol. MilliQ water $18 \mathrm{M} \Omega$ was obtained from Millipore's Simplicity system (Milan-Italy). The $50 \mathrm{mM}$ Tris buffer solution was prepared dissolving $0.8 \mathrm{~g}$ of tris(hydroxymethyl)aminomethane hydrochloride in $0.1 \mathrm{~L}$ of MilliQ water. Human plasma was collected from healthy volunteers, pooled and kept at $-80{ }^{\circ} \mathrm{C}$ until use.

Instrumental. The LC-MS/MS analysis was carried out using a Varian 500 MS ion trap system (Palo Alto, CA, USA) equipped by two Prostar 210 pumps, a Prostar 410 autosampler and an 
Electrospray Source (ESI) operating in positive ions. Raw-data were collected and processed by Varian Workstation vers. 6.9 software. G-Therm 015 thermostatic oven was used to maintain the samples at $37{ }^{\circ} \mathrm{C}$ during the test of degradation. ALC micro centrifugette 4214 was employed to centrifuge plasma samples.

The LC-MS/MS parameters, the preparation of the calibration solutions, the linearity of calibration curve and the limit of detection of the quantitative method, for each studied compound, were reported in Supporting Information.

\section{Pharmacology}

Binding Assay. Membrane preparation. Membranes for radioligand binding were prepared as described earlier. ${ }^{27}$ In brief, after homogenization of CHO (Chinese Hamster Ovary) cells stably transfected with hARs or $\mathrm{rA}_{2 \mathrm{~A}} \mathrm{ARs}$, membranes were prepared in a two-step procedure. A first lowspeed step (1000 g), where cell fragments and nuclei were removed, was followed by a high-speed centrifugation $(100000 \mathrm{~g})$ to sediment the crude membrane fraction. The resulting membrane pellets were resuspended in the buffer used for the respective binding experiments $\left(\mathrm{hA}_{1} \mathrm{ARs}: 50 \mathrm{mM}\right.$ Tris/HCl buffer $\mathrm{pH}$ 7.4; $\mathrm{hA}_{2 \mathrm{~A}} / \mathrm{rA}_{2 \mathrm{~A}}$ ARs: $50 \mathrm{mM}$ Tris/HCl, $50 \mathrm{mM} \mathrm{MgCl} 2 \mathrm{pH}$ 7.4; hA 3 ARs: $50 \mathrm{mM}$ Tris/HCl, $10 \mathrm{mM} \mathrm{MgCl}$, $1 \mathrm{mM}$ EDTA, $\mathrm{pH} 8.25)$, frozen in liquid nitrogen, and stored in aliquots at $-80{ }^{\circ} \mathrm{C}$.

Radioligand binding. The affinity of compounds $\mathbf{1 - 2 1}$ for the human AR subtypes, $\mathrm{hA}_{1}, \mathrm{hA}_{2 \mathrm{~A}}, \mathrm{hA_{3 }}$, was determined with radioligand competition experiments in $\mathrm{CHO}$ cells that were stably transfected with the individual receptor subtypes. The radioligands used were $1.0 \mathrm{nM}\left[{ }^{3} \mathrm{H}\right] \mathrm{CCPA}$ ) for $\mathrm{hA}, 10$ $\mathrm{nM}\left[{ }^{3} \mathrm{H}\right] \mathrm{NECA}$ for $\mathrm{hA} \mathrm{A}_{2 \mathrm{~A}} / \mathrm{rA}_{2 \mathrm{~A}}$ and $1.0 \mathrm{nM}\left[{ }^{3} \mathrm{H}\right] \mathrm{HEMADO}$ for $\mathrm{hA}$ receptors. Results were expressed as $\mathrm{K}_{\mathrm{i}}$ values (dissociation constants), which were calculated with the program GraphPad (GraphPAD Software, San Diego, CA, USA). Each concentration was tested three-five times in triplicate and the values are given as the mean \pm standard error (S.E.). 
The potency of antagonists at the $\mathrm{hA}_{2 \mathrm{~B}}$ receptor (expressed on $\mathrm{CHO}$ cells) was determined by inhibition of NECA- stimulated adenylyl cyclase activity.

GloSensor cAMP Assay. Functional $\mathrm{A}_{2 \mathrm{~A}}$ and $\mathrm{A}_{2 \mathrm{~B}}$ activity was determined as described earlier. ${ }^{66,67}$ Briefly, cells stably expressing the $\mathrm{hA}_{2 \mathrm{~A}}$ or $\mathrm{h \textrm {A } _ { 2 \mathrm { B } }} \mathrm{AR}$ and transiently the biosensor, were harvested and incubated in equilibration medium containing a 3\% v/v GloSensor cAMP reagent stock solution, $10 \% \mathrm{FBS}$, and $87 \% \mathrm{CO}_{2}$ independent medium. After $2 \mathrm{~h}$ of incubation at $\mathrm{rt}$, cells were dispensed in the wells of a 384-well plate and NECA reference agonist or the understudy compounds, at different concentrations, were added. When compounds were unable to stimulate the cAMP production they were studied as antagonists. In particular, the antagonist profile was evaluated by assessing the ability of these compounds to counteract NECA-induced increase of cAMP accumulation.

Responses were expressed as percentage of the maximal relative luminescence units (RLU). Concentration-response curves were fitted by a nonlinear regression with the Prism programme. The antagonist profile of the compounds was expressed as $\mathrm{IC}_{50}$, which is the concentration of antagonists that produces $50 \%$ inhibition of the agonist effect. Each concentration was tested threefive times in triplicate and the values are given as the mean \pm S.E. ${ }^{68}$

Microglia Assays. Cell cultures. Primary cultures of microglia were obtained according to the a previously described method. ${ }^{69}$ Briefly, the cerebral cortex of newborn (P1-P3) Sprague-Dawley rats (Harlan, Italy) was dissociated in Hanks' balanced salt solution containing $0.5 \%$ trypsin/EDTA and $1 \%$ DNase (Sigma) for $30 \mathrm{~min}$ at $37^{\circ} \mathrm{C}$. The suspension was mechanically homogenized and filtered. Cells were plated in high-glucose DMEM with 20\% FBS. Confluent primary microglia cultures were used to isolate microglia by shaking. The purity of microglia cultures was determined immunocytochemically by staining for Ibal (Wako, Italy). Cells were fixed in $4 \%$ paraformaldehyde, then incubated with the antibody (1:200), and visualized using Alexa Fluorconjugated secondary antibody. Nuclei were stained with 4,6-diamidino-2-phenylindole 
dihydrochloride. Iba1-positive cells were $95-98 \%$ in microglia cultures. Experiments were performed 10 days after cell isolation. Formal approval to conduct the experiments described was obtained from the Animal Subjects Review Board of the University of Florence.

Cell viability assay. Cell viability was evaluated by the reduction of 3-(4,5-dimethylthiazol-2-yl)2,5-diphenyltetrazolium bromide (MTT) as an index of mitochondrial compartment functionality. After treatments and an extensive washing, $1 \mathrm{mg} / \mathrm{ml}$ MTT was added into each well and incubated for $2 \mathrm{~h}$ at $37^{\circ} \mathrm{C}$. After washing, the formazan crystals were dissolved in $100 \mu$ dimethyl sulfoxide. The absorbance was measured at $580 \mathrm{~nm}$. Experiments were performed in quadruplicate on at least three different cell batches.

Superoxide dismutase (SOD)-inhibitable superoxide anion $\left(\mathrm{O}_{2} \cdot^{-}\right)$production evaluation by cytochrome $C$ assay. Microglia was plated in six-well plates $\left(5 \times 10^{5} /\right.$ well $)$ and grown until confluent. Cells were then incubated with or without $100 \mu \mathrm{M}$ oxaliplatin in serum-free DMEM containing cytochrome $\mathrm{C}(1 \mathrm{mg} / \mathrm{ml})$ for $4 \mathrm{~h}$ at $37^{\circ} \mathrm{C}$, in the absence or presence of $10 \mu \mathrm{M}$ tested compounds. Nonspecific cytochrome $C$ reduction was evaluated by carrying out tests in the presence of bovine SOD $(300 \mathrm{mU} / \mathrm{ml})$. The supernatants were collected, and the optical density was spectrophotometrically measured at $550 \mathrm{~nm}$. After the nonspecific absorbance was subtracted, the SOD-inhibitable $\mathrm{O}_{2} \cdot^{-}$amount was calculated by using an extinction coefficient of $2.1 \times 10^{4} \mathrm{M}^{-1}$ $\mathrm{cm}^{-1}$ and expressed as $\mu \mathrm{M} / \mathrm{mg}$ protein/4 $\mathrm{h}$. The $4 \mathrm{~h}$ incubation interval was chosen on the basis of preliminary experiments, which showed poor reliability for longer cytochrome $c$ exposure to the cellular environment. 
Catalase activity. Enzymatic activity was measured in microglia culture. After incubation and treatments, cells were washed once with PBS and scraped with PBS on ice. Cells were then collected, subjected to a freeze-thaw cycle and centrifuged $\left(13,000 \times \mathrm{g}\right.$ for $10 \mathrm{~min}$ at $\left.4{ }^{\circ} \mathrm{C}\right)$. Catalase activity was measured in the supernatant by Amplex Red Catalase Assay Kit (Invitrogen, Monza, Italy) following the manufacturer's instructions. Protein concentration was quantified by bicinchoninic acid assay (Sigma-Aldrich, Milan, Italy). Catalase activity for each sample was normalized to protein concentration. Control conditions in the absence of treatment were set as $100 \%$

In vivo tests. Animals. Male CD-1 albino mice (Envigo, Varese, Italy) weighing approximately 22$25 \mathrm{~g}$ at the beginning of the experimental procedure, were used. Animals were housed in Ce.S.A.L (Centro Stabulazione Animali da Laboratorio, University of Florence) and used at least 1 week after their arrival. Ten mice were housed per cage $($ size $26 \times 41 \mathrm{~cm})$. Animals were fed a standard

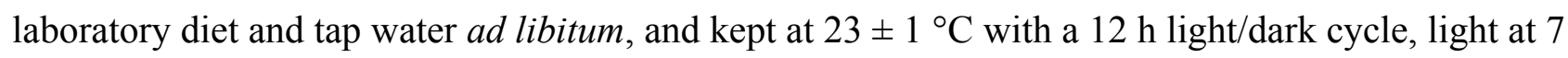
a.m. All animal manipulations were carried out according to the Directive 2010/63/EU of the European parliament and of the European Union council (22 September 2010) on the protection of animals used for scientific purposes. The ethical policy of the University of Florence complies with the Guide for the Care and Use of Laboratory Animals of the US National Institutes of Health (NIH Publication No. 85-23, revised 1996; University of Florence assurance number: A5278-01). Formal approval to conduct the experiments described was obtained from the Animal Subjects Review Board of the University of Florence. Experiments involving animals have been reported according to ARRIVE guideline. All efforts were made to minimize animal suffering and to reduce the number of animals used.

Oxaliplatin-induced neuropathic pain model and pharmacological treatments. Mice treated with oxaliplatin (2.4 mg kg-1) were administered intraperitoneally (i.p.) on days 1-2, 5-9, $12-14$ (10 i.p. 
injections).$^{70}$ Oxaliplatin was dissolved in $5 \%$ glucose solution. Control animals received an equivalent volume of vehicle. Behavioural tests were performed on day 14. Tested compounds were suspended in 1\% carboxymethylcellulose sodium salt (CMC, Sigma-Aldrich, Milan, Italy) and per os (p.o.) acutely administered.

Cold plate test. The animals were placed in a stainless steel box $(12 \mathrm{~cm} \times 20 \mathrm{~cm} \times 10 \mathrm{~cm})$ with a cold plate as floor. The temperature of the cold plate was kept constant at $4{ }^{\circ} \mathrm{C} \pm 1{ }^{\circ} \mathrm{C}$. Pain-related behaviour (licking of the hind paw) was observed and the time (seconds) of the first sign was recorded. The cut-off time of the latency of paw lifting or licking was set at $60 \mathrm{~s} .{ }^{71,72}$

Statistical analysis. Behavioural measurements were performed on 12 mice for each treatment carried out in 2 different experimental sets. Results were expressed as mean \pm S.E.M. The analysis of variance of behavioural data was performed by one way ANOVA, a Bonferroni's significant difference procedure was used as post-hoc comparison. $P$ values of less than 0.05 or 0.01 were considered significant. Investigators were blind to all experimental procedures. Data were analysed using the "Origin 9" software (OriginLab, Northampton, USA).

\section{SUPPORTING INFORMATION}

-Stability Studies.

-Molecular formula strings (CSV).

-PDB coordinates of the $3 \mathrm{D}$ structure of the $\mathrm{hA}_{2 \mathrm{~A}}$ adenosine receptor (PDB code $5 \mathrm{NM} 4$ ) and $\mathrm{hA}_{1}$ adenosine receptor (PDB code 5N2S). The two structures were added to hydrogen atoms and missing loop segments and energetically minimized.

Authors will release the atomic coordinates upon article publication. 
ACKNOWLEDGMENTS. The work was financially supported by the Italian Ministry for University and Research (MIUR, PRIN 2010-2011, 20103W4779_004 project), the University of Florence (Fondi Ateneo Ricerca) and Fondazione Cassa di Risparmio di Firenze (2018).

\begin{abstract}
ABBREVIATIONS USED
AR, adenosine receptor; BHT, 3,5-ditert-butyl-4-hydroxytoluene; CHO, chinese hamster ovary; CCPA, 2-chloro-N6-cyclopentyladenosine; CMC, carboxymethylcellulose; DMME, Dulbecco's modified Eagle's medium; EL, extracellular loop; FBS, fetal bovine serum; HEMADO, (2-(1hexynyl)-N-methyladenosine; KEE, ketoprofene ethylester; MOE, molecular operating environment; MTT, 3-(4,5-dimethylthiazol-2-yl)-2,5-diphenyltetrazolium bromide; mw, microwave; NECA, 5'-(N-ethyl-carboxamido)adenosine; RMS, root mean square; SOD, superoxide dismutase; TM, transmembrane
\end{abstract}

\title{
REFERENCES
}

1. Borea, P.A.; Gessi S.; Merighi, S.; Vincenzi, F.; Varani, K. Pharmacology of Adenosine Receptors: the State of Art. Physiol. Rev. 2018, 98, 1591-1625.

2. van Waarde, A.; Dierckx, R. A.J.O.; Zhou, X.; Khanapur, S.; Tsukada, H.; Ishiwata, K.; Luurtsema, G.; de Vries, E.F.J.; Elsinga, P.H. Potential Therapeutic Applications of Adenosine $\mathrm{A}_{2 \mathrm{~A}}$ Receptor Ligands and Opportunities for $\mathrm{A}_{2 \mathrm{~A}}$ Receptor Imaging. Med. Res. Rev. 2018, 38, 5-56.

3. Borea, P.A.; Gessi S.; Merighi S.; Varani, K. Adenosine as Multi-Signalling Guardian Angel in Human Diseases: When, Where and How Does it Exert its Protective Effects?. Trends Pharmacol. Sci. 2016, 37, 419-434. 
4. Stockwell, J.; Jakova E.; Cayabyab, F.S. Adenosine $\mathrm{A}_{1}$ and $\mathrm{A}_{2 \mathrm{~A}}$ Receptors in the Brain: Current Research and their Role in Neurodegeneration. Molecules, 2017, 22, 676.

5. Borea P.A.; Gessi, S.; Merighi, S.; Vincenzi, F.; Varani, K. Pathological Overproduction: the Bad Side of Adenosine. Br. J. Pharmacol. 2017 174, 1945-1960.

6. Hasko, G.; Pacher, P.; Vizi, E.S.; Illes, P. Adenosine Receptor Signaling in the Brain Immune System. Trends Pharmacol. Sci. 2005, 26, 511-516.

7. Martín, E.D.; Fernández, M.; Perea, G.; Pascual, O.; Haydon, P.G.; Araque, A.; Ceña, V. Adenosine Released by Astrocytes Contributes to Hypoxia-Induced Modulation of Synaptic Transmission. Glia 2007, 55, 36-45.

8. Gomes, C.; Ferreira, R.; George, J.; Sanches, R.; Rodrigues, D.I.; Gonçalves, N.; Cunha, R.A. Activation of Microglial Cells Triggers a Release of Brain-Derived Neurotrophic Factor (BDNF) Inducing their Proliferation in an Adenosine $\mathrm{A}_{2 \mathrm{~A}}$ Receptor-Dependent Manner: $\mathrm{A}_{2 \mathrm{~A}}$ Receptor Blockade Prevents BDNF Release and Proliferation of Microglia. J. Neuroinflammation 2013, 10, 16.

9. Santiago, A.R.; Baptista, F.I.; Santos, P.F.; Cristovao, G.; Ambrosio, A.F.; Cunha, R.A.; Gomes, C.A. Role of Microglia Adenosine $\mathrm{A}_{2 \mathrm{~A}}$ Receptors in Retinal and Brain Neurodegenerative Diseases. Mediators of Inflammation 2014, ID 465694, 13 page.

10. Pintor, A.; Quarta, D.; Pèzzola, A.; Reggio, R.; Popoli, P. SCH 58261 an Adenosine A(2A) Receptor Antagonist Reduces, only at Low Doses, $\mathrm{K}(+)$-Evoked Glutamate Release in the Striatum. Eur. J. Pharmacol. 2001, 421, 177-180.

11. Popoli, P.; Pintor, A.; Domenici, M.R.; Frank, C.; Tebano, M.T.; Pèzzola, A.; Scarchilli, L.; Quarta, D.; Reggio, R.; Malchiodi-Albedi, F.; Falchi, M.; Massotti, M. Blockade of Striatal Adenosine $\mathrm{A}_{2 \mathrm{~A}}$ Receptor Reduces, through a Presynaptic Mechanism, Quinolinic AcidInduced Excitotoxicity: Possible Relevance to Neuroprotective Interventions in Neurodegenerative Diseases of the Striatum. J. Neurosci. 2002, 22, 1967-1975. 
12. Pedata, F.; Dettori, I.; Coppi, E.; Melani, A.; Fusco, I.; Corradetti, R.; Pugliese, A.M. Purinergic Signalling in Brain Ischemia. Neuropharmacology 2016, 104, 105-130.

13. Nishizaki, T.; Nagai, K.; Nomura, T.; Tada, H.; Kanno, T.; Tozaki, H.; Li, X.X.; Kondoh, T.; Kodama, N.; Takahashi, E.; Sakai, N.; Tanaka, K.; Saito, N. A New Neuromodulatory Pathway with a Glial Contribution Mediated via A(2A) Adenosine Receptors. Glia 2002, $39,133-147$.

14. Nishizaki, T. ATP- and Adenosine-mediated Signaling in the Central Nervous System: Adenosine Stimulates Glutamate Release from Astrocytes via $\mathrm{A}_{2 \mathrm{~A}}$ Adenosine Receptors. $J$. Pharmacol. Sci. 2004, 94, 100-102.

15. Bura, S. A.; Nadal, X.; Ledent, C.; Maldonado, R.; Valverde, O. A $\mathrm{A}_{2 \mathrm{~A}}$ Adenosine Receptor Regulates Glia Proliferation and Pain after Peripheral Nerve Injury. Pain 2008, 140, 95-103.

16. Zhuo, M. Neuronal Mechanism for Neuropathic Pain. Mol. Pain 2007, 3, 14.

17. Kim, H.K.; Park, S.K.; Zhou, J.L.; Taglialatela, G.; Chung, K.; Coggeshall, R.E.; Chung J.M. Reactive Oxygen Species (ROS) Play an Important Role in Rat Model of Neuropathic Pain. Pain 2004, 111, 116-124.

18. Naik, A.K.; Tandan, S.K.; Dudhgaonkar, S.P.; Jadhav, S.H.; Kataria, M.; Prakash, V.R. Kumar, D. Role of Oxidative Stress in Pathophysiology of Peripheral Neuropathy and Modulation by N-acetyl-L-cysteine in Rats. Eur. J. Pain 2006, 10, 573-579.

19. Areti, A.; Ganesh, Y.V.; Naidu, V.G.M.; Kumar, A. Oxidative Stress and Nerve Damage: Role in Chemotherapy Induced Peripheral Neuropathy. Redox Biology 2014, 2, 289-295.

20. Carrasco, C.; Naziroğlu, M.; Rodríguez, A.B.; Pariente, J.A. Neuropathic Pain: Delving into the Oxidative Origin and the Possible Implication of Transient Receptor Potential Channels. Front. Physiol. 2018, 9, 95.

21. Sawynok, J. Adenosine Receptor Targets for Pain. Neuroscience 2016, 338, 1-18. 
22. Godfrey, L.; Yan, L.; Clarke, G.D.; Ledent, C.; Kitchen, I.; Hourani, S.M.O. Modulation of Paracetamol Antinociception by Caffeine and Selective Adenosine $\mathrm{A}_{2}$ Receptor Antagonists in Mice. Eur. J. Pharmacol. 2006, 531, 80-86.

23. Hussey, M.J.; Clarke, G.D.; Ledent, C.; Hourani, S.M.O.; Kitchen, I. Reduced Response to the Formalin Test and Lowered Spinal NMDA Glutamate Receptor Binding in Adenosine $\mathrm{A}_{2 \mathrm{~A}}$ Receptor Knockout Mice. Pain 2007, 129, 287-294.

24. Sawynok, J.; Reid, A.R. Caffeine Inhibits Antinociception by Acetaminophen in the Formalin Test by Inhibiting Spinal Adenosine $\mathrm{A}_{1}$ Receptors. Eur. J. Pharmacol. 2012, 674, $248-254$.

25. Varano, F.; Catarzi, D.; Vincenzi, F.; Betti, M.; Falsini, M.; Ravani, A.;Borea, P.A.; Colotta, V.; Varani, K. Design, Synthesis, and Pharmacological Characterization of 2 - (2Furanyl)thiazolo[5,4- $d$ ]pyrimidine-5,7-diamine Derivatives: New Highly Potent $\mathrm{A}_{2 \mathrm{~A}}$ Adenosine Receptor Inverse Agonists with Antinociceptive Activity. J. Med. Chem. 2016, 59, 10564-10576.

26. Squarcialupi, L.; Betti, M.; Catarzi, D.; Varano, F.; Falsini, M.; Ravani, A.; Pasquini, S.; Vincenzi, F.; Salmaso, V.; Sturlese, M.; Varani, K.; Moro, S.; Colotta V. The Role of 5Arylalkylamino- and 5-Piperazino- Moieties on the 7-Aminopyrazolo[4,3- $d]$ pyrimidine Core in Affecting Adenosine $\mathrm{A}_{1}$ and $\mathrm{A}_{2 \mathrm{~A}}$ Receptor Affinity and Selectivity Profiles. J. Enz. Inhib. Med. Chem. 2017, 32, 248-263.

27. Falsini, M.; Squarcialupi, L.; Catarzi, D.; Varano, F.; Betti, M.; Dal Ben, D.; Marucci, G.; Buccioni, M.; Volpini, R.; De Vita, T.; Cavalli, A.; Colotta, V. The 1,2,4-Triazolo[4,3a]pyrazin-3-one as a Versatile Scaffold for the Design of Potent Adenosine Human Receptor Antagonists. Structural Investigations to Target the $\mathrm{A}_{2 \mathrm{~A}}$ Receptor. J. Med. Chem. 2017, 60, $5772-5790$. 
28. Gessi, S.; Bencivenni, S.; Battistello, E.; Vincenzi, F.; Colotta, V.; Catarzi, D.; Varano, F.; Merighi, S.; Borea, P.A.; Varani, V. Inhibition of $\mathrm{A}_{2 \mathrm{~A}}$ Adenosine Receptor Signaling in Cancer Cells Proliferation by the Novel Antagonist TP455. Front. Pharmacol. 2017, 8, 888. 29. Catarzi, D.; Varano, F.; Falsini, M.; Varani, K.; Vincenzi, F.; Colotta, V. Development of Novel Pyridazinone-based Adenosine Receptor Ligands. Bioorg. Med. Chem. Lett. 2018, 28, 1484-1489.

30. Varano, F.; Catarzi, D.; Falsini, M.; Vincenzi, F.; Pasquini, S.; Varani, K.; Colotta, V. Identification of Novel Thiazolo[5,4-d]pyrimidine Derivatives as Human $\mathrm{A}_{1}$ and $\mathrm{A}_{2 \mathrm{~A}}$ Adenosine Receptor Antagonists/Inverse Agonists. Bioorg. Med. Chem. 2018, 26, 36883695.

31. Varano, F.; Catarzi, D.; Vincenzi, F.; Falsini, M.; Pasquini, S.; Borea, P.A.; Colotta, V.; Varani, K. Structure-Activity Relationship Studies and Pharmacological Characterization of N5-Heteroarylalkyl-substituted-2-(2-furanyl)thiazolo[5,4-d]pyrimidine-5,7-diamine-based Derivatives as Inverse Agonists at Human $\mathrm{A}_{2 \mathrm{~A}}$ Adenosine Receptor. Eur. J. Med. Chem. 2018, $155,552-561$.

32. Varano, F.; Catarzi, D.; Falsini, M.; Dal Ben, D.; Buccioni, M.; Marucci, G.; Volpini, R.; Colotta, V. Novel Human Adenosine Receptor Antagonists Based on the 7-Aminothiazolo[5,4-d]pyrimidine Scaffold. Structural Investigations at the 2-, 5- and 7-Positions to Enhance Affinity and Tune Selectivity. Bioorg. Med. Chem. Lett. 2019, 29, 563-569.

33. Falsini, M.; Catarzi, D.; Varano, F.; Dal Ben, D.; Marucci, G.; Buccioni, M.; Volpini, R.; Di Cesare Mannelli, L. Ghelardini, C.; Colotta, V. Novel 8-Amino-1,2,4-triazolo[4,3-a]pyrazin3-one Derivatives as Potent Human Adenosine $\mathrm{A}_{1}$ and $\mathrm{A}_{2 \mathrm{~A}}$ Receptor Antagonists. Evaluation of Their Protective Effect against $\beta$-Amyloid-induced Neurotoxicity in SHSY5Y Cells. Bioorg. Chem. 2019, 87, 380-394. 
34. Betti, M.; Catarzi, D.; Varano, F.; Falsini, M.; Varani, K.; Vincenzi, F.; Dal Ben, D.; Lambertucci, C.; Colotta, V. The Aminopyridine-3,5-Dicarbonitrile Core for the Design of New non-Nucleoside-like Agonists of the Human Adenosine $\mathrm{A}_{2 \mathrm{~B}}$ Receptor. Eur. J. Med. Chem. 2018, 150, 127-139.

35. Bonsack, F.; Cargill, H.; Alleyne J.R.; Sukumari-Ramesh, S. Resveratrol Attenuates Neurodegeneration and Improves Neurological Outcomes after Intracerebral Hemorrhage in Mice. Front. Cell. Neurosci. 2017, 11, 228.

36. Gay, N.H.; Phopin, K.; Suwanjang, W.; Songtawee, N, Ruankham, W.; Wongchitrat, P.; Prachayasittikul, S.; Prachayasittikul, V. Neuroprotective Effects of Phenolic and Carboxylic Acids on Oxidative Stress-Induced Toxicity in Human Neuroblastoma SHSY5Y. Cells Neurochem. Res. 2018, 43, 619-636.

37. Benfeito, S.; Oliveira, C.; Soares, P.; Fernandes, C.; Silva, T.; Teixeira, J.; Borges, F. Antioxidant Therapy: Still in Search of the "Magic Bullet". Mitochondrion 2013, 13, $427-435$.

38. Yehye, W.A.; Rahman, N.A.; Ariffin, A.; Abd Hamid, S.B.; Alhadi, A.A.; Kadir, F.A.; Yaeghoobi, M. Understanding the Chemistry behind the Antioxidant Activities of Butylated Hydroxytoluene (BHT): a Review. Eur. J. Med. Chem. 2015, 101, 295-312.

39. Seifar, F.; Khalili, M.; Khaledyan, H.; Amiri Moghadam, S.; Izadi, A.; Azimi, A.; Shakouri S.K. $\alpha$-Lipoic Acid, Functional Fatty Acid, as a Novel Therapeutic Alternative for Central Nervous System Diseases: A Review. Nutr. Neurosci. 2019, 22, 306-312.

40. Molz, P.; Schröder, N. Potential Therapeutic Effects of Lipoic Acid on Memory Deficits Related to Aging and Neurodegeneration. Front. Pharmacol. 2017, 8, 849.

41. Mostacci, B.; Liguori, R.; Cicero, A.F.G. Nutraceutical Approach to Peripheral Neuropathies: Evidence from Clinical Trials. Curr. Drug Metab. 2018, 19, 460-468. 
42. Papanas, N.; Ziegler, D. Efficacy of $\alpha$-Lipoic Acid in Diabetic Neuropathy. Expert Opin. Pharmacother. 2014, 15, 2721-2731.

43. Agathos, E.; Tentolouris, A.; Eleftheriadou, I.; Katsaouni, P.; Nemtzas, I.; Petrou, A.; Papanikolaou, C.; Tentolouris, N. Effect of $\alpha$-Lipoic Acid on Symptoms and Quality of Life in Patients with Painful Diabetic Neuropathy. J. Int. Med. Res. 2018, 46, 1779-1790.

44. Matiychuk, V.S.; Potopnyk, M.A.; Luboradzki, R.; Obushak, M.D. A New Method for the Synthesis of 1-Aryl-1,2,4-triazole Derivatives. Synthesis, 2011, 11, 1799-1803.

45. Al-Rifai, N.; Rucker, H.; Amslinger, S. Opening or Closing the Lock? When Reactivity is the Key to Biological Activity. Chem. Eur. J. 2013, 19, 15384-15395.

46. Boulahjar, R.; Rincon Arias, A.; Bolteau, R.; Renault, N.; Coevoet, M.; Barczyk, A.;

Duroux, R.; Yous, S.; Melnyk, P.; Agouridas, L. Design and Synthesis of 2,6-Disubstituted8-Amino-Imidazo[1,2-a]Pyridines, a Promising Privileged Structure. Bioorg. Med. Chem. 2018, 26, 3296-3307.

47. Moine, E.; Dimier-Poisson I.; Enguehard-Gueiffier, C.; Logè, C.; Penichon, M.; Moirè, N.; Delehouzè, C.; Foll-Josselin, B.; Ruchaud, S.; Bach, S.; Gueiffier, A.; Debierre-Grockiego, F.; Denevault-Sabourin, C. Development of New Highly Potent Imidazo[1,2-b]pyridazines Targeting Toxoplasma Gondii Calcium-Dependent Protein Kinase 1. Eur. J. Med. Chem. 2015, 105, 80-105.

48. Fan, Y.; Luo, Y.; Ma, C. Synthesis and Cytotoxic Evaluation of Combretastatin A-4 Analogues of Benzo[b]Furans. Monatsh. Chem. 2017, 148, 1823-1832.

49. Nishinaga, A.; Shimizu, T.; Toyoda, Y.; Matsuura, T. Oxygenation of 2,6-di-TertButylphenols Bearing an Electron-Withdrawing Group in the 4-Position, J. Org. Chem. 1982, 47, 2278-2285.

50. Molecular Operating Environment; C.C.G., I., 1255 University St., Suite 1600, Montreal, Quebec, Canada, H3B 3X3. 
51. Jones, G.; Willett, P.; Glen, R.C.; Leach, A.R.; Taylor, R. Development and Validation of a Genetic Algorithm for Flexible Docking. J. Mol. Biol. 1997, 267, 727-748.

52. Weinert, T.; Olieric, N.; Cheng, R.; Brunle, S.; James, D.; Ozerov, D.; Gashi, D.; Vera, L.; Marsh, M.; Jaeger, K.; Dworkowski, F.; Panepucci, E.; Basu, S.; Skopintsev, P.; Dore, A. S.; Geng, T.; Cooke, R.M.; Liang, M.; Prota, A.E.; Panneels, V.; Nogly, P.; Ermler, U.; Schertler, G.; Hennig, M.; Steinmetz, M.O.; Wang, M.; Standfuss, J. Serial Millisecond Crystallography for Routine Room-Temperature Structure Determination at Synchrotrons. Nat. Commun 2017, 8, 542.

53. Cheng, R.K.Y.; Segala, E.; Robertson, N.; Deflorian, F.; Dore, A.S.; Errey, J.C.; FiezVandal, C.; Marshall, F.H.; Cooke, R.M. Structures of Human $\mathrm{A}_{1}$ and $\mathrm{A}_{2 \mathrm{~A}}$ Adenosine Receptors with Xanthines Reveal Determinants of Selectivity. Structure 2017, 25, 1275 1285 e4.

54. Jaakola, V.P.; Griffith, M.T.; Hanson, M.A.; Cherezov, V.; Chien, E.Y.; Lane, J.R.; IJzerman, A.P.; Stevens, R. C. The 2.6 Angstrom Crystal Structure of a Human $\mathrm{A}_{2 \mathrm{~A}}$ Adenosine Receptor Bound to an Antagonist. Science 2008, 322, 1211-1217.

55. Dal Ben, D.; Lambertucci, C.; Marucci, G.; Volpini, R.; Cristalli, G. Adenosine Receptor Modeling: What does the $\mathrm{A}_{2 \mathrm{~A}}$ Crystal Structure Tell Us? Curr. Top. Med. Chem. 2010, 10, 993-1018.

56. Gamelin, E.; Gamelin, L.; Bossi, L.; Quasthoff, S. Clinical Aspects and Molecular Basis of Oxaliplatin Neurotoxicity: Current Management and Development of Preventive Measures. Semin. Oncol. 2002, 29, Suppl 5, 21-33.

57. Di Cesare Mannelli, L.; Pacini, A.; Bonaccini, L.; Zanardelli, M.; Mello, T.; Ghelardini, C. Morphologic Features and Glial Activation in Rat Oxaliplatin-Dependent Neuropathic Pain. J. Pain 2013, 14, 1585-1600. 
58. Di Cesare Mannelli, L.; Pacini, A.; Micheli, L.; Tani, A.; Zanardelli, M.; Ghelardini, C. Glial Role in Oxaliplatin-Induced Neuropathic Pain. Exp. Neurol. 2014, 261, 22-33.

59. Di Cesare Mannelli, L., Zanardelli, M.; Failli, P.; Ghelardini, C. Oxaliplatin-Induced Neuropathy: Oxidative Stress as Pathological Mechanism. Protective Effect of Silibinin. $J$. Pain 2012, 13, 276-284.

60. Di Cesare Mannelli, L.; Zanardelli, M.; Failli, P.; Ghelardini, C. Oxaliplatin-Induced Oxidative Stress in Nervous System-Derived Cellular Models: Could It Correlate with in vivo Neuropathy? Free Radic. Biol. Med. 2013, 6, 143-150.

61. Zanardelli, M.; Micheli, L.; Cinci, L.; Failli, P.; Ghelardini, C.; Di Cesare Mannelli, L. Oxaliplatin Neurotoxicity Involves Peroxisome Alterations. PPAR $\gamma$ Agonism as Preventive Pharmacological Approach. PLoS One 2014, 9, e102758.

62. Connell, B.J.; Saleh, M.C.; Khan, B.V.; Rajagopal, D.; Saleh, T.M., UPEI-100, a Conjugate of Lipoic Acid and Apocynin Mediates Neuroprotection in a Rat Model of Ischemia/Reperfusion. Am. J. Physiol. Regul. Integr. Comp. Physiol. 2012, 302, R886-R895. 63. Saleh, M.C.; Connell, B.J.; Rajagopal, D.; Khan, B.V.; Abd-El-Aziz, A.S.; Kucukkaya, I., Saleh, T. M., Co-administration of Resveratrol and Lipoic Acid or Their Synthetic Combination, Enhances Neuroprotection in a Rat Model of Ischemia/Reperfusion. PLoS One 2014, 9, 1-9.

64. Teodori, E., Dei, S., Bartolucci, G., Perrone, M.G., Manetti, D., Romanelli, M.N., Contino, M., Colabufo, N.A. Structure-Activity Relationship Studies on 6,7-Dimethoxy-2-phenethyl1,2,3,4-tetrahydroisoquinoline Derivatives as Multidrug Resistance Reversers. Chem. Med. Chem. 2017, 12, 1369-1379.

65. Marshall, A.G.; Hendrickson, C.L. High-resolution Mass Spectrometers. Annu. Rev. Anal. Chem. 2008, 1, 579-599. 
66. Thomas, A.; Buccioni, M.; Dal Ben, D.; Lambertucci, C.; Marucci, G.; Santinelli, C.; Spinaci, A.; Kachler, S.; Klotz, K.- N.; Volpini, R. The Length and Flexibility of the 2Substituent of 9-Ethyladenine Derivatives Modulate Affinity and Selectivity for the Human $\mathrm{A}_{2 \mathrm{~A}}$ Adenosine Receptor. Chem. Med. Chem. 2016, 11, 1829-1839.

67. Buccioni, M.; Santinelli, C.; Angeli, P.; Dal Ben, D.; Lambertucci, C.; Thomas, A.; Volpini, R.; Marucci, G. Overview on Radiolabel-Free in vitro Assays for GPCRs. Mini Rev. Med. Chem. 2017, 17, 3-14.

68. Buccioni, M.; Marucci, G.; Dal Ben, D.; Giacobbe, D.; Lambertucci, C.; Soverchia, L.; Thomas, A.; Volpini, R.; Cristalli, G. Innovative Functional cAMP Assay for Studying G Protein-Coupled Receptors: Application to the Pharmacological Characterization of GPR17. Purinerg. Signal. 2011, 7, 463-468.

69. McCarty, K.D.; de Vellis, J. Preparation of Separate Astroglial and Oligodendroglial Cell Cultures from Rat Cerebral Tissue. J. Cell. Biol. 1980, 85, 890-902.

70. Di Cesare Mannelli, L.; Lucarini, E.; Micheli, L.; Mosca, I.; Ambrosino, P.; Soldovieri, M.V.; Martelli, A.; Testai, L.; Taglialatela, M.; Calderone, V.; Ghelardini, C. Effects of Natural and Synthetic Isothiocyanate-based $\mathrm{H}_{2} \mathrm{~S}$-Releasers Against Chemotherapy-Induced Neuropathic Pain: Role of Kv7 Potassium Channels. Neuropharmacology 2017, 121, 49-59.

71. Di Cesare Mannelli, L.; Bani, D.; Bencini, A.; Brandi, M.L.; Calosi, L.; Cantore, M.; Carossino, A.M.; Ghelardini, C.; Valtancoli, B.; Failli, P. Therapeutic Effects of the Superoxide Dismutase Mimetic Compound MnIIMe2DO2A on Experimental Articular Pain in Rats. Mediators Inflamm. 2013, ID 905360.

72. Failli, P.; Bani, D.; Bencini, A.; Cantore, M.; Di Cesare Mannelli, L.; Ghelardini, C.; Giorgi, C.; Innocenti, M.; Rugi, F.; Spepi, A.; Udisti, R.; Valtancoli, B. A Novel Manganese Complex Effective as Superoxide Anion Scavenger and Therapeutic Agent Against Cell and Tissue Oxidative Injury. J. Med. Chem. 2009, 52, 7273-7283. 


\section{Table of Contents Graphic}

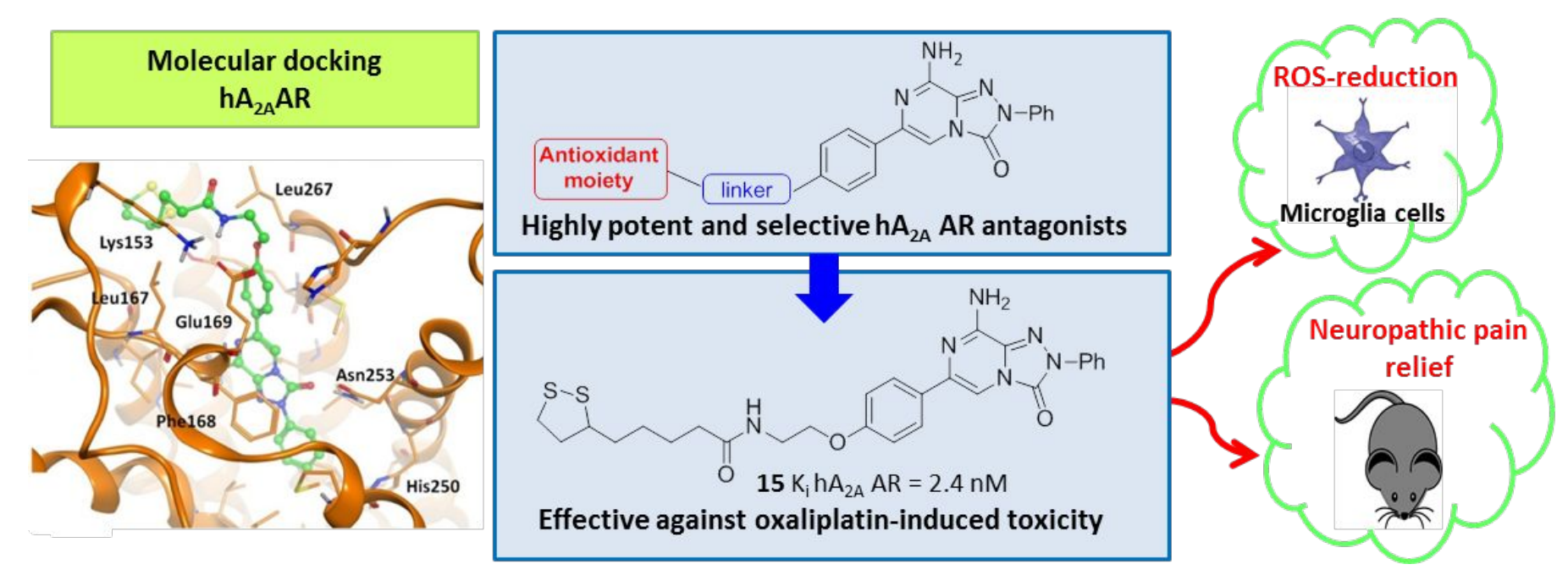

